\title{
Emmi Sarvikivi
}

\section{Healthcare-Associated Infections in Pediatrics}

Publications of the National Public Health Institute A $11 / 2008$

Department of Infectious Disease

Epidemiology and Control

National Public Health Institute

and

Pediatric Graduate School

Hospital for Children and Adolescents

University of Helsinki, Finland 



\title{
HEALTHCARE-ASSOCIATED INFECTIONS IN PEDIATRICS
}

\author{
A C A D E M I C D I S S E R T A T I O N \\ To be presented with the permission of the Medical Faculty, University of Helsinki, \\ for public examination in Niilo Hallman Auditorium, \\ Hospital for Children and Adolescents, Stenbäckinkatu 11, \\ on May 9, 2008, at 12 noon.
}

Pediatric Graduate School, Hospital for Children and Adolescents,

University of Helsinki, Finland and

Department of Infectious Disease Epidemiology and Control, National Public Health Institute,

Helsinki, Finland

Helsinki 2008 
Publications of the National Public Health Institute KTLA 11 / 2008

Copyright National Public Health Institute

Julkaisija-Utgivare-Publisher

Kansanterveyslaitos (KTL)

Mannerheimintie 166

00300 Helsinki

Puh. vaihde (09) 474 41, telefax (09) 47448408

Folkhälsoinstitutet

Mannerheimvägen 166

00300 Helsingfors

Tel. växel (09) 474 41, telefax (09) 47448408

National Public Health Institute

Mannerheimintie 166

FIN-00300 Helsinki, Finland

Telephone +3589474 41, telefax +358947448408

ISBN 978-951-740-803-5

ISSN 0359-3584

ISBN 978-951-740-804-2 (pdf)

ISSN 1458-6290 (pdf)

Kannen kuva - cover photo: Timo Löfgren

Yliopistopaino

Helsinki 2008 


\section{S upervised by}

Docent Outi Lyytikäinen MD, PhD Department for Infectious Disease Epidemiology and Control National Public Health Institute (KTL) Helsinki, Finland

$$
\text { and }
$$

Docent Harri Saxén, MD, PhD Hospital for Children and Adolecents Helsinki University Central Hospital Helsinki, Finland

Revi e we d by

Docent Liisa Lehtonen, MD, PhD Department of Pediatrics Turku University Hospital Turku, Finland

$$
\text { and }
$$

Docent Risto Vuento, MD, PhD

Centre for Laboratory Medicine

Tampere University Hospital

Tampere, Finland

\section{Op p o n e n t}

Docent Marjo Renko, MD, PhD

Department of Pediatrics

Oulu University Hospital

Oulu, Finland 

To Janne, Henrik, Axel, and Elsa

"Good surveillance does not necessarily ensure the making of the right decisions, but it reduces the chances of wrong ones."

Dr. Alexander Langmuir, 1963 
Emmi Sarvikivi, Healthcare-associated infections in pediatrics

Publications of the National Public Health Institute, A11/2008, 93 Pages

ISBN 978-951-740-803-5; 978-951-740-804-2 (pdf-version)

ISSN 0359-3584; 1458-6290 (pdf-version)

http://www.ktl.fi/portal/4043

\section{ABSTRACT}

Background and aims. Healthcare-associated infections (HAIs) are known to increase the risk for patient morbidity and mortality in different healthcare settings and thereby to cause additional costs. HAIs typically affect patients with severe underlying conditions, such as patients treated in intensive care units, or patients who have undergone medical procedures, e.g., surgery. HAIs are prevalent also among pediatric patients, but the distribution of the types of infection and the causative agents differ from those detected in adults. The aim of this study was to obtain information on pediatric HAIs in Finland through an assessment of the surveillance of bloodstream infections (BSIs), through two outbreak investigations in a neonatal intensive care unit (NICU), and through a study of postoperative HAIs after open-heart surgery.

Methods. The Hospital for Children and Adolescents of the Helsinki University Central Hospital has participated in the BSI surveillance of the Finnish Hospital Infection Program since 1999. These data were utilized in all studies. The epidemiological features of pediatric BSIs were assessed. For the outbreak investigations, case definitions were set and data collected from microbiological and clinical records. The antimicrobial susceptibilities of the Serratia marcescens and the Candida parapsilosis isolates were determined. The $S$. marcescens isolates were genotyped with pulsed-field gel electrophoresis and the $C$. parapsilosis blood culture isolates (obtained between the years 1990 and 2002) with Southern blot hybridization by use of a DNA fingerprinting probe. Patient charts were reviewed for the case-control and cohort studies during the outbreak investigations, as well as for those patients who acquired surgical site infections (SSIs) after having undergone open-heart surgery. Also a prospective postdischarge study was conducted to detect postoperative HAIs after open-heart surgery.

Results. During 1999-2006, the overall annual BSI rate was 1.6/1,000 patient-days (range by year, 1.2-2.1). High rates (average, 4.9 and $3.2 \mathrm{BSIs} / 1,000$ patient-days) were detected in hematology and neonatology units. Coagulase-negative staphylococci were the most common pathogens both hospital-wide and in each patient group. The overall mortality was 5\%. The genotyping of the $15 \mathrm{~S}$. marcescens isolates revealed three independent clusters. All of the $26 \mathrm{C}$. 
parapsilosis isolates studied proved to be indistinguishable. No common source was identified for either of the outbreaks, but the NICU was overcrowded during the $S$. marcescens clusters. In both investigations, low birth weight and prematurity were identified as risk factors. A negative correlation between C. parapsilosis BSIs and fluconazole use in the NICU was detected, and the isolates derived from a single initially susceptible strain became less susceptible to fluconazole over time. Eighty postoperative HAIs, including all severe infections, were detected during hospitalization after open-heart surgery; $34 \%$ of those HAIs were SSIs and $25 \%$ were BSIs. The postdischarge study found 65 infections likely to be associated with hospitalization. The majority $(89 \%)$ of them were viral respiratory or gastrointestinal infections, and these often led to rehospitalizations. Of the SSIs, 20\% were detected after discharge.

Conclusions. The annual hospital-wide BSI rates were stable, and the significant variation detected in some units could not be seen in overall rates. Further studies with data adequately adjusted for risk factors are needed to assess BSI rates in the patient groups with the highest rates (hematology, neonatology). The outbreak investigations showed that horizontal transmission was common in the NICU. Overcrowding and lapses in hand hygiene probably contributed to the spreading of the pathogens. Following long-term use of fluconazole in the NICU, resistance to fluconazole developed in $C$. parapsilosis. Almost one-fourth of the patients who underwent open-heart surgery acquired at least one HAI. All severe HAIs were detected during hospitalization. The postdischarge study found numerous viral infections, which often led to rehospitalization. Only superficial SSIs, which did not affect the patient outcome, were detected after discharge, suggesting that routine postdischarge surveillance may not be necessary in this patient group.

Keywords: bacteremia, cross infection, epidemiologic studies, fungemia, infection control, molecular epidemiology, neonatal intensive care, pediatric hospitals, surgical site infection 
Emmi Sarvikivi, Healthcare-associated infections in pediatrics

Kansanterveyslaitoksen julkaisuja, A11/2008, 93 sivua

ISBN 978-951-740-803-5; 978-951-740-804-2 (pdf-versio)

ISSN 0359-3584; 1458-6290 (pdf-versio)

http://www.ktl.fi/portal/4043

\section{TIIVISTELMÄ}

Hoitoon liittyvät infektiot eli sairaalainfektiot lisäävät potilaiden sairastavuutta ja kuolleisuutta terveydenhuollon eri laitoksissa. Sairaalainfektioita esiintyy erityisesti kirurgisia toimenpiteitä tai tehohoitoa tarvitsevilla potilailla sekä potilailla, joiden vastustuskyky on perussairauksien vuoksi heikentynyt. Lasten sairaalainfektioiden aiheuttajat ja infektiotyypit poikkeavat aikuisten infektioista. Tämän tutkimuksen tavoitteena oli selvittää sairaalainfektioiden esiintyvyyttä suomalaisessa lastensairaalassa eri potilasryhmien ja infektiotyyppien osalta. Väitöskirja koostuu neljästä osatyöstä: veriviljelypositiivisten infektioiden seurantatutkimuksesta, kahdesta vastasyntyneiden teho-osastolla tehdystä epidemiaselvityksestä sekä sydänleikattujen lasten leikkauksenjälkeisiä sairaalainfektioita käsittelevästä tutkimuksesta.

Tutkimusaineisto kerättiin Helsingin yliopistollisen keskussairaalan Lasten ja nuorten sairaalassa (LNS) vuosina 1999-2006. LNS on osallistunut valtakunnallisen sairaalainfektio-ohjelman veriviljelypositiivisten sairaalainfektioiden seurantaan vuodesta 1999 lähtien, ja tätä seuranta-aineistoa käytettiin kaikissa väitöskirjan osatöissä. LNS:ssa 1999-2006 todettujen veriviljelypositiivisten sairaalainfektioiden epidemiologisia piirteitä tarkasteltiin sekä koko sairaalassa että eri yksiköissä. Vastasyntyneiden teho-osastolla ilmenneitä Serratia marcescens ja Candida parapsilosis -epidemioita tutkittiin tapaus-verrokki- ja kohorttitutkimusasetelmien avulla, tiedot tutkimusta varten kerättiin tapausmääritelmän perusteella valittujen potilaiden laboratoriovastauksista ja sairauskertomuksista. $S$. marcescens ja $C$. parapsilosis -kantojen mikrobilääkeherkkyydet määritettiin ja kannat tyypitettiin DNA-pohjaisten menetelmien avulla. Avosydänleikkauksen läpikäyneiden lasten sairaalainfektioita selvitettiin sekä hoitojakson ajalta että kotiutuksen jälkeen. Hoitojakson aikana ilmenneet leikkausalueen infektiot varmistettiin tarkastelemalla sairauskertomuksia, ja kotiutuksen jälkeiset infektiot kartoitettiin kotiutusvaiheessa jaetun kyselylomakkeen avulla.

Kahdeksan vuoden seuranta-aikana veriviljelypositiivisten infektioiden esiintyvyys oli 1,6 infektiota 1000 hoitopäivää kohden (vaihteluväli vuosittain: 1,2-2,1). Esiintyvyys oli korkeampi hematologisia potilaita (4,9 infektiota/1000 hoitopäivää) ja sairaita vastasyntyneitä hoitavissa yksiköissä (3,2 infektiota/1000 hoitopäivää). 
Koagulaasinegatiiviset staflylokokit olivat yleisimpiä taudinaiheuttajia. Veriviljelypositiivisiin infektioihin liittyvä tapauskuolleisuus oli $5 \%$. Vastasyntyneiden tehoosastolla todettiin kantojen tyypityksen perusteella kolme itsenäistä $S$. marcescens bakteerin aiheuttamaa epidemiaa. Kaikki 26 tutkittua $C$. parapsilosis -kantaa olivat geneettisesti identtisiä, mutta herkkyysmääritykset osoittivat flukonatsoliresistenssin kehittymisen ajan kuluessa. Veriviljelypositiivisten $C$. parapsilosis -infektioiden esiintyminen ja flukonatsoliestolääkityksen käyttö korreloivat käänteisesti. Yhdellekään epidemialle ei löytynyt selvää lähdettä. Osasto oli kuitenkin epidemioiden aikana ajoittain ylikuormitettu. Avosydänleikatuilla potilailla todettiin 80 leikkauksen jälkeiseen hoitojaksoon liittyvää sairaalainfektiota: $34 \%$ näistä oli leikkausalueen infektioita ja $25 \%$ veriviljelypositiivisia infektioita. Kotiutuksen jälkeisessä kyselytutkimuksessa 65 potilaalla ilmeni kolmen vuorokauden kuluessa kotiutuksesta infektio-oireita, joista valtaosa (89\%) oli todennäköisesti virusten aiheuttamia hengitystie- tai suolistoinfektioita. Kaikki vakavat infektiot todettiin sairaalajakson aikana, mutta kotiutuksen jälkeen todetuista virusinfektioista viidesosa johti uuteen sairaalahoitojaksoon. Leikkausalueen infektioista $20 \%$ todettiin kotiutuksen jälkeisessä seurannassa.

Tutkimus osoitti, että veriviljelypositiivisten sairaalainfektioiden esiintyvyys pysyi LNS:ssa seurantajakson aikana vakaalla tasolla. Hematologisia potilaita ja sairaita vastasyntyneitä hoitavissa yksiköissä esiintyvyys oli huomattavasti keskimääräistä suurempi, ja näissä ryhmissä ilmeni myös suuria vuosittaisia vaihteluja infektioluvuissa. Näiden potilasryhmien yksityiskohtainen tarkastelu ei kuitenkaan ollut mahdollista, koska aineistoa ei voitu mukauttaa riskitekijöiden suhteen potilasjoukossa vuosittain esiintyvän vaihtelun hallitsemiseksi. Epidemiaselvitykset osoittivat, että potilaasta toiseen tapahtuva tartuntareitti oli tavallinen, ja että osaston ylikuormitus sekä siihen liittyvät ongelmat käsihygienian toteutumisessa todennäköisesti edesauttoivat epidemioiden leviämistä. Flukonatsolin pitkäaikainen käyttö osastolla johti flukonatsoliresistenttien $C$. parapsilosis -alatyyppien kehittymiseen. Avosydänleikatuista lapsista jopa joka neljäs sai sairaalainfektion leikkauksen jälkeen. Vakavat infektiot todettiin sairaalajakson aikana, mutta kotiutuksen jälkeen esiintyi runsaasti virusinfektioita, jotka aiheuttivat usein uuden sairaalahoitojakson. Vakavia leikkausalueen infektioita ei todettu kotiutuksen jälkeen, eikä rutiininomainen kotiutuksen jälkeinen seuranta siten välttämättä ole tarpeellista tämän toimenpideryhmän osalta.

Avainsanat: infektioepidemiologia, infektioiden torjunta, lastensairaala, leikkausalueen infektio, risti-infektio, sairaalainfektio, tyypitysmenetelmä, vastasyntyneiden tehohoito, veriviljelypositiivinen infektio 



\section{CONTENTS}

Abbreviations..........................................................................................................14

List of original publications..................................................................................15

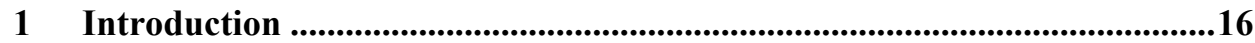

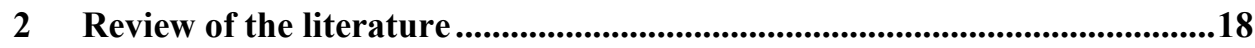

2.1 HEALTHCARE-ASSOCIATED INFECTIONS IN CHILDREN ….........18

2.1.1 General principles of healthcare-associated infections................... 18

2.1.2 Importance to public health ...................................................... 20

2.1.3 Patients at risk.......................................................................... 21

2.1.4 Bloodstream infections ......................................................... 22

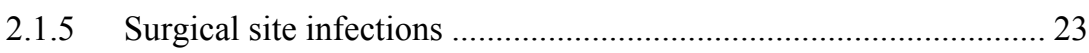

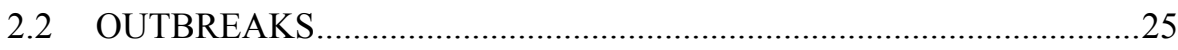

2.2.1 Definition and importance ........................................................ 25

2.2.2 Outbreaks in neonatal intensive care units ................................... 25

2.2.3 Hand hygiene and cross-transmission ........................................... 29

2.3 SURVEILLANCE OF PEDIATRIC HEALTHCARE-ASSOCIATED

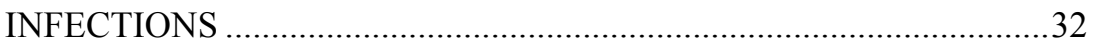

2.3.1 Purpose and objectives of surveillance ......................................... 32

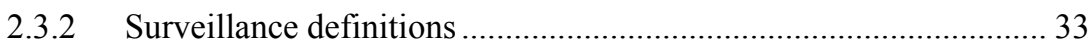

2.3.3 Case finding and ascertainment .................................................... 35

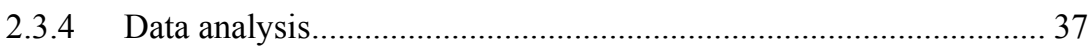

2.3.5 Surveillance feedback................................................................... 38

2.3.6 Public reporting of healthcare-associated infection rates ............... 39

3 Aims of the study .............................................................................................41

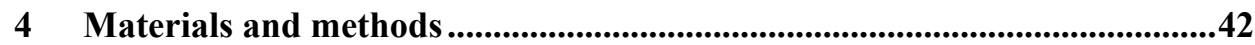

4.1 DESCRIPTION OF THE HOSPITAL AND THE NEONATAL INTENSIVE CARE UNIT ....................................................................42

4.2 SURVEILLANCE METHODOLOGY FOR BLOODSTREAM INFECTIONS OF THE FINNISH HOSPITAL INFECTION

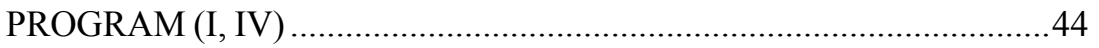

4.2.1 In-hospital surveillance of bloodstream infections ......................... 44

4.2.2 Data management in the national database.................................... 45 


\subsection{SURVEILLANCE OF HEALTHCARE-ASSOCIATED}

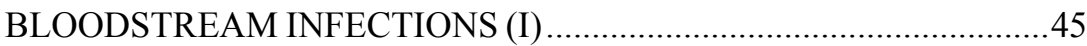

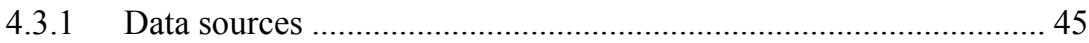

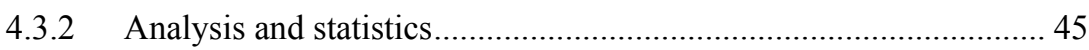

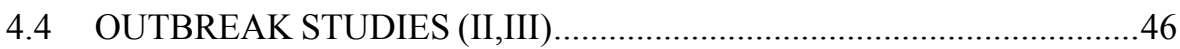

4.4.1 Outbreak descriptions and case definitions .................................... 46

4.4.2 Fluconazole prophylaxis and use (III) ......................................... 48

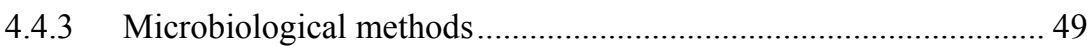

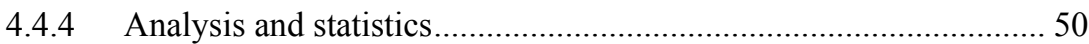

4.5 HEALTHCARE-ASSOCIATED INFECTIONS AFTER OPENHEART SURGERY IN CHILDREN (IV) …………...........................

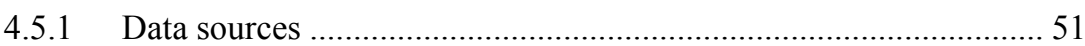

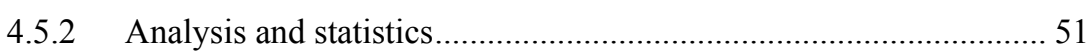

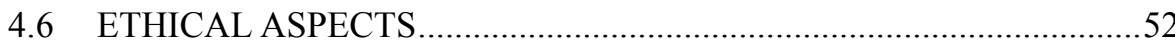

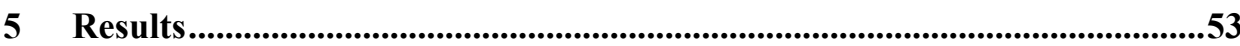

5.1 SURVEILLANCE OF HEALTHCARE-ASSOCIATED

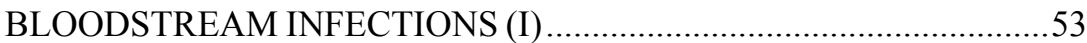

5.1.1 Characteristics of patients with bloodstream infections ................... 53

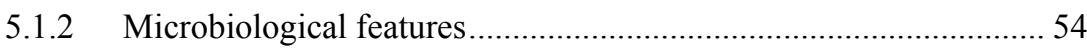

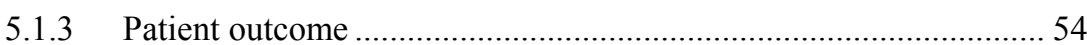

5.2 INVESTIGATION OF THE S. MARCESCENS OUTBREAK (II) ...........56

5.2.1 Description of the clusters and patient volume in the NICU ........... 56

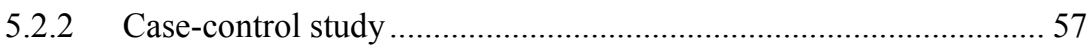

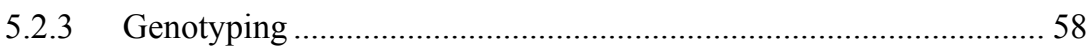

5.3 INVESTIGATION OF THE C. PARAPSILOSIS OUTBREAK (III) ........58

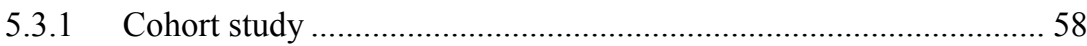

5.3.2 Fluconazole use and positive Candida cultures.............................. 60

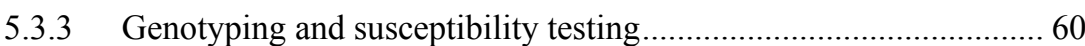

5.4 HEALTHCARE-ASSOCIATED INFECTIONS AFTER PEDIATRIC

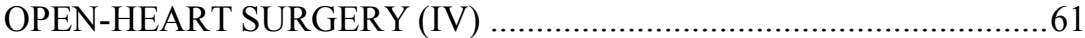

5.4.1 Characteristics of study patients and procedures .................................... 61

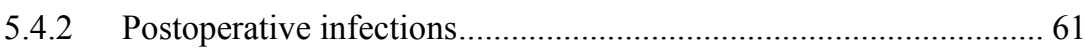

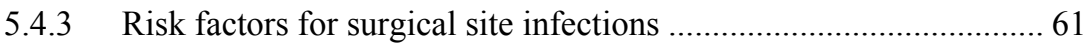




\subsection{SURVEILLANCE OF HEALTHCARE-ASSOCIATED}

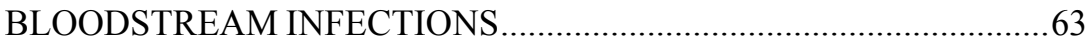

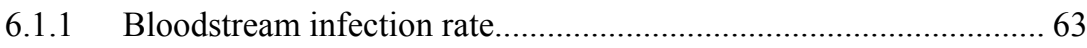

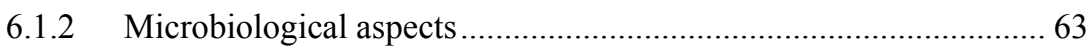

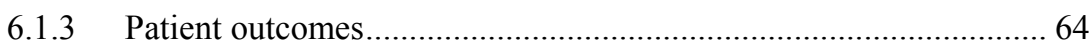

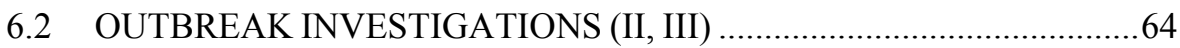

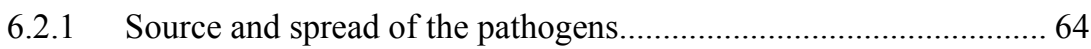

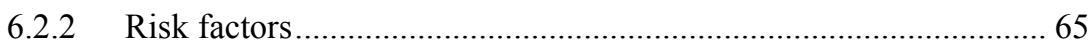

6.2.3 Role of hand hygiene, overcrowding and understaffing ................... 65

6.2.4 Emergence of fluconazole resistance in C. parapsilosis (III) ........... 66

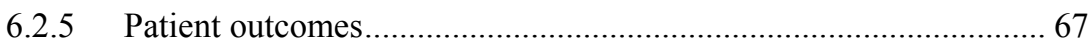

6.3 HEALTHCARE-ASSOCIATED INFECTIONS AFTER OPEN-

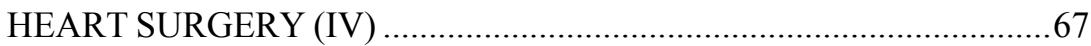

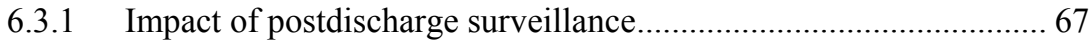

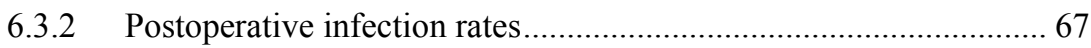

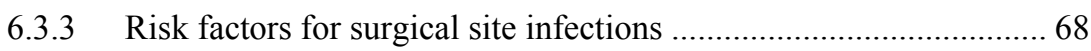

6.4 UNRESOLVED ISSUES AND FUTURE CONSIDERATIONS .............68

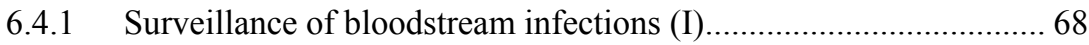

6.4.2 Limitations regarding data collection (II-IV) ........................................... 69

6.4.3 Compliance with infection control guidelines (I-IV) ...................... 70

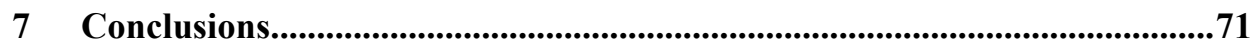

8 Acknowledgments ...........................................................................................72

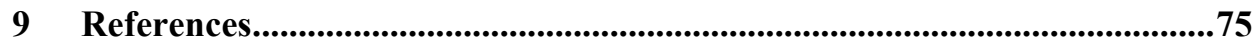




\section{ABBREVIATIONS}

AFLP

ALFA

AP-PCR

ASA

BSI

CDC

CI

CoNS

ERIC

GNB

HAI

HCW

HELICS

ICU

KISS

MIC

NHSN

NICU

NNIS

OR

RAPD

REA

RFLP

RR

PCR

PFGE

PICU

SIRO

SENIC

$\mathrm{S}_{\mathrm{AB}}$

SSI

UTI

VAP

VLBW
Amplified fragment-length polymorphism

Automated laser fluorescence analysis

Arbitrarily primed polymerase chain reaction

American Society of Anesthesiologists

Bloodstream infection

Centers for Disease Control and Prevention (US)

Confidence interval

Coagulase-negative staphylococci

Enterobacterial repetitive intergenic consensus

Gram-negative bacteria

Healthcare-associated infection

Healthcare worker

The Hospitals in Europe Link for Infection Control through

Surveillance

Intensive care unit

Krankenhaus Infektions Surveillance System (Germany)

Minimal inhibitory concentration

National Healthcare Safety Network (US)

Neonatal intensive care unit

National Nosocomial Infection Surveillance System (US)

Odds ratio

Random amplified polymorphic DNA

Restriction-endonuclease analysis

Restriction fragment length polymorphism

Relative risk

Polymerase chain reaction

Pulsed-field gel electrophoresis

Pediatric intensive care unit

Finnish Hospital Infection Program

Study on the Efficacy of Nosocomial Infection Control

Similarity coefficient

Surgical site infection

Urinary tract infection

Ventilator-associated pneumonia

Very low birth weight, $\leq 1500 \mathrm{~g}$ 


\section{LIST OF ORIGINAL PUBLICATIONS}

This thesis is based on the following original articles referred to in the text by their Roman numerals:

I Sarvikivi E, Lyytikäinen O, Vaara M, Saxén H. Nosocomial bloodstream infections in children: an eight-year experience at a tertiary care hospital in Finland. Submitted.

II Sarvikivi E, Lyytikäinen O, Salmenlinna S, Vuopio-Varkila J, Luukkainen P, Tarkka E, Saxén H. Clustering of Serratia marcescens infections in a neonatal intensive care unit. Infect Control Hosp Epidemiol. 2004;25(9):723-9.

III Sarvikivi E, Lyytikäinen O, Soll DR, Pujol C, Pfaller MA, KoukilaKähkölä P, Richardson M, Luukkainen P, Saxén H. Emergence of fluconazole resistance in a Candida parapsilosis strain that caused infecions in a neonatal intensive care unit. J Clin Microbiol. 2005;43(6):2729-35.

IV Sarvikivi E, Lyytikäinen O, Nieminen H, Sairanen H, Saxén H. Nosocomial infections after pediatric open-heart surgery. Am J Infect Control 2008. In press.

These articles are reproduced with the kind permission of their copyright holders. 


\section{INTRODUCTION}

Healthcare-associated infections (HAIs) are the most common complications affecting hospitalized patients [1]. In the United States, the HAI rate has been reported to range from 4.5 to 5.5 per 100 admissions during 1975-2002 [2, 3]. HAI rates vary widely between different patient populations, with the highest rates usually occurring in intensive care units (ICUs) [3]. This also applies to pediatric patients: patients treated in neonatal intensive care units (NICUs) or pediatric intensive care units (PICUs) are at the highest risk for HAIs [4]. Bloodstream infections (BSIs) are the most common HAIs in these settings [5-8], often leading to increased morbidity and mortality [9-11] as well as long-term consequences [12], and also resulting in pain and suffering of the child and the family. Furthermore, prolonged need of hospitalization due to HAIs may give rise to substantial additional costs [13-16].

Surgical site infections account for up to $40 \%$ of HAIs in surgical patients [17]. In adults undergoing coronary artery bypass surgery, SSIs reportedly occur after $8 \%$ $10 \%$ of procedures $[18,19]$, and a considerable proportion of these infections was reportedly detected after discharge. Pediatric studies on open-heart surgery patients to date have reported lower SSI rates [20-23], suggesting that other types of HAI predominate in these patients [22-24]. However, none of these studies had conducted postdischarge surveillance, which may have affected the SSI rates.

Only a small proportion of HAIs occur as epidemics, but often the consequences could be devastating for the affected patients $[25,26]$. Systematic analysis of such events can help in controlling them and may lead to a re-evaluation of prevailing infection control practices [27].

Surveillance of HAIs has proved essential in infection control; by determining the baseline HAI rates, changes in the rates can be detected and further measures introduced [28]. Recent reports suggest that the effect of surveillance in reducing HAI rates is significant, and that at least $20 \%$ of the HAIs could be preventable [29, $30]$. For some HAI types, the proportion of potentially preventable infections may be even larger, up to $95 \%$ [31]. National HAI surveillance systems have been established in the US since the 1970s and in Europe since the 1990s [32]. The Finnish Hospital Infection Program (SIRO) began in 1997; the national database includes systematically collected information on healthcare-associated BSIs and SSIs as reported by the participating hospitals since 1999.

The purpose of this study was to assess the epidemiology of pediatric HAIs in the largest pediatric hospital in Finland, which, along with the other four tertiary care 
centers, is responsible for the care of the most severely ill patients. Some functions, such as open-heart surgery and organ transplants, are nationally centered in this hospital serving a population of 5.3 million. SIRO surveillance data on BSIs were available for over eight years, thus permitting evaluation of the impact of the surveillance. The epidemics confronted in the NICU of the hospital were investigated. A prospective postdischarge study was conducted on the infections after open-heart surgery, and the total burden of postoperative HAIs in this patient population was investigated. 


\section{REVIEW OF THE LITERATURE}

\subsection{HEALTHCARE-ASSOCIATED INFECTIONS IN CHILDREN}

\subsubsection{General principles of healthcare-associated infections}

Definition of a healthcare-associated infection

A HAI, or nosocomial infection, is defined as a localized or systemic pathological reaction that results from the presence of a microorganism or its toxin and that was not incubating or present at the time of admission to the hospital [33, 34]. An infection that is acquired in the hospital but becomes evident only after discharge, is also considered nosocomial. The incubation period varies with the type of pathogen, and each infection must be assessed individually for evidence that links it to hospitalization or healthcare-associated intervention. Most bacterial HAIs become evident 48 hours or more after admission, and consequently, a time limit of 48 hours has been applied as a rule of thumb [35].

Infection vs. colonization

Infection implies the replication of organisms in the tissues of a host; the related clinical manifestation is known as a disease. Colonization is defined as the presence of microorganisms in or on the host without causing clinical expression or a detected immune response. Colonization can be differentiated from subclinical infection by defining an immune response, such as a serologic reaction. If such information is not available, it is customary to use the term colonization [33].

Sources and modes of transmission

HAIs can be caused by endogenous or exogenous organisms. Endogenous infections usually occur as a result of healthcare-associated interventions (e.g., surgical procedures or the insertion of vascular catheters or other indwelling devices) [34], by colonization and subsequent infection with microorganisms from the hospital environment due to immunosuppression, or by normal flora altered through antimicrobial therapy [36]. Exogenous infections result from the transmission of organisms from the hospital environment [34].

The transmission of exogenous organisms is also called horizontal or crosstransmission. The source of the microorganism may be human (e.g., an infected patient, the index case) or environmental (e.g., contaminated devices or infusates). 
Colonized patients or healthcare workers (HCWs) may serve as reservoirs or secondary sources [37]. Transmission may occur through direct contact, a common source, air or vectors, or sometimes through a combination of these routes $[38,39]$ (Figure 1). Person-to-person transmission is the most common means of transmission and may occur either through direct physical contact with an infected or colonized person or through indirect contact, such as the transfer from one patient to another on the hands of HCWs [40].

\section{Figure 1.}

Some possible transmission routes of Staphylococcus epidermidis [39], a common pathogen causing healthcare-associated infections. $a=$ direct contact transmission, $b=$ indirect contact transmission, $c=$ direct airborne transmission, $d=$ indirect airborne transmission. (Reproduced with permission of Dr. Göran Hedin.)

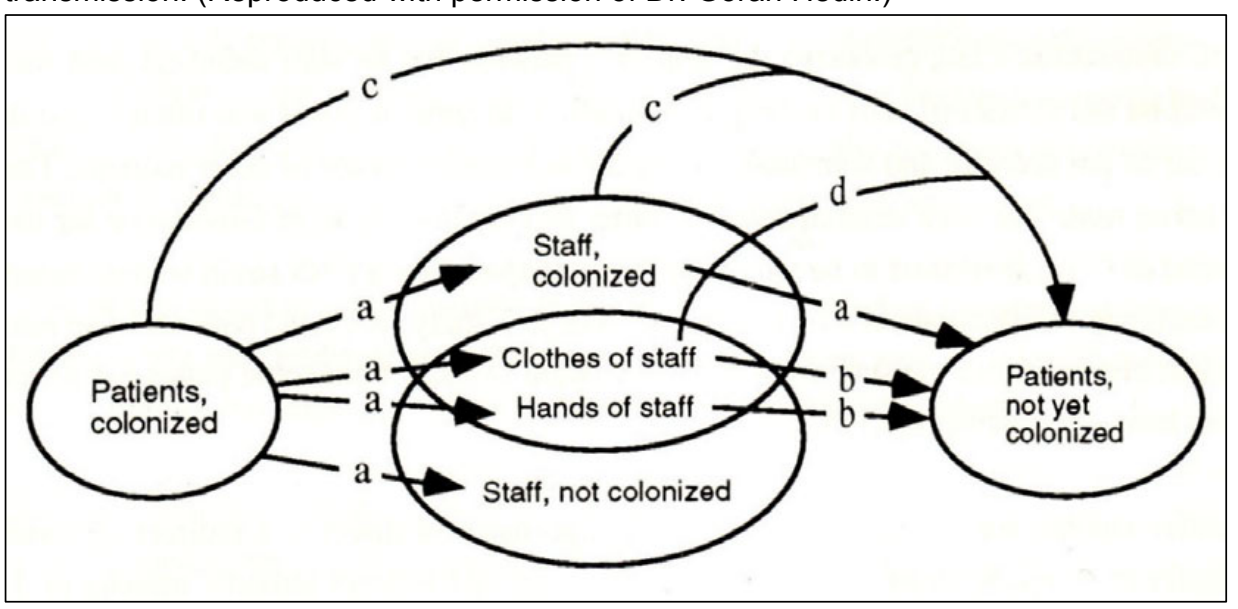

Caus ative a gents

The causative microorganisms vary depending on the type of HAI. Among the most common nosocomial pathogens are Eschericia coli, typical of urinary tract infections (UTIs), as well as Staphylococcus aureus and coagulase-negative staphylococci (CoNS), which are commonly isolated from many body sites [41]. The first national prevalence survey in Finland, conducted in 2005, identified E. coli, $S$. aureus and Enterococcus faecalis as the three most common pathogens causing HAIs in adult patients [42]. In pediatric studies, CoNS (20\%-26\%), Pseudomonas aeruginosa (5\%-20\%), S. aureus (11-15\%), and Candida species (4\%-9\%) were predominant pathogens, in addition to viruses (mostly rotavirus and respiratory syncytial virus), which were identified in $22 \%-23 \%$ of all HAIs [43, 44]. 


\subsubsection{Importance to public health}

M o r b i d ity

National prevalence studies in different European countries have revealed hospitalwide HAI rates ranging from $3.5 \%$ to $9.3 \%$ [45]. The Finnish prevalence study found that $8.5 \%$ of patients had at least one HAI on the day of the survey [42]. In the United States, the estimated number of HAIs was 1.7 million in 2002, representing a rate of 9.3 HAIs per 1,000 patient-days or 4.5 per 100 admissions [3]. Pediatric HAIs are known to differ in many ways from those detected in adult patients. In general, the HAI rates reported in pediatric patients have usually been lower than those in adults [38]. When viral infections are included, however, HAI rates in children are substantially higher than those in adults (up to 7 vs. 4 infections per 100 patients) [43]. Children tend to have fewer SSIs, UTIs, and ventilator-associated pneumonias (VAPs) than do adults, but more BSIs, viral gastrointestinal and respiratory infections, and cutaneous infections [46]. Viral HAIs tend to occur in epidemics, and their occurrence is greatly dependent on the seasonal variation of community-acquired diseases [47, 48]. Strict infection control measures, including the early identification and isolation of potential carriers, are required to prevent the spread of viral pathogens [49].

A large Canadian study reported an overall HAI rate of 6.0 infections per 100 admissions [43]. The HAI rate varied depending on the ward or pediatric specialty; more than half of the infections were detected in just 6 of the 21 wards; the highest HAI rate was detected in the NICU. When the HAI rate was sorted by the age of the patients, the HAI rate in patients under two years of age (11.5 infections per 100 admissions) was substantially higher than in the other age groups (3.6 infections per 100 admissions in patients aged 2 to 4 years; 2.6 infections per 100 admissions in patients 5 years of age or older). A European study of 17 pediatric centers reported an overall HAI rate of $2.5 \%$ including five types of HAI: BSIs, lower respiratory tract infections, UTIs, SSIs, and gastrointestinal infections [44].

M o r t a 1 it y

HAIs have been estimated to cause attributable mortality of $7 \%-9 \%$ in adults [50, 51]. In the US, $6 \%$ of patients with at least one HAI in 2002 were reported to have had a cause of death associated with that HAI [3]. Few reports exist that describe mortality associated with HAIs in pediatric patients. A Brazilian study attributed a case-fatality of $2 \%$ with HAIs in general [52]. The majority of the severe HAIs (e.g., BSIs) associated with increased mortality occur, however, in patients with severe underlying conditions. Reported mortality rates associated with BSIs have been 
substantially higher: $9 \%-14 \%$ in pediatric patients in general $[53,54], 18 \%-20 \%$ in PICUs [55, 56], and $8 \%-18 \%$ in NICUs $[10,57]$.

Cos $\mathrm{t}$

Prolongation of the hospital stay or intensive care, as well as an increased need for diagnostic examinations (e.g., radiology, laboratory) and antimicrobial medication, are the main sources of the significant additional costs associated with HAIs. HAIs have been estimated to prolong an average hospital stay by 3 to 23 days [50, 51, 58, 59]. The average additional cost associated with a HAI was as high as USD 5,300 [51]. A study conducted in a PICU found the direct cost of PICU admission attributable to nosocomial primary BSI to be USD 39,219 [15]. A Belgian study conducted in an NICU over a 24-month period found HAIs to lengthen the average hospital stay with an average of 24 days, and the mean additional cost of a HAI to be EUR 11,750 [13]. These cost-effectiveness studies have been criticized for using low quality data for some parameters and a lack of transparency, as well as for using short time-horizons and narrow economic perspectives [60]. Thus, the figures presented above probably overestimate the costs, but prevention of these infections is nevertheless likely to save not only lives, but also a significant amount of money.

\subsubsection{Patients at risk}

Children with immunological defects are at greater risk for acquiring HAIs. Neonates are a typical patient group at risk; several components of the immune system exhibit diminished functional capacity enhancing thus susceptibility to infections and may also affect the duration of microorganism shedding [61]. The basis of increased susceptibility is not fully understood, but at least the lack of preexisting immunological memory (adaptive immunity) as well as impaired innate immune mechanisms (e.g., decreased responses to pathogen-derived stimuli or decreased ability for sustained induction of inflammatory cytokine production) have been proposed to play a role $[62,63]$. Due to the naïve adaptive immune system, a newborn infant depends on passively acquired maternal antibodies, and because the transmission of these antibodies to the fetus begins at approximately week 24-26 of gestation (reaching the adult levels only near full term) prematurely born neonates typically possess lower antibody levels than full term infants [64]. On the other hand, these passively acquired antibodies may provide inadequate protection against the hospital endemic microorganisms to which the infant will be exposed in the NICU. While healthy newborns are likely to acquire from the mother the majority of the microbial flora colonizing the mucosal surfaces and the skin, neonates hospitalized in an NICU setting are likely to acquire their endogenous microbial flora from endemic microorganisms present in the NICU and modified by frequent 
exposure to antimicrobial agents $[65,66]$. Moreover, NICU patients are critically ill, and therefore often require the use of invasive procedures, such as mechanical ventilation or parenteral nutrition and prolonged hospitalization, all of which are likely to increase the risk for acquiring a nosocomial pathogen $[13,40]$.

Patients with immunosuppressive treatments are also at an increased risk for contracting HAIs [38, 43]. In the Finnish patient population, children with hematological or other malignancies and organ transplant recipients are the most important subgroups receiving these treatments [67]. A major problem is treatmentinduced neutropenia, which exposes patients to life-threatening infections. As the intensity of modern cancer chemotherapy has increased, fungal infections have also become more frequent [68]. BSIs, the most prevalent HAIs in pediatric hematology/oncology patients, seem to be associated with the use of a central venous catheter (CVC) in most cases [69, 70].

Children with congenital anomalies could have immunological deficiencies due to specific syndromes (e.g., Wiscott-Aldrich, DiGeorge) or loss of protective barriers (e.g., cleft palate, meningomyelocele) [46]. Such children often require multiple hospitalizations, their hospital stays are likely to be extended, and they usually need surgical procedures and indwelling devices, all of which further increase the risk for HAIs.

\subsubsection{Bloodstream infections}

BSIs are the most common severe HAIs in children [71-73]. Advances in neonatal intensive care have led to the improved survival of prematurely born infants, but HAIs, especially BSIs, frequently complicate the hospitalization of these infants [5, 10, 11, 64, 74-76]. Neonatal BSIs are categorized as early-onset infections, occurring shortly after birth as a result of perinatal infection, and as late-onset infections, usually occurring after the first week of life. Most early-onset infections become evident within the first 48-72 hours of life. Consequently, a time limit of three days is often used in definitions. Early and late-onset BSIs differ in risk factors and the distribution of causing pathogens; early-onset infections typically result from maternal microorganisms, most commonly Streptococcus agalactiae and E. coli, and are associated with obstetric complications such as chorionamnionitis, maternal fever, or prolonged rupture of membranes [40, 77, 78]. Late-onset BSIs are more likely to be acquired from the hospital environment. Coagulase-negative staphylococci (CoNS), Candida species, and Gram-negative bacteria (e.g., E. coli, Klebsiella, Pseudomonas, Enterobacter, and Serratia species) are typical pathogens; prematurity, low birth weight, central venous catheters, mechanical ventilation, 
parenteral nutrition and a long hospital stay have been reported as risk factors for late-onset BSIs [10, 11, 79-81].

Late-onset BSIs are an important problem in very low birth weight (VLBW, $\leq 1500$ g) neonates. In a large VLBW infant population in the US, $21 \%$ of the patients had $\geq 1$ episodes of blood culture-positive late-onset BSI, and as many as $46 \%$ of the infants with the lowest gestational ages $(<25$ weeks) acquired at least one BSI episode [10]. Furthermore, infants with birth weights $\leq 750 \mathrm{~g}$ were more likely to have multiple episodes of BSIs. Prolongation of need for intravenous access (central lines) and parenteral hyperalimentation as well as mechanical ventilation were strongly associated with increased risk for BSI in this study. Also dexamethasone treatment has been reported to increase the risk for BSIs [82].

In particular, the smallest VLBW infants seem to be at risk for candidal BSIs [83], which have also been associated with both dexamethasone therapy and prolonged treatment with antimicrobial agents $[84,85]$. The attack rate of invasive Candida infections over the past two decades has ranged from $3 \%$ to $17 \%$ among VLBW infants, and from $6 \%$ to $20 \%$ among extremely low birth weight infants $(\leq 1,000 \mathrm{~g})$, with a case-fatality of around $30 \%[10,86-95]$. The main causative agents causing candidemias in the VLBW infant population have been Candida albicans and Candida parapsilosis, and a shift towards the latter has occurred gradually [86, 96, 97]. The characterization of $C$. parapsilosis outbreak strains has revealed variation between $C$. parapsilosis strains in phenotypic markers, such as biofilm production; such factors may also play a role in the strain's ability to cause infection [98].

Candida species may colonize up to $60 \%$ of VLBW infants during the first weeks of their NICU stay [99]. Colonization at multiple sites and CVC colonization have been reported as independent risk factors for candidal BSI [100]. The use of fluconazole prophylaxis seems to be effective against fungal colonization as well as to prevent candidal BSI [91-95, 101-103]. None of the prophylaxis studies has reported changes in the fluconazole susceptibility of the Candida strains. However, fluconazole prophylaxis has been associated with increased risk for colonization with fungal isolates that are intrinsically resistant to fluconazole [104].

\subsubsection{Surgical site infections}

Surgical site infections are among the most common HAIs in adult patients $[17,42$, 105]. The proportion of SSIs of all HAIs in prevalence studies across Europe has varied between $14 \%$ and $48 \%$, whereas overall HAI rates were $4 \%-10 \%$ [45]. Pediatric prevalence studies have reported HAI rates of $7 \%-12 \%$, of which SSIs 
constituted $1 \%-17 \%[72,73,106,107]$. The overall SSI rates among children were approximately ten times lower than among adults in NNIS hospitals [108].

Cardiac surgery due to congenital heart disease refers to a heterogeneous group of procedures, most of which are unique to pediatric patients. Many of these operations must be performed within the first days of life, because of the severity of the condition, and many of these patients require multiple operations [109]. Pediatric studies have reported SSI rates between $2 \%$ and $8 \%$ after cardiac surgery (Table 1). The risk factors for SSI in these studies included young (neonatal) age, cyanotic heart disease, a high ASA score, an extended preoperative hospital stay, prolonged duration of surgery, an open chest postoperatively, and extended mechanical ventilation [20-24]. However, the widely used NNIS risk index score, which stratifies patients according to three risk factors (an ASA score $\geq 3$, a wound contamination classification of either contaminated or dirty, and a duration of operation longer than the $75^{\text {th }}$ percentile of the duration for each operative procedure) $[110,111]$ did not seem to adequately stratify pediatric cardiac surgery patients $[112,113]$. Similar results have been reported previously in adult patients with cardiothoracic operations [114].

\section{Table 1.}

Summary of studies reporting rates of healthcare-associated infections (HAls) after pediatric open-heart surgery. SSI = surgical site infection, BSI = bloodstream infection.

\begin{tabular}{|c|c|c|c|c|c|}
\hline \multicolumn{2}{|c|}{$\begin{array}{l}\text { No. of patients } \\
\text { (procedures) }\end{array}$} & \multirow{2}{*}{$\begin{array}{l}\% \text { of patients } \\
\text { with SSIs } \\
5.0^{\text {a) }}\end{array}$} & $\begin{array}{l}\% \text { of patients with } \\
\text { BSIs (primary BSIs) }\end{array}$ & $\begin{array}{l}\% \text { of patients } \\
\text { (procedures) } \\
\text { with HAls }\end{array}$ & \multirow{2}{*}{$\begin{array}{l}\text { Reference } \\
{[22]}\end{array}$} \\
\hline 242 & (256) & & $(5.0)$ & $20.2^{\text {a) }} \quad(19.1)$ & \\
\hline 104 & b) & 4.8 & $15.4^{\mathrm{c})}$ & 48.1 & [23] \\
\hline 335 & b) & 7.8 & 9.9 & 16.4 & [24] \\
\hline 1117 & (1117) & 3.4 & d) & d) & [21] \\
\hline 826 & $(826)$ & 2.3 & d) & d) & [20] \\
\hline 1580 & (1580) & 3.0 & d) & d) & [115] \\
\hline
\end{tabular}

a) Sternal wound infections only. Bacterial infections only.

b) The number of procedures not mentioned.

c) 6 episodes of clinical sepsis included.

d) Only SSIs reported. 


\subsection{OUTBREAKS}

\subsubsection{Definition and importance}

Epidemic HAIs, or outbreaks, are defined as hospital-acquired infections that represent an increase in incidence over expected rates. Nosocomial outbreaks occur relatively infrequently; they have been estimated to account for approximately $5 \%$ of all HAIs [116]. Yet, in settings such as ICUs, epidemics may account for a substantially higher percentage of HAIs [117]. Often these infections occur in small clusters, and even one episode of an uncommon infection may indicate an outbreak. On the other hand, if pathogens or anatomic sites of infections are not uncommon, a deviation from the baseline infection rate in a specific hospital unit can refer to epidemic transmission [116].

The rationale for investigating a recognized outbreak is to identify and eliminate the source of infection; the implementation of appropriate control measures to prevent further illness and death is essential. The outbreak may have ceased by the time of the investigation, but the decision to investigate the outbreak may still be justifiable. Strategies for preventing similar future outbreaks can be achieved and more about the diseases can be learned through outbreak investigations. Sometimes new diseases occur as outbreaks, and the investigation offers the opportunity to describe them. Other goals of the investigation may include evaluating existing prevention strategies or addressing public concerns about the outbreak [118].

An overview of published outbreak reports is required when the organism causing a suspected hospital outbreak has been identified. Gastmeier et al. have developed a systematic register of nosocomial outbreaks to assist with quick overviews [119]. The database covers approximately three fourths of all published outbreaks [120] and is regularly updated and freely accessible (http://www.outbreak-database.com). The database also provides structured information on the outbreaks, offering opportunities to search for various combinations of parameters, such as type of microorganism, setting, mode of transmission, type of infection, and risk factors.

\subsubsection{Outbreaks in neonatal intensive care units}

At the time of the search on 3 December 2007, the outbreak database contained information on 2,112 outbreaks, of which 460 were from neonatal departments. Thirty of these were $S$. marcescens outbreaks. Table 2 shows a summary of those outbreaks that were reported between the years 1990 and 2006 and that had occurred in NICUs. Most of the studies had utilized molecular typing methods to study the 


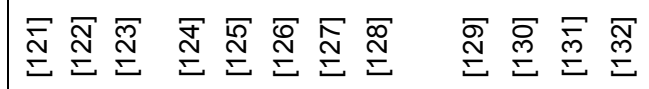

$\div .0$<smiles>COCCOCCO</smiles>

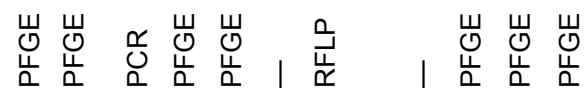

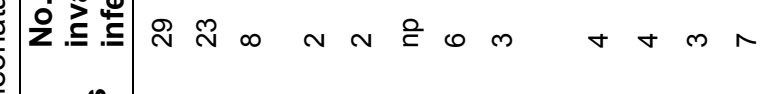

a 2 a $m$ n 40

之่

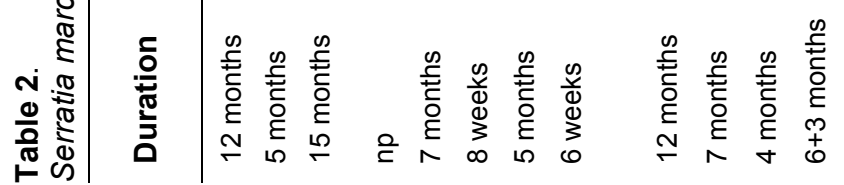




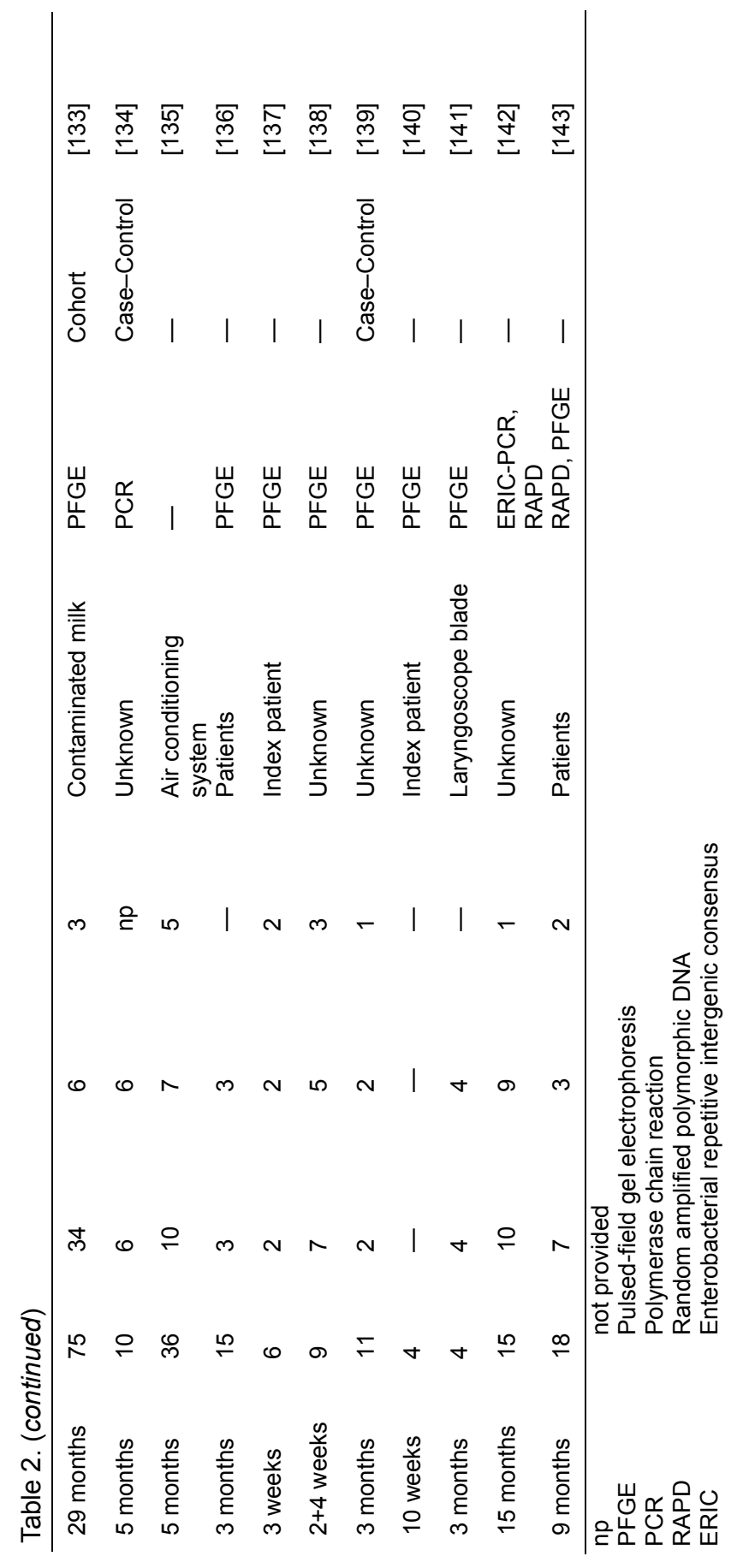




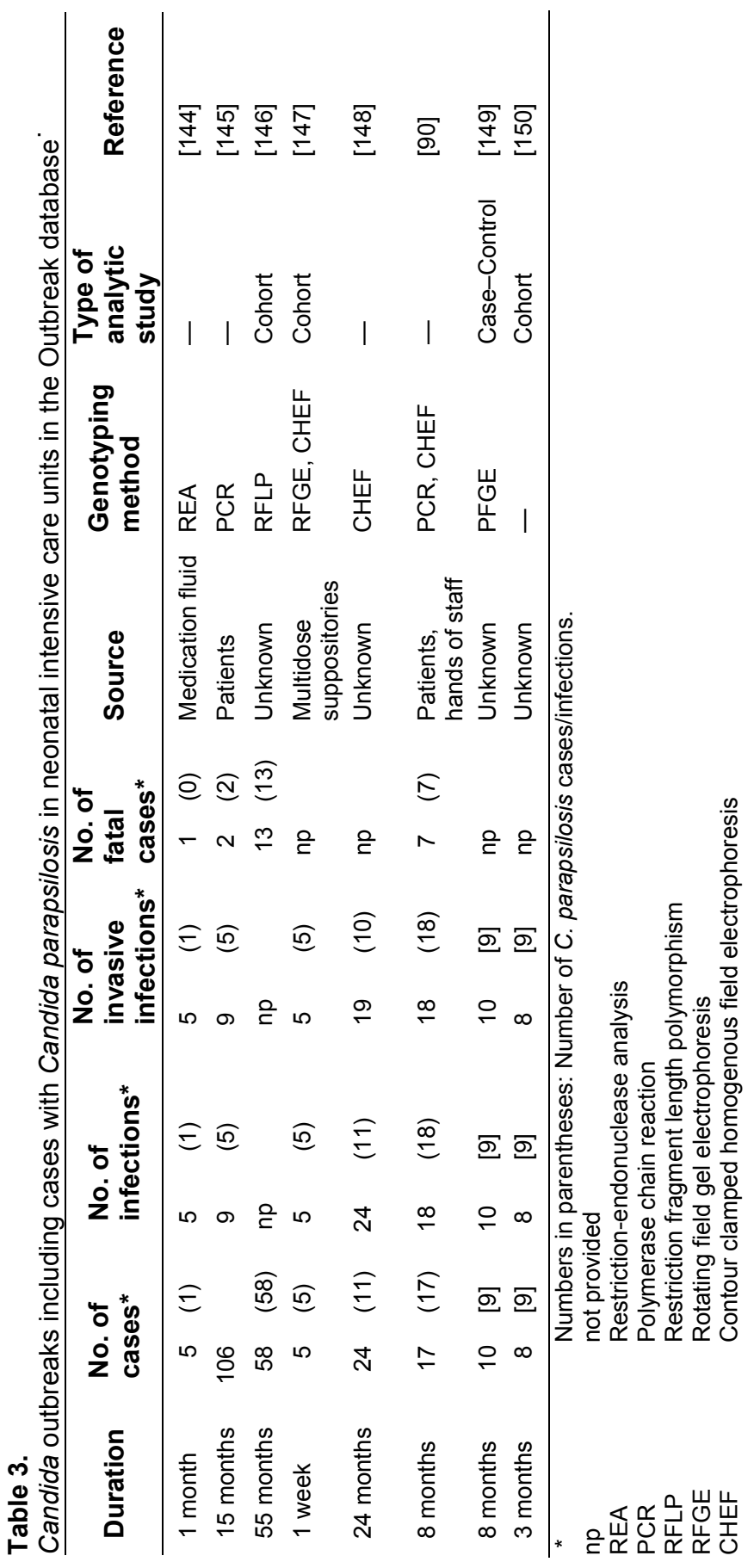


genetic relatedness of the isolates. However, few studies identified an environmental source for the outbreak, even if environmental samples had been examined in all but one of them.

Outbreaks of $C$. parapsilosis were less common; this pathogen was involved in only 22 of the 2,112 outbreaks in the database, eight of which had occurred in an NICU setting (Table 3 ).

Overcrowding, understaffing, and a discrepancy between workload and resources have been reported to be associated with unfavorable patient outcomes: increased numbers of HAIs [151, 152] and mortality [153, 154]. Understaffing has also been linked to several hospital outbreaks, including those caused by resistant microorganisms [155-158]. Measuring workload is difficult; at least the severity of illness of the patients (case-mix), the educational level of the staff (HCW skill-mix) and organizational factors (e.g., working shift schedule, mental stress) are likely to affect the workload [159]. In single NICU studies, various crude approaches have been used, such as calculating nurse-to-patient ratios [155] or nurse-hours per patient per day [151], and calculating the proportion of extra staff [156]. Additionally, the number of potentially hazardous contact routes, not the nurse-topatient ratio alone, could be a deciding factor in overcrowding situations; cohorting the nurses so that each nurse cares for a certain cohort of patients helps to minimize staff-patient contact [160].

\subsubsection{Hand hygiene and cross-transmission}

Several studies have demonstrated the exogenous route of infection in ICUs by using the molecular genotyping of pathogens (Table 4). The proportion of identical isolates in these studies was between $9 \%$ and $72 \%$, showing the prominent role of cross-transmission and suggesting that improvement in infection control procedures could significantly reduce the number of HAIs. The role of hand hygiene is crucial and has been recognized as the single most important preventive measure [161]. Nevertheless, compliance with hand hygiene procedures is often poor, at only $30 \%$ $40 \%$ [162-165]. Compliance seems to vary depending on several issues: women tend to comply more often than men, and nurses more often than physicians or nursing assistants [162, 166]. In addition, working in an ICU or wearing gloves has been observed to be a risk factor for lack of compliance with hand hygiene [162]. Even if wearing gloves has been associated with a reduction in HAI rates, inappropriate use, such as failure to remove the gloves after patient contact or between dirty and clean body site care or ignoring hand hygiene after glove removal, is likely to enhance the transmission of pathogens [167, 168]. Alcohol-based hand rubs have been demonstrated to cause less skin irritation than the traditional washing 


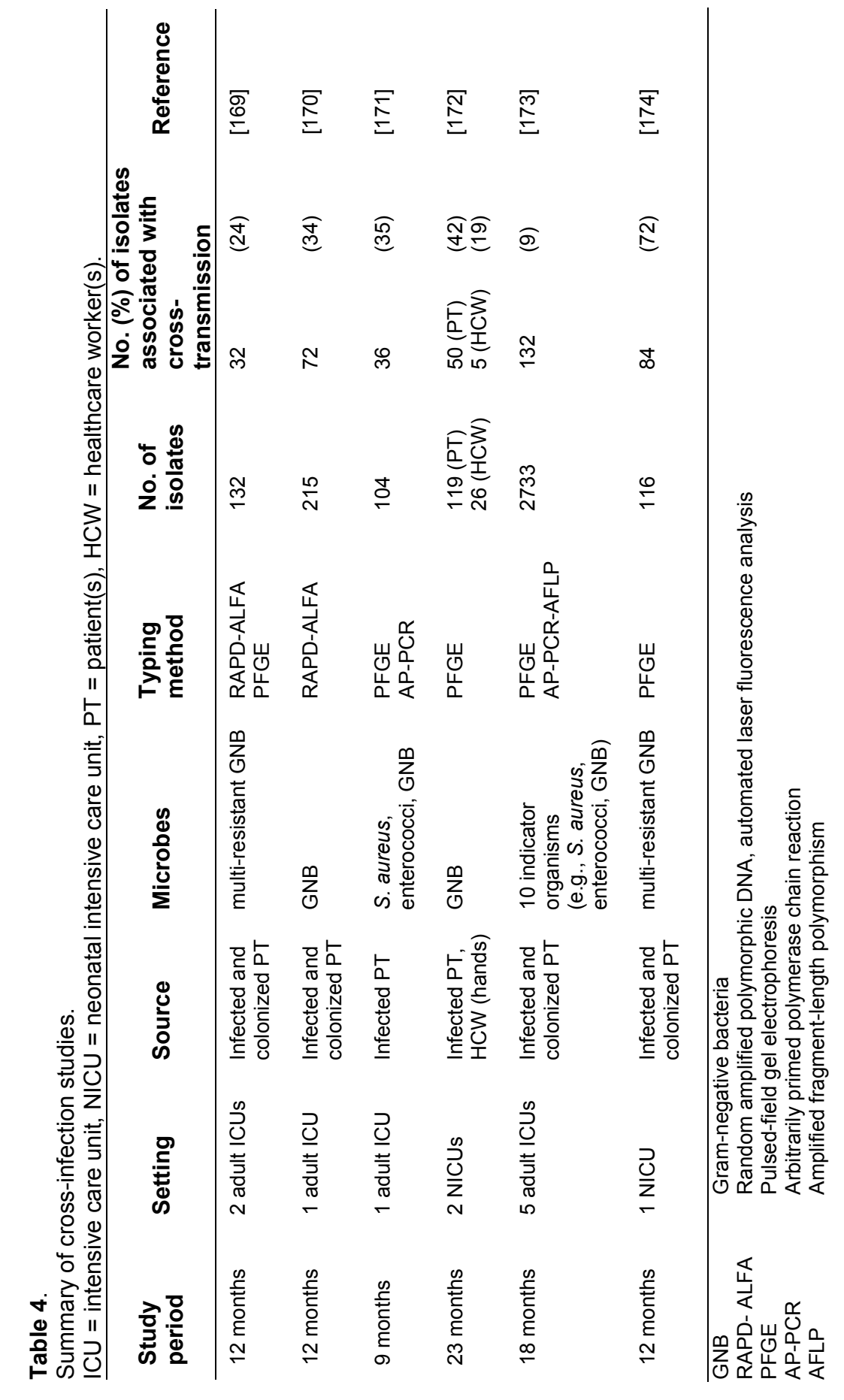


with soap and water $[175,176]$. Use of hand rubs has been reported to result in higher compliance with hand hygiene $[177,178]$, in greater reduction in hand contamination compared with antimicrobial soaps $[179,180]$, and in reduction in nosocomial transmission of resistant bacteria [181]. Therefore, alcohol-based hand rubs are considered as the method of choice for decontaminating hands in clinical situations nowadays; handwashing with soap and water is, however, recommended whenever the hands are visibly dirty [161].

The most common causes of lack of compliance with hand hygiene that were mentioned in interviews with HCWs included poor access to hand hygiene supplies, skin irritation caused by hand hygiene agents, interference with the patient-nurse relationship, the wearing of gloves, lack of knowledge, and forgetfulness [162]. A survey conducted to assess the knowledge, beliefs and practices of HCWs in a large NICU in the US showed a discrepancy between knowledge and practice: $96 \%$ of HCWs believed that sterile techniques, 91\% believed that gloves, and 99\% thought that hand hygiene prevents HAIs in CVC care, but only $67 \%$ used sterile barriers in CVC insertions, $81 \%$ reported routine hand hygiene, and $76 \%$ reported wearing gloves. Moreover, the role of rings and artificial or long fingernails in increasing the risk for HAIs was not well known: $61 \%$ wore at least one ring, $44 \%$ wore long fingernails, and $8 \%$ wore artificial fingernails at work [182]. The NICU staff may also oppose eliminating use of jewelry and artificial nails, because changes in these practices extend beyond the workplace. Evidence linking HAIs with wearing artificial fingernails or hand jewelry can be helpful in achieving compliance [183].

Hand hygiene compliance rates can be improved by educational campaigns [163, 184, 185]. The Hawthorne effect, first described in electric factory workers as early as in the 1930s [186], refers to the tendency of people under observation in a study context to behave differently from the way they otherwise do and may explain why the effect of educational campaigns could likely be short-lived [184]. Regular interaction between infection control and nursing staff on wards is important and may promote stricter adherence to hand hygiene than occasional campaigns [163, 183, 187, 188]. 


\subsection{SURVEILLANCE OF PEDIATRIC HEALTHCARE- ASSOCIATED INFECTIONS}

\subsubsection{Purpose and objectives of surveillance}

Surveillance, "the ongoing, systematic collection, analysis, and interpretation of health data essential to the planning, implementation, and evaluation of public health practice, closely integrated with timely dissemination of these data to those who need to know" [189], is a cornerstone of infection control. Surveillance enables the establishment of baseline HAI rates and the detection of outbreaks, assists in selecting treatment and prevention strategies, offers the possibility to assess the impact of control measures, renders comparisons between units or hospitals possible, and provides tools for convincing administrators of the need for additional resources $[28,190]$.

The Study on the Efficacy of Nosocomial Infection Control (SENIC), conducted in the 1970s, reported effective surveillance programs to include the following essential components: organized surveillance and control activities, qualified personnel (trained infection control physicians and nurses) to conduct the surveillance, and a system for reporting infection rates to clinicians; implementing such a program with these components reduced the hospitals' infection rates by $32 \%$ [191]. The component of organized surveillance includes numerous aspects: assessing the population and selecting the outcome or process for surveillance to identify the most appropriate methods, using surveillance definitions consistently, and systematically collecting and managing as well as regularly analyzing the data in order to promptly identify possible problems [192, 193]. Furthermore, risk stratification (i.e., subdividing the population into groups with similar characteristics) is recommended [193]. Without stratification, the heterogeneity of the study population could render comparisons between units, or over time in a single unit, invalid or misleading. For example, stratification by birth weight categories is recommended for NICU patients, because low birth weight has proved to be a significant risk factor for HAIs [10, 11, 64, 74, 76, 79, 80, 194].

National surveillance systems for HAIs have been developed during the past decades in many developed countries. The first of them, the NNIS, began in the US in 1970, when selected acute care hospitals began reporting their HAI surveillance data to the national database established and maintained by the Centers for Disease Control and Prevention (CDC). The participation of hospitals was voluntary and confidential [195]. In the beginning, the NNIS surveillance was hospital-wide, meaning all patients were monitored for HAIs, infections at all sites were included, and overall HAI rates were calculated [196]. In 1986, three additional standardized protocols were introduced to 
address the limitations of laborious hospital-wide surveillance (see also 2.3.4): the intensive care unit, the high-risk nursery, and the surgical patient components were initiated. In 2005, the NNIS was merged with two other healthcare surveillance systems at the CDC, the Dialysis Surveillance Network and the National Surveillance of Healthcare Workers, to establish the National Healthcare Safety Network (NHSN), which has both a Patient Safety and a Healthcare Personnel Safety surveillance component [197]. Within the Patient Safety component, the data are grouped into three module protocols: the Device-associated module, the Procedure-associated module, and the Medication-associated module.

During the 1990s, national or regional networks for HAI surveillance, most of which were based on the NNIS model, were established in many European countries as well as in Canada and Australia [198]. The Hospitals in Europe Link for Infection Control through Surveillance (HELICS) [199] was founded in 1994 to facilitate a standardized approach to HAI surveillance and to encourage the development of new surveillance programs for HAIs [200]. Two common surveillance protocols have been agreed upon within HELICS: surveillance of ICU-acquired infections and surveillance of SSIs [199-201].

\subsubsection{Surveillance definitions}

Standard surveillance definitions and protocols are essential for surveillance systems [202]. The definitions do not define clinical illness, but are used for credible and consistent case finding and ascertainment across institutions [203]. The surveillance definitions should be exact, easy to use, and unambiguous, and should allow different observers to obtain the same results [192]. To compare the results with those of other surveillance systems, the definitions should be similar to those used by the other systems. Most national surveillance systems have adopted the CDC definitions, often with local modifications. These modifications, however small, may affect SSI rates considerably [204, 205]. The CDC definitions of laboratoryconfirmed BSIs and clinical sepsis (Table 5) include specific criteria for patients under one year of age. However, the definitions may not always be appropriate for identifying HAIs in neonates due to certain special physiological features $[6,206]$. Moreover, a time limit of three days is often used when defining neonatal nosocomial BSIs; early-onset infections are excluded because they are likely to be acquired vertically (from the mother), rather than horizontally (from the hospital environment) $[10,206]$. The CDC definitions of SSI appear in Table 6. 


\title{
Table 5.
}

The Centers for Disease Control and Prevention definitions of laboratory-confirmed bloodstream infections and clinical sepsis [195].

\author{
Laboratory-confirmed bloodstream infection \\ Laboratory-confirmed bloodstream infection must meet at least one of the following criteria: \\ Criterion 1: $\quad$ Patient has a recognized pathogen cultured from one or more blood cultures \\ and \\ organism cultured from blood is not related to an infection at another site. \\ Criterion 2: $\quad$ Patient has at least one of the following signs or symptoms: fever $\left(>38^{\circ} \mathrm{C}\right)$, chills, \\ or hypotension \\ and \\ at least one of the following: \\ a. Common skin contaminant (e.g., diphtheroids,Bacillus sp., Propionibacterium \\ sp., coagulase-negative staphylococci, or micrococci) is cultured from two or \\ more blood cultures drawn on separate occasions \\ b. Common skin contaminant (e.g., diphtheroids, Bacillus sp., \\ Propionibacterium sp., coagulase-negative staphylococci, or micrococci) is \\ cultured from at least one blood culture from a patient with an intravascular \\ line, and the physician institutes appropriate antimicrobial therapy \\ c. Positive antigen test on blood (e.g., Haemophilus influenzae, Streptococcus \\ pneumoniae, Neisseria meningitidis, or group B Streptococcus) \\ and \\ signs and symptoms and positive laboratory results are not related to an \\ infection at another site.
}

Criterion 3: $\quad$ Patient $\leq 1$ year of age has at least one of the following signs or symptoms: fever $\left(>38^{\circ} \mathrm{C}\right)$, hypothermia $\left(<37^{\circ} \mathrm{C}\right)$, apnea, or bradycardia and

at least one of the following:

a. Common skin contaminant (e.g., diphtheroids, Bacillus sp., Propionibacterium sp., coagulase-negative staphylococci, or micrococci) is cultured from two or more blood cultures drawn on separate occasions

b. Common skin contaminant (e.g., diphtheroids, Bacillus sp., Propionibacterium sp., coagulase-negative staphylococci, or micrococci) is cultured from at least one blood culture from a patient with an intravascular line, and physician institutes appropriate antimicrobial therapy

c. Positive antigen test on blood (e.g., H. influenzae, S. pneumoniae, N. meningitidis, or group B Streptococcus) and signs and symptoms and positive laboratory results are not related to an infection at another site. 
Table 5 (continued).

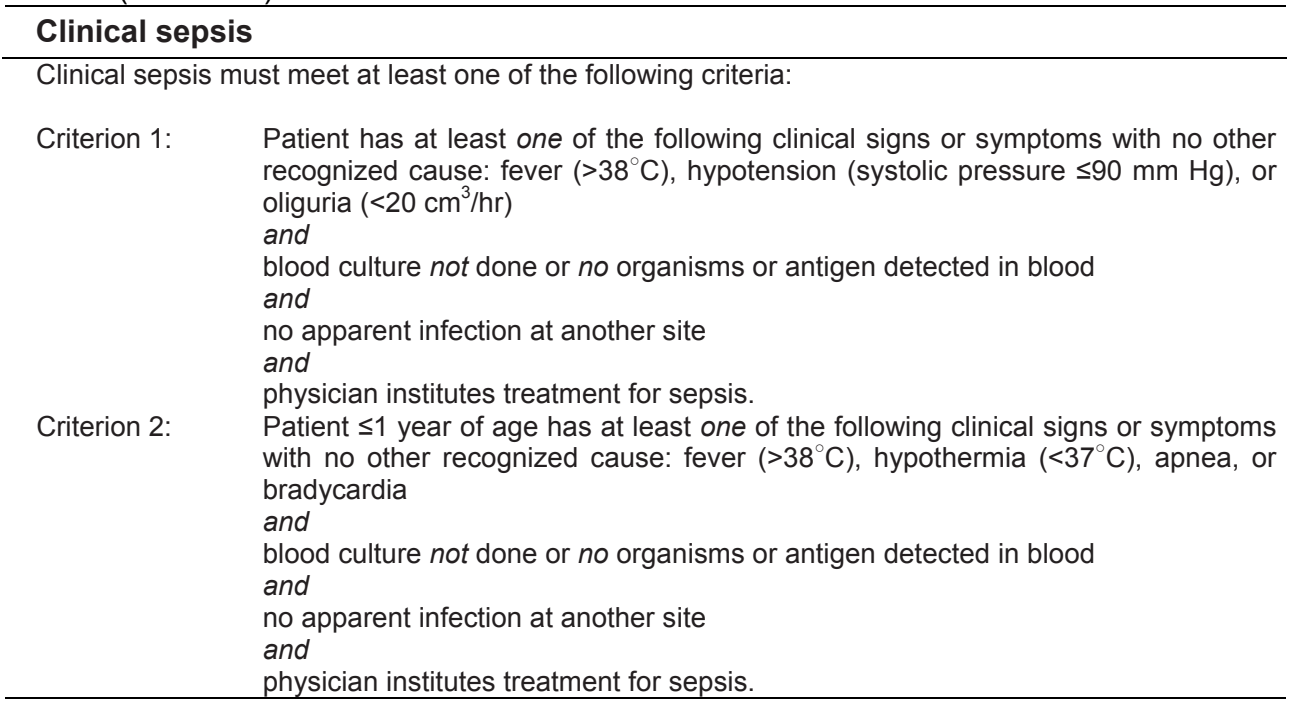

\subsubsection{Case finding and ascertainment}

Identification of HAIs requires the use of multiple information sources, as the definitions include both clinical and laboratory information. The time required for data collection depends on the case finding method, and the sensitivities of the different methods vary $[192,207]$. Thus, to ensure the comparability of HAI rates within a surveillance system, the methods for case finding and ascertainment should be defined [208]. For instance, the sensitivity of a systematic chart review of all patients - a very time-consuming method - has been reported to be as high as $94 \%$ [209-211], but to drop to $71 \%$ if the chart review is selected based on the ward liaison and a review of laboratory reports [212]. The sensitivity of a single method may also vary depending on infection type or patient subpopulation. When prevalence study data on 15,000 patients from 72 hospitals were investigated using either microbiology reports or antibiotic administration as indicators, $>95 \%$ of the patients with pneumonia, urinary tract infection or BSI were identified, and $>95 \%$ of the HAIs of ICU patients were found. However, for SSIs the sensitivity of these indicators was $<90 \%$, and the overall sensitivity was as low as $<80 \%$ in some hospitals [213]. 
Table 6.

The Centers for Disease Control and Prevention definitions of surgical site infections [214].

Superficial incisional SSI

A superficial SSI must meet the following criteria:

Infection occurs within 30 days after the operative procedure

and

involves only skin and subcutaneous tissue of the incision

and

patient has at least one of the following:

a. Purulent drainage from the superficial incision

b. Organisms isolated from an aseptically obtained culture of fluid or tissue from the superficial incision

c. At least one of the following signs or symptoms of infection: pain or tenderness, localized swelling, redness, or heat, and superficial incision is deliberately opened by surgeon, unless incision is culture-negative

d. Diagnosis of superficial incisional SSI by the surgeon or attending physician

Deep incisional SSI

A deep incisional SSI must meet the following criteria:

Infection occurs within 30 days after the operative procedure if no implant* is left in place or within 1 year if implant is in place and the infection appears to be related to the operative procedure

and

involves deep soft tissues (e.g., fascial and muscle layers) of the incision

and

patient has at least one of the following:

a. Purulent drainage from the deep incision but not from the organ/space component of the surgical site

b. A deep incision spontaneously dehisces or is deliberately opened by a surgeon when the patient has at least one of the following signs or symptoms: fever $\left(>38^{\circ} \mathrm{C}\right)$ or localized pain or tenderness, unless incision is culture-negative

c. An abscess or other evidence of infection involving the deep incision is found on direct examination, during reoperation, or by histopathologic or radiologic examination

d. Diagnosis of a deep incisional SSI by a surgeon or attending physician

Organ/space SSI

An organ/space SSI must meet the following criteria:

Infection occurs within 30 days after the operative procedure if no implant* is left in place or within 1 year if implant is in place and the infection appears to be related to the operative procedure

and

infection involves any part of the body, excluding the skin incision, fascia, or muscle layers, that is opened or manipulated during the operative procedure and

patient has at least one of the following:

a. Purulent drainage from a drain that is placed through a stab wound into the organ/space

b. Organisms isolated from an aseptically obtained culture of fluid or tissue in the organ/ space

c. An abscess or other evidence of infection involving the organ/space that is found on direct examination, during reoperation, or by histopathologic or radiologic examination

d. Diagnosis of an organ/space SSI by a surgeon or attending physician

* A nonhuman-derived implantable foreign body (e.g., prosthetic heart valve, nonhuman vascular graft, mechanical heart, or hip prosthesis) that is permanently placed in a patient during surgery. 
In practice, case finding is usually performed by infection control nurses (ICNs), who regularly review the data sources available (microbiology reports, patient records, ward notifications) $[28,195]$. By comparing the findings of each infection to the HAI definitions, they conclude whether the criteria have been fulfilled (i.e., whether a HAI has occurred). To obtain high quality data, ICNs require regular training, counseling, and updating of their skills [203, 215]. Case finding, however, depends exclusively on the data present in the hospital information system, and differences in institutional practices (e.g., culturing activity) render standardization of data collection very difficult [216].

Postdischarge surveillance of SSIs has proved to be necessary in many surgical operation types: while the length of postoperative hospitalization has decreased, the proportion of SSIs appearing after discharge has increased [108, 217-219]. Different methods have been used for postdischarge case finding: direct observation of the wound by a $\mathrm{HCW}$, patient questionnaires, telephone interviews, review of operating logs to examine surgical revisions, examination of hospital readmission data, and review of pharmacy data [220]. However, the existing research evidence has not yet identified the best method for postdischarge surveillance of SSI. No studies on postdischarge SSI surveillance in pediatric patients were available for this review.

\subsubsection{Data analysis}

HAI frequency can be measured with prevalence or incidence rates. To achieve meaningful rates, the time period for the numerator (i.e., the number of times an event has occurred) and the denominator (i.e., the population from which those experiencing the event were derived) must be identical. Prevalence measures the active number of HAIs (new or old) present at a specified point in time or during a specified period of time. The most common measures of incidence are crude cumulative incidence (i.e., the number of new cases of HAI per 100 admissions or discharges); crude incidence density, a.k.a. the adjusted infection rate (i.e., the number of new cases of HAI per 1,000 patient-days); the specific incidence density, which is adjusted for extrinsic risk factors such as exposure to devices (CVC, ventilator) or a provider (ICU); and the adjusted incidence density, which is adjusted for intrinsic host factors [28, 192, 193, 195].

The first surveillance programs collected hospital-wide HAI data and yielded crude overall HAI incidence rates using the number of admissions or discharges and patient-days as denominators [196]. This approach ignored the fact that the risk factors contributing to the development of each HAI type will likely differ [221]. The use of site-specific HAI rates controls for this problem, but provides no adjustment for variations in patients' intrinsic and extrinsic infection risks (e.g., a high BSI rate in a NICU could be due to a large number of VLBW infants with 
CVCs, not necessarily to an inadequate BSI prevention program) [196]. To control for patients' extrinsic risk factors, the numerator should represent the number of infections that occur in patients exposed to a risk factor (for example CVCassociated BSIs, i.e., patients with a CVC at the time of the BSI during a defined time period), and the denominator should measure the exposure to that particular risk factor in the entire population studied (e.g., the number of CVC days during the same time period). To control for patients' intrinsic risk factors, the rates should be stratified according to patient subgroups with similar characteristics (e.g., the CVCassociated BSI rates among neonates with birth weights $<1500 \mathrm{~g}$ or among those born before 32 weeks of gestation).

\subsubsection{Surveillance feedback}

Surveillance results should be reported systematically to ensure information sharing with those healthcare providers capable of initiating patient care improvement [193]. At least the infection control committee as well as key persons in each clinical service, in the nursing administration, and in the hospital administration should be informed. Communication should occur on a regular basis, and the reports should be simple enough so that the target audience can understand the message in a few seconds. Comparing rates with benchmark data is important in terms of helping the audience to determine whether their rates are too high. Confidentiality for patients and employees must be maintained when reporting results. Intensified reporting, such as weekly reporting catheter-related BSIs to the ICU, may also serve as an intervention to reduce HAIs [28].

The SENIC study showed that $6 \%$ of HAIs could be prevented with minimal infection control efforts, and stated that a third of HAIs could be prevented with well-organized infection control programs [191]. No such large and systematic cohort studies have been published after SENIC. However, a systematic review of recent multi-modal intervention studies and studies assessing cross-transmission concluded that at least $20 \%$ of HAIs may be preventable and that, depending on the setting, baseline infection rates, and type of infection, the reduction effect ranged from $10 \%$ to $70 \%$ [29].

The European surveillance networks have been shown to be effective in preventing HAIs, reporting reductions of $20 \%-29 \%$ in SSI rates and $24 \%-57 \%$ in ICU-related HAI rates [222]. For instance, the German HAI surveillance system (KISS) has reported a $29 \%$ reduction in relative risk (RR) for VAP, a $20 \%$ RR reduction for CVC-related BSI, and a 28\% RR reduction for SSI in ICUs (NICUs excluded) and surgical departments over a three-year period of active surveillance [223]. In the NICUs participating in KISS, the BSI rate (both laboratory-confirmed and clinical sepsis) decreased $24 \%$ overall between the first and third year of surveillance [224]. 
It is notable that no interventions other than systematic surveillance (with a feedback report twice a year and a workshop once a year) were introduced in the KISS studies. Thus, the introduction of surveillance likely motivated the HCWs to follow infection prevention measures more carefully, which then led to a decrease in infection rates [225]. Similar findings have also been reported from single NICUs. The introduction of a prevention program in an NICU in Belgium yielded a $71 \% \mathrm{RR}$ reduction for CVC-related BSIs over a four-year period [194]. In an NICU in Pittsburgh, USA, improving CVC care practices decreased RR for a CVC-related BSI by 37\% [226]; similar interventions led to a 55\% RR reduction for all HAIs in an NICU in Singapore [227].

A multidisciplinary collaborative quality improvement project implementing "potentially better practices", conducted in six NICUs participating the Vermont Oxford Network [228], also reported a significant decrease in the overall rate of BSIs (from $23 \%$ to $17 \%$ ) and in the rate of BSIs caused by CoNS (from $22 \%$ to $12 \%$ ) in the project NICUs over the four-year study period. Similar decline was not seen in the 66 other NICUs that participated in the Vermont Oxford Network and served as a comparison group. Unlike the surveillance networks, this study reported BSIs as proportions $(\%$, number of infants with infection per total number of infants), providing thus no adjustment, and only the first BSI episode for each patient was included in the study. However, the BSI definition used was close to the CDC definition of a laboratory-confirmed BSI.

\subsubsection{Public reporting of healthcare-associated infection rates}

Demands for improved quality of health care, including a reduction in adverse events, have increased during the past two decades [229]; in the US, even a claim for zero tolerance to HAIs has been put forth [230]. Mandatory public reporting has been argued to promote overall improvement in the quality of health care by enabling consumers to make conscious choices about their health care based on this information [231]. However, the accuracy of the performance measurement may raise concern: variations in hospital structure (e.g., staffing level, infection control activity, demographic characteristics), care factors (e.g., CVC care practices), and patient factors each directly or indirectly influence HAI outcomes [232]. Underreporting infections may also become a cause of concern, particularly if the pressure of publicly available data is added to a process that already tends to miss cases, as the NNIS evaluation study showed [233]. The process of producing comparable rates requires standardization of these factors: using uniform definitions and surveillance protocols, performing consistent and accurate case finding, controlling patient factors by risk-adjustment methods, and calculating site-specific rates [202, 234], which should be kept in mind when implementing public reporting. 
Several states in the US have implemented a mandatory reporting policy of HAIs since 2003 and to date, the majority of states have introduced legislation for mandatory public reporting [231]. In the UK, surveillance of some HAIs (namely methicillin-resistant $S$. aureus BSIs, Clostridium difficile-associated diseases, glycopeptide-resistant enterococci, and orthopedic SSIs) was made compulsory, including public reporting of the rates [235]. The effectiveness of public reporting in HAI prevention must still be proven as the evidence available to date is inconclusive [231]. However, public and political awareness of HAIs could raise policymakers' interest in infection control, and hopefully also bring more resources into the field. 


\section{AIMS OF THE STUDY}

The purpose of this study was to obtain detailed information on pediatric HAIs at the Hospital for Children and Adolescents (HCA), Helsinki University Central Hospital, the largest children's hospital in Finland, in order to support HAI surveillance and prevention activities in the future.

The specific objectives were:

1. To evaluate the clinical and epidemiologic features of nosocomial BSIs as well as the distribution and antimicrobial susceptibilities of the causative pathogens (I).

2. To describe clusters of $S$. marcescens infections in the NICU between December 1999 and July 2002, to determine whether a connection existed between the clusters, and to identify risk factors for $S$. marcescens infection or colonization (II).

3. To describe a clonal outbreak caused by $C$. parapsilosis in the NICU during a 12-year period, and to study the development of fluconazole resistance in the causative clone during the long-term use of fluconazole prophylaxis (III).

4. To determine the HAI rate among Finnish pediatric patients who underwent open-heart cardiac surgery. We aimed to identify the HAIs contracted during the postoperative hospital stay. A postdischarge study was conducted to determine whether extended surveillance would be needed in this patient group in the future (IV). 


\section{MATERIALS AND METHODS}

A short summary of the study methods, the patients studied, and the HAIs identified in studies I-IV appears in Table 7.

\subsection{DESCRIPTION OF THE HOSPITAL AND THE NEONATAL INTENSIVE CARE UNIT}

All the studies were conducted at the HCA, which is a tertiary care referral pediatric center with ca. 15,000 annual admissions. The hospital provides specialty care in the following pediatric areas: cardiology, gastroenterology, hematology and oncology (a 21-bed ward and an outpatient unit), infectious diseases, intensive care (a 10-bed PICU), neonatology (a 16-bed and an 8-bed NICU providing level III and level II care, and a 16-bed unit providing level II and level I care), nephrology, neurology, pulmonology, and surgery. Some functions, namely the care of serious heart conditions, open-heart surgery, and organ transplants, are nationally centered in this hospital, serving a population of 5.3 million.

The 16-bed NICU, the setting for the outbreak investigations, has approximately 500 annual admissions, of which $25 \%$ to $30 \%$ are VLBW infants. The unit consists of five rooms, each with at least one sink, and hand disinfectant dispensers available at each bed. An alcohol-based hand rub is used before and after any patient contact, and gloves are routinely used during aseptic procedures to avoid contact with secretions during procedures such as endotracheal suction. Blood samples for culture are drawn from a peripheral vessel by venipuncture whenever an infection is suspected. The empirical antimicrobial treatment used for suspected cases of septicemia during the investigations was a combination of ampicillin and netilmicin. All patients with either suspected or verified candidemia were treated with amphotericin B; since June 1999, liposomal amphotericin B was used routinely. 


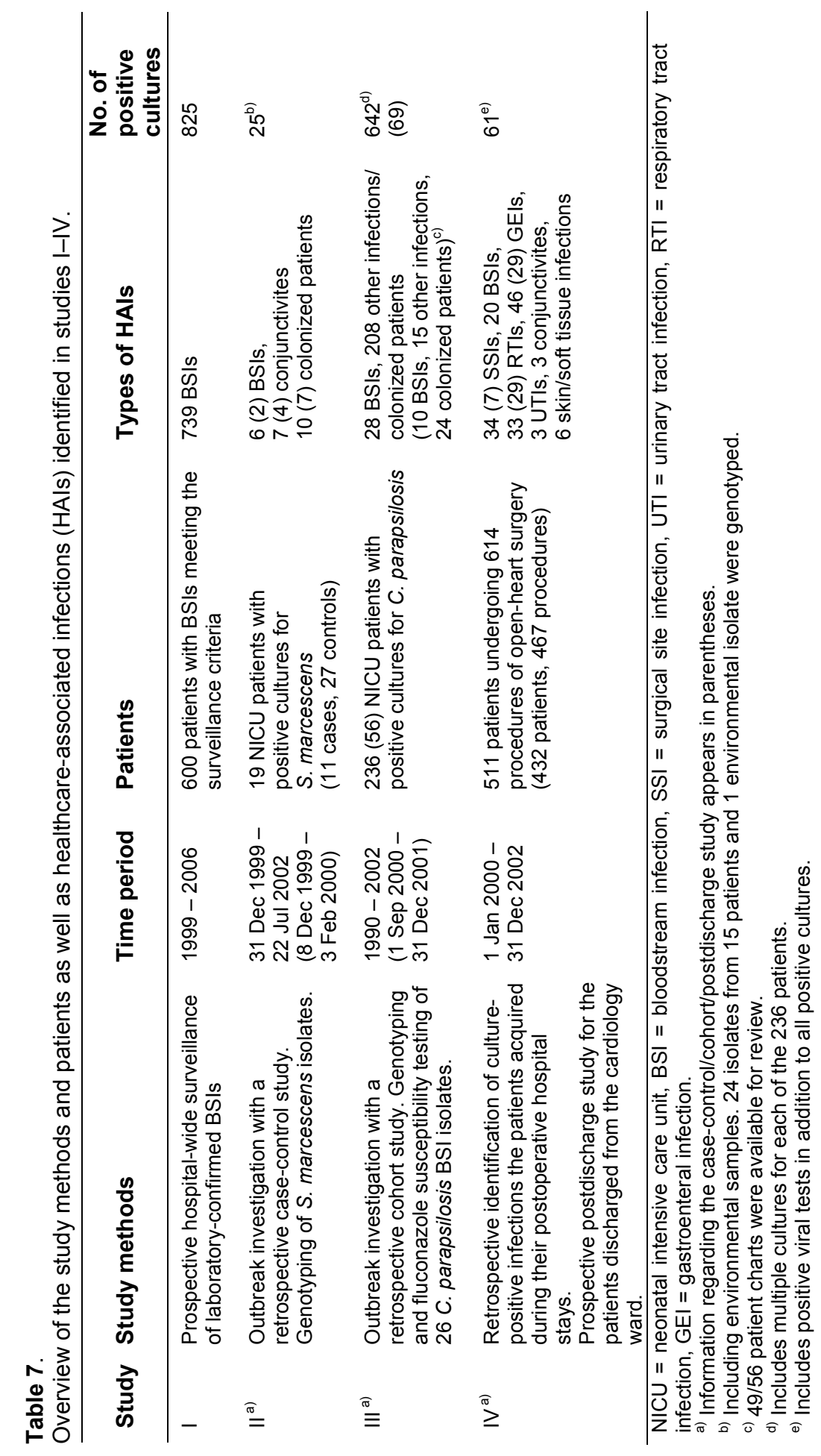




\subsection{SURVEILLANCE METHODOLOGY FOR BLOODSTREAM INFECTIONS OF THE FINNISH HOSPITAL INFECTION PROGRAM (I, IV)}

\subsubsection{In-hospital surveillance of bloodstream infections}

The surveillance module for healthcare-associated BSIs of SIRO began in 1998. In the beginning, four hospitals volunteered to participate; in 2007, ten hospitals were reporting BSIs to SIRO. Hospital participation is voluntary and confidential. Feedback is available for the participating hospitals through the project web site, which can only be accessed with a personal user name and password. Each participating hospital has access to its own data as well as to aggregated data.

The CDC definitions of nosocomial BSI were used, and only laboratory-confirmed BSIs were included in this study [195] (Table 5). BSIs were classified as 'primary' when no focal source other than vascular catheter(s) was identified within 48 hours before the blood culture. 'Secondary BSI' referred to a BSI that developed as a consequence of a documented infection focus at another body site (i.e., the same microorganism was cultured from blood and another body site within a week). 'Polymicrobial BSI' referred to infections in which more than one microorganism was recovered from the blood within a 48-hour period. Newborn BSIs were further classified as 'early-onset' when the first positive blood culture was obtained before the age of three days (72 hours), or as 'late-onset' if it was obtained at the age of three days or later. A written protocol was provided in Finnish, explaining all the definitions in detail.

For case finding, local ICNs regularly reviewed the laboratory database for positive blood culture results. They were also instructed to visit wards every week and to obtain additional information from patient charts and medical and nursing staff. SIRO provided training in surveillance methodology before beginning the surveillance. Additionally, an opportunity to consult the SIRO team staff by phone when needed and meetings at least once a year were provided.

For each patient with a BSI, clinical information and microbiological data were recorded by the local ICNs on a standardized case-record form, which was sent monthly to the national center. The following data were included: the patient's unique national identity number (indicating age and sex), dates of admission and discharge, date of BSI diagnosis, place (ward code) where the BSI was reported, causative microorganisms and their sensitivity to antimicrobial agents, and the underlying conditions (newborn status, hematological/solid malignancy, surgery, presence of a CVC, ICU stay). Newborn status was defined as an age of 28 days or less at the time 
of the blood culture; all patients who entered the operating room were recorded as having undergone surgery. Only patients hospitalized for at least 24 hours in the ICU before the occurrence of BSI were considered to have been exposed to intensive care. All BSIs that became evident during the ICU stay or within 48 hours after discharge from the ICU were defined as related to intensive care.

\subsubsection{Data management in the national database}

The SIRO staff checked the BSI reports for errors and contacted the local ICNs if needed before entering the data into the SIRO database. By using the patients' unique national identity numbers, the data were linked to the National Population Information System to obtain a particular patient's survival at 7 and 28 days from the first positive blood culture.

\subsection{SURVEILLANCE OF HEALTHCARE-ASSOCIATED BLOODSTREAM INFECTIONS (I)}

\subsubsection{Data sources}

SIRO data from 1999 through 2006 were available from HCA. A chart review was performed to obtain information on antimicrobial treatment and the causes of death for patients who died within seven days from the first positive blood culture.

\subsubsection{Analysis and statistics}

Neonatal early-onset infections were excluded from the analysis. Both antibioticresistant and intermediately susceptible organisms were considered resistant when resistance percentages were calculated. Univariate analysis of categorical variables was conducted using the chi-square test with Yates' correction or Fisher's exact test, as appropriate. Continuous variables were analyzed with the Student's $t$ test or the Mann-Whitney $U$ test, depending on the sample distribution. The Kruskal-Wallis test was used to compare several groups. Data were analyzed with Epi Info software (version 6.04, CDC, Atlanta, GA, USA) and SPSS software (version 14.0, Chicago, IL, USA). 


\subsection{OUTBREAK STUDIES (II,III)}

\subsubsection{Outbreak descriptions and case definitions}

Serratia marcescens outbreak (II)

Two blood cultures positive for $S$. marcescens were identified in the NICU in February 2000. Thereafter, samples for screening cultures were obtained from the trachea or pharynx, rectum, and skin of all neonates in the NICU, and neonates with $S$. marcescens infection or colonization were cohorted. Patients in the cohort were cared for using standard precautions, and hand hygiene was emphasized. Nurses were also cohorted whenever possible. The outbreak ceased rapidly during the following month. In September and October 2000, two new S. marcescens cases were detected, the first of which was a BSI. In addition, a third cluster of three $S$. marcescens BSIs was recorded in the summer of 2002 (Figure 2). The two latter clusters ceased spontaneously without the introduction of specific control measures after their detection.

A case-control study was performed to identify risk factors for $S$. marcescens infection or colonization. A review of microbiology laboratory records revealed a positive culture for S. marcescens as early as 31 December 1999; therefore, a case-patient was defined as a patient in the NICU with at least one culture positive for $S$. marcescens between December 1999 and February 2000. A control-patient was defined as a patient admitted to the NICU between 8 December 1999 and 3 February 2000 who stayed in the NICU for at least 72 hours (i.e., to ensure sufficient time for exposure) and yet had no cultures positive for $S$. marcescens. The patients included in the casecontrol study were identified through a retrospective review of the NICU log and the microbiology laboratory reports. For these patients, the length of stay in the NICU, the length of stay in the unit prior to detection of $S$. marcescens, the duration of mechanical ventilation prior to the first isolation (case-patients only; for control patients, the total duration of mechanical ventilation was considered), and exposure to indwelling devices, nutrition, and antibiotics were recorded. Furthermore, information regarding maternal infections prior to delivery as well as the delivery room location was collected from the hospital database.

Environmental samples were taken on 3 February 2000 from all sinks and taps of the two rooms where all of the infected or colonized patients had been located. Additionally, a sample was taken in September 2000 from the breast milk of the mother of a neonate with $S$. marcescens BSI. 
Figure 2.

Patients infected or colonized with Serratia marcescens in the neonatal intensive care unit between December 1999 and July 2002.

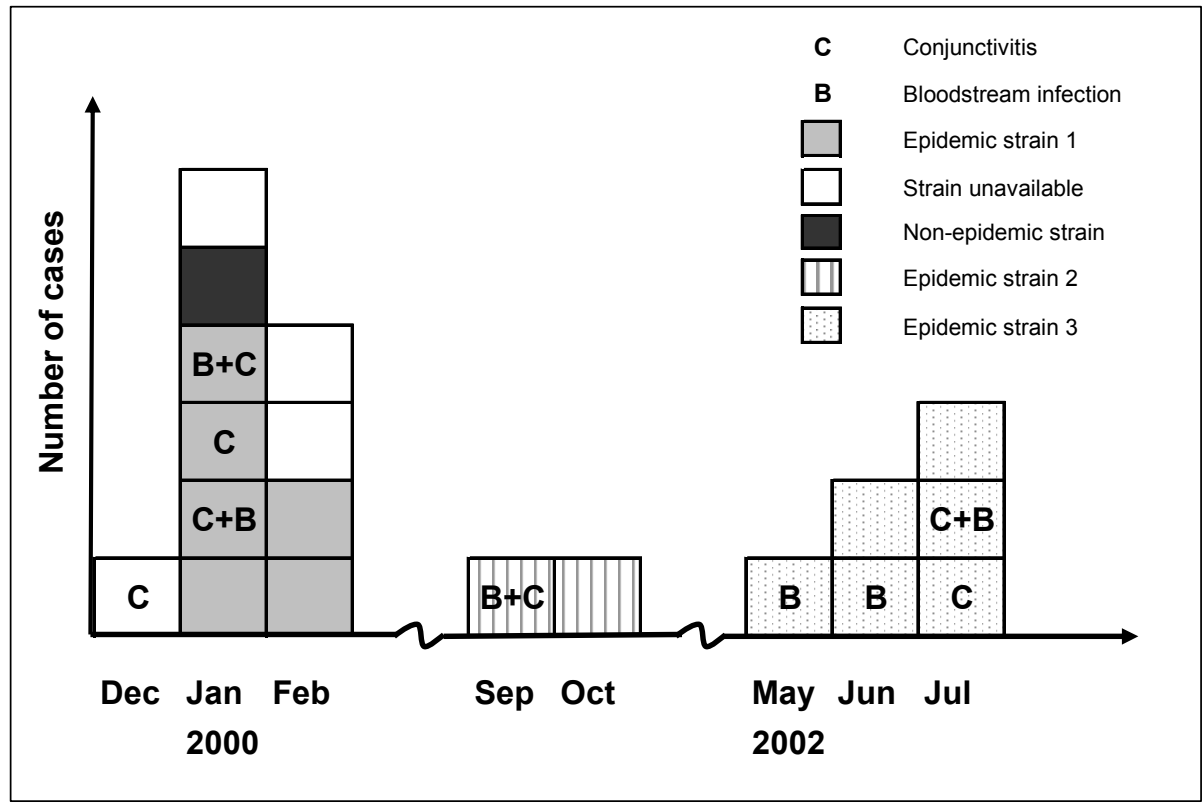

Candida parapsilosis outbreak (III)

The NICU had suffered from nosocomial C. parapsilosis infections since 1989. Fluconazole prophylaxis was introduced temporarily, and the outbreak seemed to cease [146]. Between May 1992 and July 1994, no positive cultures for $C$. parapsilosis were found in the NICU. After this, new cases of $C$. parapsilosis infections or colonizations emerged constantly in the NICU during the years 1994 2000, and in September 2000, the number of patients infected or colonized with $C$. parapsilosis in the NICU began to rise again (Figure 3).

A cohort study was conducted to assess risk factors for C. parapsilosis BSI. All patients treated in the NICU between September 2000 and December 2001 who had at least one positive culture for $C$. parapsilosis were identified through a retrospective review of the NICU $\log$ and the microbiology laboratory reports. Demographic and clinical data on the patients were reviewed, recording the length of stay in the NICU, the length of stay prior to the first positive culture for C. parapsilosis, the duration of mechanical ventilation and nasal continuous positive airway pressure treatment prior to detection of $C$. parapsilosis, exposure to indwelling devices, information on 
nutrition, and the use of antimicrobial agents. Data were also collected on surgical procedures preceding a positive culture for C. parapsilosis, as well as on maternal infections and antimicrobial treatments prior to delivery. The patients were categorized into three groups: i) patients with BSI, ii) patients with clinical signs of superficial infections, and iii) colonized patients. The annual number of admissions and patient-days in the NICU was obtained from the hospital administration.

Environmental samples for culture were taken twice in April 2001 (48 samples from 48 sites) to identify potential inanimate reservoirs, such as incubator ports and interior surfaces, water taps, sinks, ventilatory equipment, and computer keyboards. Air sampling was carried out in two rooms with an SAS Super 100 sampler (PBI S.p.A., Milan, Italy), in which $1 \mathrm{~m}^{3}$ of air was impacted onto glucose-agar plates.

\section{Figure 3.}

Fluconazole use (grams delivered to the unit) and rates of patients with Candida parapsilosis infection or colonization in the neonatal intensive care unit during 1991-2001. $\mathrm{BSI}=$ bloodstream infection.

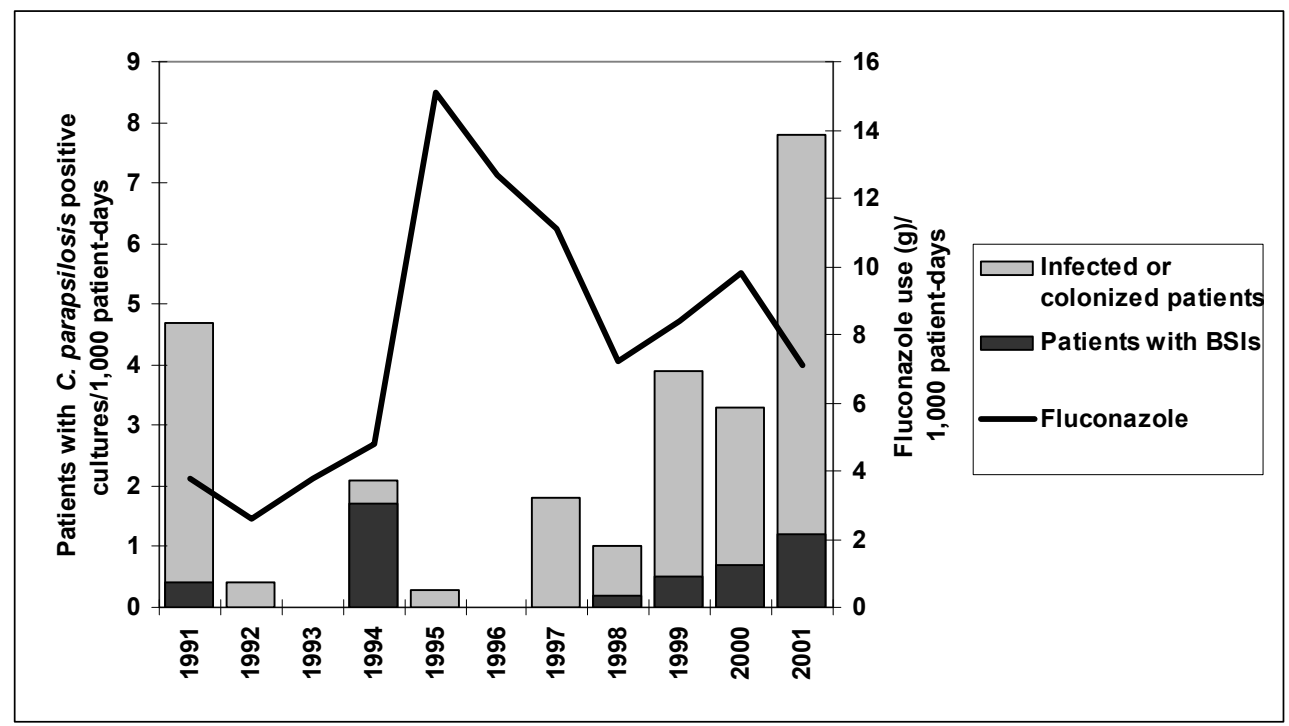

\subsubsection{Fluconazole prophylaxis and use (III)}

During the earlier outbreak, from 1987 to 1991 [146], fluconazole prophylaxis was first introduced in late 1990 with a daily intravenous dosage of $3 \mathrm{mg} / \mathrm{kg}$ of body weight for all infants with a gestational age of $<30$ weeks. In August 1991, the prophylaxis was 
reintroduced with a higher daily dosage $(6 \mathrm{mg} / \mathrm{kg})$ to control the still ongoing outbreak. From December 1991 to February 1993, fluconazole was used with a dosage of $6 \mathrm{mg} / \mathrm{kg}$ twice weekly. After that, infants with birth weights under $1,000 \mathrm{~g}$ were given fluconazole prophylaxis (6 to $12 \mathrm{mg} / \mathrm{kg}$ daily). In late 2000, prophylaxis was extended to cover all infants treated in the NICU, but soon afterwards, the first C. parapsilosis isolates with reduced susceptibility to fluconazole were found, and the prophylaxis was stopped. In November 2002, however, prophylaxis was reintroduced (3 mg/kg daily for all infants born before week 28 of gestation) due to the increased number of $C$. parapsilosis infections. Fluconazole use was assessed based on hospital pharmacy records and calculated as the number of grams delivered to the NICU annually.

\subsubsection{Microbiological methods}

Serratia marcescens outbreak ( I )

The genomic relatedness of $S$. marcescens isolates was analyzed by pulsed-field gel electrophoresis (PFGE). Genomic DNA was prepared in agarose blocks as described previously [236] and digested with $10 \mathrm{U}$ of restriction endonuclease $\mathrm{XbaI}$ (Boehringer, Mannheim, Germany) at room temperature for approximately 18 hours. The resulting DNA fragments were separated with a CHEF-DR III electrophoresis apparatus (BioRad, Hercules, CA, USA) on 1\% Sea Kem agarose (FMC BioProducts, Rockland, ME, USA) using a two-phase program: phase 1 for 10 hours, with initial and final switching times of 5 and 15 seconds, and phase 2 for 15 hours, with initial and final switching times of 15 and 45 seconds, respectively. PFGE profiles differing by fewer than four bands were interpreted as identical or closely related.

Candida parapsilosis outbreak (III)

Blood samples were incubated in pediatric BacT/Alert blood culture bottles (Organon Technica Durham, NC, USA) for six days. Aliquots from positive bottles were Gramstained and subcultured on Sabouraud's glucose agar at $37^{\circ} \mathrm{C}$. All other clinical samples were inoculated on Sabouraud's glucose agar (supplemented with penicillin and streptomycin) and incubated at $28^{\circ} \mathrm{C}$ and $37^{\circ} \mathrm{C}$ for seven days. Yeast isolates were subcultured on Sabouraud's glucose agar and incubated for $24 \mathrm{~h}$ at $35^{\circ} \mathrm{C}$. All isolates were identified by standard methods, including germ tube formation, ID 32C identification panels (bioMerieux, Marcy l'Etoile, France), and morphology on Czapek-Dox Tween 80 agar and on CHROMagar plates (CHROMagar Co., Paris, France). Bloodstream isolates were preserved in $85 \%$ milk-15\% glycerol tubes at $-70^{\circ} \mathrm{C}$ for further characterization.

Environmental swabs were cultured on glucose-peptone agar plates for $96 \mathrm{~h}$ at $30^{\circ} \mathrm{C}$. Yeasts were identified by a standard methodology [237]. 
All stored bloodstream isolates of $C$. parapsilosis obtained from different patients in the NICU between November 1990 and June $2002(n=26)$ were sent to the University of Iowa, USA, for genotyping and antifungal susceptibility testing. This collection contained three BSI isolates from the initial outbreak [146] obtained in 1990 and 1991, and 23 isolates obtained between 1994 and 2002.

All 26 BSI isolates were fingerprinted by Southern blot hybridization with the use of a complex DNA fingerprinting probe Cp3-13 [238] according to the methods described previously $[239,240]$. The digested DNA was electrophoresed in a $0.7 \%$ agarose gel. The $C$. parapsilosis strain $\mathrm{J} 940043$ served as a reference. The gels were transferred to a Hybond $\mathrm{N}^{+}$membrane (Amersham, Piscataway, NJ, USA) by blotting, and autoradiographed after hybridization. Autoradiogram images were digitized into the DENDRON software database [241]. The processed hybridization patterns were then automatically scanned to identify all bands and to link common bands. The patterns of all test isolates were compared in a pairwise fashion, and the similarity coefficient $\left(\mathrm{S}_{\mathrm{AB}}\right)$ between the patterns of every pair of isolates $\mathrm{A}$ and $\mathrm{B}$ was computed. An $\mathrm{S}_{\mathrm{AB}}$ of 0.0 represents total unrelatedness (no common bands) between isolates $\mathrm{A}$ and $\mathrm{B}$, an $\mathrm{S}_{\mathrm{AB}}$ of 1.0 represents an identical match of all bands between isolates $\mathrm{A}$ and $\mathrm{B}$, and increasing values of $\mathrm{S}_{\mathrm{AB}}$ from 0.1 to 0.9 represent increasing levels of similarity.

The antifungal susceptibilities of the $C$. parapsilosis BSI isolates to fluconazole were tested with the Clinical and Standard Laboratory Institute (formerly the National Committee for Clinical Laboratory Standards) M27-A2 broth microdilution method[242].

\subsubsection{Analysis and statistics}

The data were analyzed with Epi Info software (version 6.04b; CDC, Atlanta, GA, USA) (II, III). For categorical variables, proportions were compared using the chisquare test with Yates' correction or Fisher's exact test, as appropriate. The continuous variables were analyzed using the Student's $t$ test or the Mann-Whitney test, depending on the sample distribution. Logistic regression analysis was performed using SPSS software (version 11.0; SPSS, Chicago, IL, USA) to model the odds ratios (OR) with 95\% confidence intervals [56] (II). Pearson correlation coefficients were calculated to assess the relationship between the rates of $C$. parapsilosis BSIs and fluconazole consumption in the NICU over time (III). 


\subsection{HEALTHCARE-ASSOCIATED INFECTIONS AFTER OPEN- HEART SURGERY IN CHILDREN (IV)}

\subsubsection{Data sources}

All patients who underwent open-heart cardiac surgery from 1 January 2000 through 31 December 2002 in the HCA were observed. Procedure-associated data from the Finnish Research Registry of Pediatric Cardiac Surgery [243] were utilized. Procedures were grouped according to the Risk Adjustment in Congenital Heart Surgery (RACHS-1) method, previously used to assess institutional performance by comparing observed and expected short-term mortality rates within risk categories [244]. Additionally, the following data were obtained from the hospital databases: age, gender, length of hospitalization, operation code, type of operation (urgent vs. elective), wound class, American Society of Anesthesiologists (ASA) score, and duration of operation. The NNIS risk index was calculated from these last three.

The HAIs were searched from several sources: from the in-hospital HAI register, from the microbiology laboratory log, and from SIRO (BSIs). A chart review was performed for all identified SSI cases to confirm that the SSI was linked to the surgery and that the CDC definitions were met. The viral epidemics during the study period were identified by reviewing the microbiology laboratory reports.

Patients' families received a standardized postdischarge questionnaire at discharge from the cardiology ward. The follow-up period for SSIs was 30 days after the procedure. Questions were also asked about gastrointestinal and respiratory symptoms with an onset within 72 hours after discharge.

\subsubsection{Analysis and statistics}

For categorical variables, proportions were compared using the chi-square test with Yates' correction or Fisher's exact test, as appropriate. The continuous variables were analyzed with the Mann-Whitney test. Linear-by-linear associations were analyzed using the Cochran-Armitage test for trend. Explanatory covariables with a $P$ value of less than 0.2 in univariate analysis were included in multivariable logistic regression analysis. Akaike and Bayesian Information Criteria for model selection were used. The analyses were carried out using SPSS (version 15.0, SPSS, Chicago, IL, USA). 


\subsection{ETHICAL ASPECTS}

The Ministry of Social Affairs and Health, the National Research and Development Center for Welfare and Health, and the Finnish Data Protection Authority approved the SIRO study plan and authorized the SIRO surveillance (I). The HCA administration provided written consent for the review of the charts of the patients who died within seven days after the positive blood culture. The outbreak investigations (II, III) were conducted as a part of the infection control activities at the HCA, thus no ethics committee approval was required for these studies. The ethics committee of the HCA did, however, approve the research plan of the study for postoperative HAI identification (IV). 


\section{RESULTS}

\subsection{SURVEILLANCE OF HEALTHCARE-ASSOCIATED BLOODSTREAM INFECTIONS (I)}

\subsubsection{Characteristics of patients with bloodstream infections}

A total of 833 nosocomial BSIs in 694 patients were detected during the study period. Of the newborn infections, $94(22 \%)$ were early-onset infections, which were excluded from the analysis. The remaining 739 BSIs in 600 patients were analyzed. The median age of the patients was 48 days; $53 \%$ of them were male. The most common underlying factors were ICU stay (51\%), newborn status (43\%), and surgery $(26 \%)$.

Figure 4.

Annual rates of nosocomial bloodstream infections among patient subpopulations in the Hospital for Children and Adolescents during 1999-2006. HEMA = hematology-oncology unit, $\mathrm{PICU}=$ pediatric intensive care unit, NEONAT = neonatology units, OTHER = all other wards providing acute care.

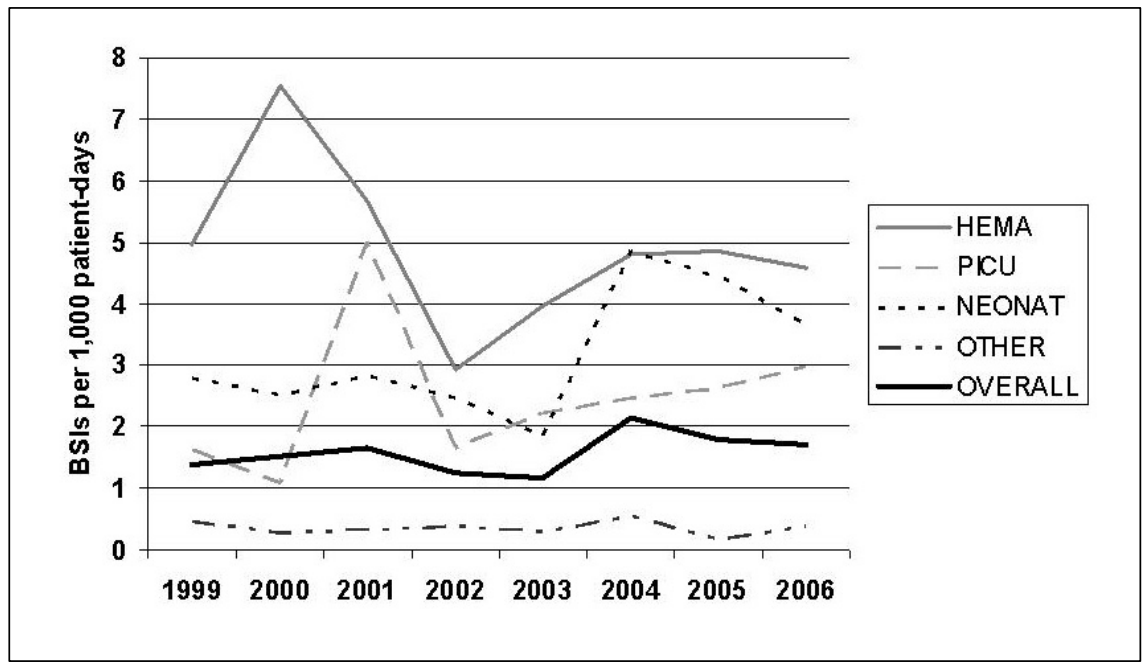


The overall annual nosocomial BSI rate in the hospital was 1.6 infections per 1,000 patient-days (range by year, 1.2-2.1), or 5.7 per 1,000 discharges (range by year, 4.37.1). The rate of BSIs was highest among patients treated in the hematology unit (average annual rate, $4.9 \mathrm{BSIs} / 1,000$ patient-days) and in the neonatology unit (average annual rate, 3.2 BSIs/1,000 patient-days) (Figure 4). Of the BSIs, 699 (95\%) were primary and $40(5 \%)$ were secondary. The skin and subcutaneous tissue $(29 \%)$, the gastrointestinal tract (19\%), and the urinary tract (17\%) were the most common sources of secondary BSIs (unpublished data). CVC data was available for 580 (83\%) primary BSIs and $75 \%$ of those were CVC-associated. In total, 27,279 blood samples were obtained for culture (median 62; range by year, 48-91 cultures per 1,000 patientdays), and 27 BSIs were confirmed per 1,000 blood cultures (range by year, 18-36). No association was found between the annual rates of cultures performed and BSIs detected (Spearman's correlation coefficient $(r)=0.3, \mathrm{p}=0.65$ )

\subsubsection{Microbiological features}

A total of 825 isolates were recovered from blood cultures obtained during the 739 BSI episodes. Of the causative organisms, 627 (76\%; range by year, 67\%-84\%) were Gram-positive, 151 (18\%; range by year, 15\%-27\%) Gram-negative, and 47 (6\%; range by year, $1 \%-13 \%$ ) were fungi. The annual proportions of fungal and Grampositive infections varied significantly ( $p<0.01$ for each) (unpublished data). Three $(0.4 \%)$ of the bacterial isolates were anaerobes. The most common pathogens were CoNS, S. aureus, and Candida species. CoNS were the most common pathogens in all patient groups (Figure 5).

Resistance to methicillin was detected in $86 \%$ of CoNS isolates, but in none of the $S$. aureus isolates. No resistance to vancomycin was found among the staphylococci or enterococci tested. When resistance to ceftazidime served as a marker for the potential presence of extended-spectrum betalactamases, $2 \%$ of both E. coli and Klebsiella isolates were potential carriers of these enzymes.

\subsubsection{Patient outcome}

Information on survival was available for $725(98 \%)$ patients, 19 (3\%) of whom died within a week after the onset of the BSI, and $37(5 \%)$ of whom died within a month. Of the 19 charts of the patients who died within seven days after the first positive blood culture, 18 were available for review. The majority $(13 / 18,72 \%)$ had septicemia as a cause of death. Ten (56\%) patients were newborns, and six of them were born prematurely. Three (12\%) patients had a hematological malignancy and six (33\%) exhibited a congenital condition as an underlying predisposing factor. Fourteen (78\%) 
received appropriate empirical antimicrobial treatment after the clinical BSI diagnosis. Of those whose empirical treatment was inappropriate, two patients had candidemia and only received antibacterial treatment, one had no symptoms of a septic infection and the diagnosis was only apparent post mortem, and one with a BSI caused by cefuroxime resistant Enterobacter cloacae was treated with cefuroxime only.

\section{Figure 5.}

Distribution of the 825 nosocomial bloodstream infection isolates by patient subpopulations. PICU = pediatric intensive care unit.

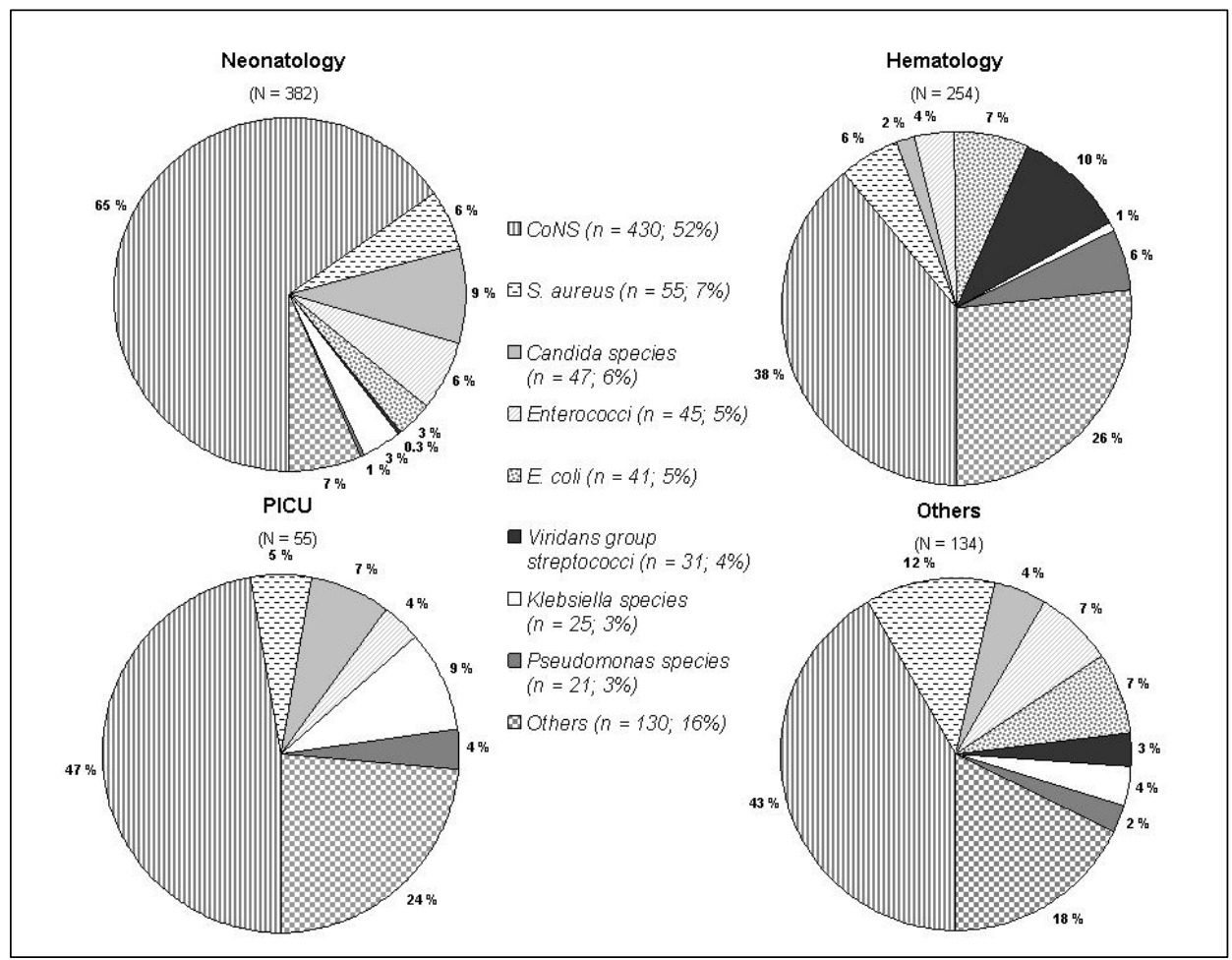

The case-fatality proportions were highest for BSIs caused by Streptococcus agalactiae, Enterobacter species, Pseudomonas, and Candida species (Table 8). The patients who died were more likely to have been admitted to an ICU ( $4 \%$ vs. $1 \%, \mathrm{p}=$ $0.02)$ or to have undergone surgery ( $5 \%$ vs. $2 \%, p=0.03$ ). 


\section{Table 8.}

The most common pathogens among 825 isolates from patients with a nosocomial bloodstream infection (BSI) at the Hospital for Children and Adolescents during 1999-2006, and case-fatality ratios at 7 and 28 days from the date of the first positive blood culture result for a particular patient.

\begin{tabular}{|c|c|c|c|c|c|c|}
\hline \multirow{3}{*}{$\begin{array}{l}\text { Microorganism } \\
\text { Coagulase-negative staphylococci }^{\text {a) }}\end{array}$} & \multirow{2}{*}{\multicolumn{2}{|c|}{$\begin{array}{c}\text { No. (\%) } \\
\text { of isolates }\end{array}$}} & \multicolumn{4}{|c|}{$\begin{array}{l}\text { No. }(\%) \text { of isolates } \\
\text { associated with } \\
\text { case-fatality }\end{array}$} \\
\hline & & & \multicolumn{2}{|c|}{ At day 7} & \multicolumn{2}{|c|}{ At day $28^{*}$} \\
\hline & 430 & $(52.1)$ & 4 & (1) & 13 & (3) \\
\hline Staphylococcus aureus & 55 & $(6.7)$ & 1 & (2) & 1 & (2) \\
\hline Candida species $^{\text {b) }}$ & 47 & $(5.7)$ & 4 & (9) & 6 & (13) \\
\hline Enterococcus species ${ }^{c)}$ & 45 & $(5.5)$ & 1 & (2) & 3 & (7) \\
\hline Escherichia coli & 41 & $(5.0)$ & - & - & 3 & (7) \\
\hline Viridans group streptococci & 31 & $(3.8)$ & 1 & (3) & 1 & (3) \\
\hline Klebsiella species & 25 & $(3.0)$ & 1 & (4) & 1 & (4) \\
\hline Pseudomonas species & 21 & $(2.5)$ & 2 & $(10)$ & 3 & $(14)$ \\
\hline Enterobacter species & 19 & $(2.3)$ & 3 & $(16)$ & 3 & (16) \\
\hline Streptococcus agalactiae & 6 & $(0.7)$ & 1 & (17) & 1 & $(17)$ \\
\hline \multicolumn{7}{|c|}{$\begin{array}{l}\text { Unpublished data } \\
328 / 430(76 \%) \text { Staphylococcus epidermidis } \\
20 / 47(43 \%) \text { Candida albicans, 19/47 (40\%) Candida parapsilosis, } 2 / 47(4 \%) \\
\text { non-albicans, and } 6 / 47(13 \%) \text { non-specified Candida isolates } \\
35 / 45(78 \%) \text { Enterococcus faecalis, } 9 / 45(20 \%) \text { Enterococcus. faecium, and } \\
1 / 45(2 \%) \text { Enterococcus gallinarum }\end{array}$} \\
\hline
\end{tabular}

\subsection{INVESTIGATION OF THE S. MARCESCENS OUTBREAK (II)}

\subsubsection{Description of the clusters and patient volume in the NICU}

During the first cluster, 11 patients with positive cultures for $S$. marcescens were identified during a period of five weeks: one infant with BSI, three with conjunctivitis, and seven who were colonized (Figure 2). The second cluster included one infant with both BSI and conjunctivitis, and one colonized infant four weeks later. The third 
cluster lasted for eight weeks, and included two infants with BSI, two with conjunctivitis and two with $S$. marcescens colonization. The infants had been born in several different hospitals, and no epidemiologic link associated to the place of birth could be found.

The NICU was overcrowded during all of the clusters; the number of patients in the NICU exceeded the official number of beds more than every second day (mean occupation rates $108 \%, 105 \%$ and $118 \%$ for the respective months), and the mean occupation rate of the level III beds was $150 \%$ during the two first clusters. The mean occupation rate in the NICU during the six-month period before the first cluster was 95\%, and during a three-year period covering all the clusters (from June 1999 till May 2002) $97 \%$; the mean occupation rate of the level III beds was $116 \%$ and $110 \%$, respectively (unpublished data). The overcrowding led to a higher patient-to-nurse ratio, because no additional nurses were available.

\subsubsection{Case-control study}

The case-control study included 11 case-patients and 27 control-patients from the first cluster. There were no differences between the two groups in gender, place of birth, and type of delivery. The results of the univariate analysis appear in Table 9. The significant factors found in the analysis were entered into a logistic regression model where only maternal infection (OR, 18.7; CI95, 1.49 to 236.7) remained an independent risk factor associated with $S$. marcescens infection or colonization.

Table 9.

Univariate analysis of factors associated with Serratia marcescens infection or colonization.

\begin{tabular}{lccc}
\hline Factor & $\begin{array}{l}\text { Cases } \\
(\mathbf{n = 1 1 )}\end{array}$ & $\begin{array}{l}\text { Controls } \\
(\mathbf{n}=\mathbf{2 7})\end{array}$ & $\boldsymbol{P}$ \\
\hline Birth weight $(\mathrm{g})^{*}$ & $835(405-2120)$ & $1547(395-4120)$ & 0.01 \\
Gestational age (weeks) & $26(25-33)$ & $31(25-41)$ & $<0.01$ \\
$\begin{array}{l}\text { Duration of mechanical ventilation } \\
(\mathrm{d})^{*}+\end{array}$ & $8(1-46)$ & $2(0-39)$ & 0.02 \\
$\begin{array}{l}\text { Duration of antimicrobial therapy }(\mathrm{d})^{*} \\
\text { Maternal infections prior to delivery }{ }^{\ddagger}\end{array}$ & $8(0-42)$ & $0(0-33)$ & 0.02 \\
\hline
\end{tabular}

Data presented in medians (range)

${ }^{\dagger}$ As measured prior to the first positive culture for $S$. marcescens or discharge from the NICU

${ }^{\ddagger}$ Data presented in numbers (\%); OR 9.3, C195\% (1.5-68) 


\subsubsection{Genotyping}

There were 24 isolates from 15 patients available for PFGE typing: 12 isolates from 7 patients of the first cluster, 6 isolates from 2 patients of the second cluster, and 6 isolates from 6 patients of the third cluster. All but one (11 of 12) of the isolates of the first cluster were identical. Six isolates obtained in the fall of 2000 were identical, but differed from those of the first cluster. The six isolates of the third cluster were indistinguishable from each other, but differed from the isolates of both the first and the second clusters.

One of the four environmental samples taken from a sink during the first cluster tested positive for S. marcescens. PFGE proved that this environmental sample contained the epidemic strain of the first cluster. The breast milk sample obtained during the second cluster also tested positive for $S$. marcescens, but was unavailable for genotyping.

\subsection{INVESTIGATION OF THE C. PARAPSILOSIS OUTBREAK (III)}

\subsubsection{Cohort study}

There were 624 admissions, including 155 VLBW infants, in the NICU during the 16month study period. A total of 56 patients were infected or colonized with $C$. parapsilosis, representing $9 \%$ of all infants treated in the NICU. The study included 10 patients with BSIs, 15 patients with superficial infections (6 with conjunctivitis, 6 with wound infections, 1 with a skin infection, and 2 with urinary tract infections), and 24 patients who were colonized. Six $(60 \%)$ of the 10 patients with BSIs, and four (27\%) of the 15 patients with superficial infections were colonized with $C$. parapsilosis before the infection. The characteristics of the patients with positive cultures for C. parapsilosis appear in Table 10.

The analysis showed no differences between the groups by gender, type of delivery, or mortality. Prematurity, low birth weight, and umbilical catheterization were identified as risk factors for $C$. parapsilosis BSIs. Half (5/10) of the patients with BSIs received fluconazole at the time of the first positive blood culture, as did $27 \%(4 / 15)$ of the patients with other infections at the time of the positive culture. Of the colonized patients, $33 \%(8 / 24)$ received fluconazole at the time of the first positive culture. 


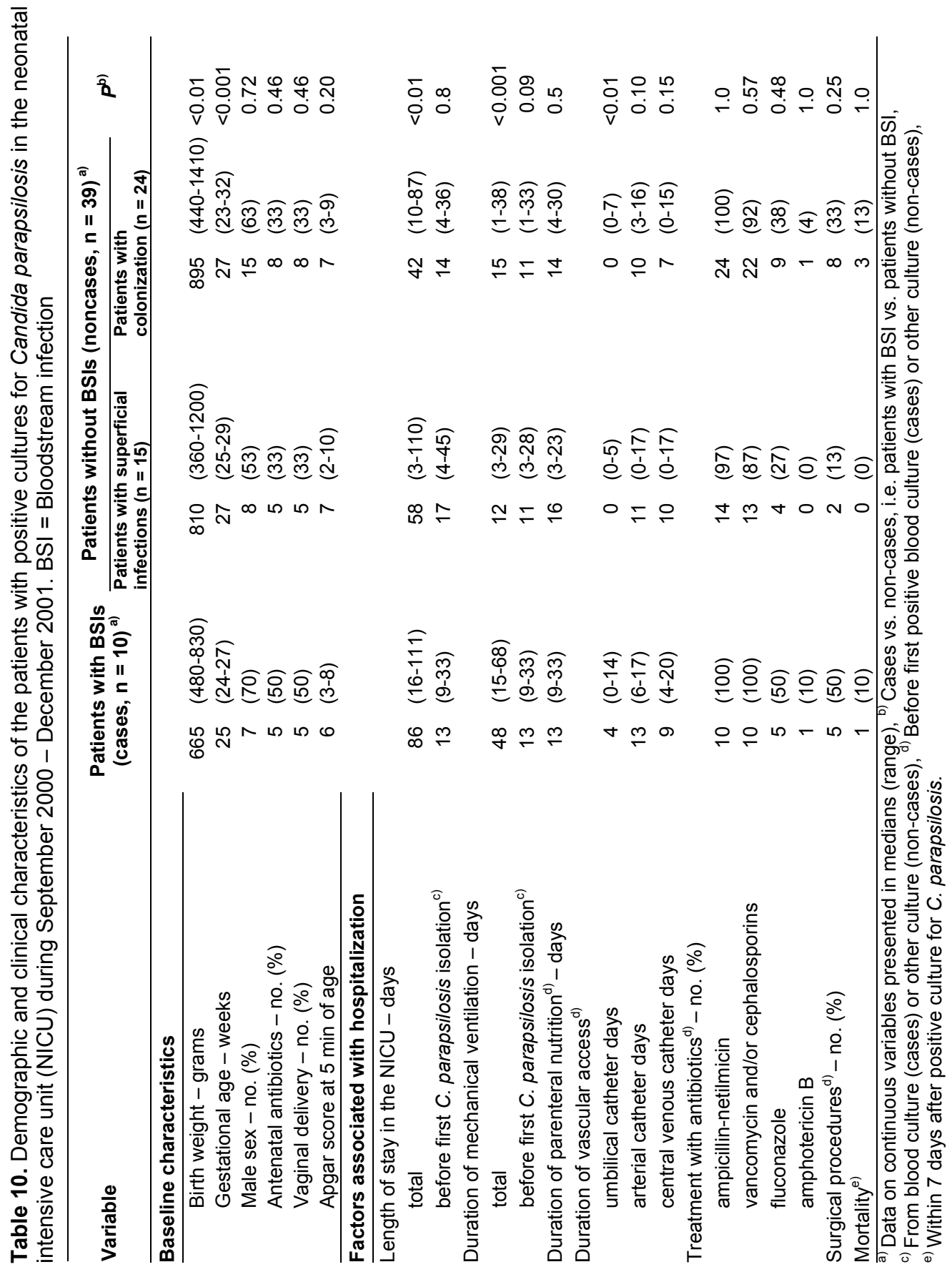




\subsubsection{Fluconazole use and positive Candida cultures}

Fluconazole use in the NICU increased after the initial outbreak in 1989-1991, and remained high from 1994 until 2000, when the first C. parapsilosis strains with reduced susceptibility were detected. When fluconazole use was reduced, the rate of C. parapsilosis infections increased over time (Figure 3). From 1994 to 2001, a negative correlation between fluconazole consumption and the rate of $C$. parapsilosis BSIs emerged $(r=-0.79 ; \mathrm{p}=0.009)$.

During the 12-year period (1991-2002), few sporadic findings of fungi other than $C$. parapsilosis or $C$. albicans were detected. C. parapsilosis was the most prevalent Candida species in the NICU to cause BSIs. Only sporadic cases of $C$. albicans BSIs (zero to one per year from 1990 to 2000 and two in 2001) occurred prior to 2002, when six C. albicans BSIs were detected. No infections caused by Candida krusei or Candida glabrata occurred.

\subsubsection{Genotyping and susceptibility testing}

All 26 BSI isolates were identical in the DNA fingerprinting analysis, and thus represented a single strain of $C$. parapsilosis. When a dendrogram based on the $S_{\mathrm{AB}}$ values that included the 26 isolates from the NICU of the HCA and 16 randomly selected $C$. parapsilosis isolates from a worldwide collection at the University of Iowa was generated, the $26 \mathrm{HCA}$ isolates clustered at an $S_{\mathrm{AB}}$ of 1.00 .

Overall, 19 of the 26 BSI isolates were susceptible (minimal inhibitory concentration, MIC $\leq 8 \mathrm{mg} /$ liter), 5 of 26 were susceptible dose dependent (MIC = 16 to $32 \mathrm{mg} /$ liter), and 2 of 26 were resistant (MIC $\geq 64 \mathrm{mg} /$ liter) to fluconazole. Over time, the initially susceptible isolates derived from a single strain became progressively less susceptible to fluconazole until resistant isolates emerged in the last two years. The proportion of isolates with the less susceptible phenotype was significantly higher among the isolates collected in 2001 and 2002 than among those collected between the years 1990 and $2000(\mathrm{p}=0.02)$.

Of the 48 environmental samples cultured, only one tested positive for $C$. parapsilosis; this sample was obtained from the base of a tap in a room where an infant with a $C$. parapsilosis BSI had been cared. 


\subsection{HEALTHCARE-ASSOCIATED INFECTIONS AFTER PEDIATRIC OPEN-HEART SURGERY (IV)}

\subsubsection{Characteristics of study patients and procedures}

The study included 614 procedures performed in 511 patients, excluding those who died within 24 hours after surgery. The median age at surgery was six months. The distribution of the procedures by the RACHS-1 score appears in Table 11 (unpublished data). The postdischarge study population consisted of 467 procedures performed in 432 patients, 324 (75\%) of whom received the questionnaire.

\subsubsection{Postoperative infections}

A total of 80 HAIs were detected in 66 patients (in-hospital HAI rate, 6.3 per 1,000 patient-days): 27 SSIs, 20 BSIs, 4 pneumonias, 17 gastrointestinal infections, 3 eye infections, 3 urinary tract infections, and 6 skin or subcutaneous tissue infections. The majority (78\%) of the SSIs were superficial; four (15\%) were deep incisional infections and two (7\%) mediastinitis (mediastinitis rate, 0.3 per 100 procedures). The in-hospital SSI rate was 4.4 per 100 procedures. The 20 BSIs, 19 of which were primary (primary BSI rate, 1.5 per 1,000 patient-days), were identified in $19(4 \%)$ patients.

A total of 291 postdischarge questionnaires $(90 \%)$ were returned. Seven superficial SSIs confirmed by a physician or a nurse were identified. Respiratory symptoms within 72 hours after discharge were reported in $29(10 \%)$ of 291 patients, 7 of whom had been readmitted to the hospital. Gastrointestinal symptoms were also reported in 29 patients, 5 of whom had been rehospitalized. The median length of rehospitalization was three days (range, 1 to 8 days). A total of 9 of the patients with respiratory symptoms and 18 of the patients with gastrointestinal symptoms were postoperatively hospitalized during a viral outbreak (caused by respiratory syncytial virus, norovirus or rotavirus) at the ward.

\subsubsection{Risk factors for surgical site infections}

In the univariate analysis, patients with an SSI were younger and smaller and had a longer preoperative stay than that of patients with no SSI. The NNIS risk index score did not stratify the patients, but the SSI rate increased significantly in terms of both ASA and RACHS- 1 scores ( $\mathrm{p}<0.01$ for both). 
Prolonged preoperative stay, the ASA score, and the RACHS-1 score served as explanatory covariables in the multivariable logistic regression analysis. The two models with the best information criteria were used. Preoperative stay $(\mathrm{OR}=2.7$; CI95\%, 1.1-6.6) and ASA (OR = 2.4; CI95\%, 1.1-5.3) were significant risk factors in one model, but in the other model, none of the covariables was significant by itself.

\section{Table 11.}

Surgical procedures by Risk Adjustment in Congenital Heart Surgery (RACHS-1) score [244].

\begin{tabular}{|c|c|c|}
\hline RACHS-1 score & Type of surgery & $\begin{array}{l}\text { No. of } \\
\text { procedures }\end{array}$ \\
\hline \multirow[t]{2}{*}{1} & Atrial septal defect (ASD) & 44 \\
\hline & Others & 8 \\
\hline \multirow[t]{5}{*}{2} & Ventricular septal defect (VSD) repair & 87 \\
\hline & Glenn shunt & 52 \\
\hline & Total repair of tetralogy of Fallot & 36 \\
\hline & ASD and VSD repair & 11 \\
\hline & Others & 35 \\
\hline \multirow[t]{7}{*}{3} & Repair of transitional or complete atrioventricular canal & 40 \\
\hline & Right/left ventricular-to-pulmonary artery conduit & 31 \\
\hline & Total cavo-pulmonary connection (TCPC) operation & 31 \\
\hline & Arterial switch operation & 27 \\
\hline & Valve replacement & 17 \\
\hline & Repair of coarctation and VSD closure & 15 \\
\hline & Others & 60 \\
\hline \multirow[t]{4}{*}{4} & $\begin{array}{l}\text { Arterial switch operation with VSD closure or repair of } \\
\text { subpulmonary stenosis }\end{array}$ & 10 \\
\hline & Repair of total anomalous pulmonary veins $\leq 30$ days of age & 9 \\
\hline & Atrial septectomy & 7 \\
\hline & Others & 22 \\
\hline 5 & Miscellaneous & 3 \\
\hline \multirow[t]{2}{*}{6} & Norwood operation & 40 \\
\hline & Others & 7 \\
\hline No classification & & 22 \\
\hline
\end{tabular}




\section{DISCUSSION}

\subsection{SURVEILLANCE OF HEALTHCARE-ASSOCIATED BLOODSTREAM INFECTIONS}

\subsubsection{Bloodstream infection rate}

Hospital-wide studies on pediatric nosocomial BSIs are scarce; only three such reports were available, a multi-center report from the US [54], one from an Israeli tertiary care center [53], and one from a Mexican general hospital [245]. We found a BSI rate of 5.7 infections per 1,000 discharges, whereas the overall rates of other studies ranged from 5.3 to 29.4 infections per 1,000 discharges. However, direct comparisons of infection rates are difficult due to significant differences in patient populations, in the hospital infrastructures as well as in medical supplies and practices.

Consistent with the previous studies, we found that BSI rates varied widely depending on the patient subpopulations viewed. Despite the overall stability in annual rates, hematology and neonatology units had heavily fluctuating rates which were considerably higher than those of other units (Figure 4). As NICUs generally differ from other units in a children's hospital, and since special attention should be paid to this particular patient group, the national surveillance systems (e.g., NNIS/NHSH and KISS) have developed separate standardized protocols for these high-risk units and provide specific reference data for NICUs to enable comparisons [200]. The patient populations of individual NICUs may differ significantly, and stratification of the infection rates in proportion to gestational age (or birth weight) groups or device days aids in avoiding misinterpretation of the rates.

\subsubsection{Microbiological aspects}

Gram-positive bacteria, especially CoNS, predominated in our study. This finding was in line with the report from the US [54], while Gram-negative pathogens predominated in the other two studies [53, 245]. Neither methicillin resistance in $S$. aureus isolates nor vancomycin resistance in E. faecium isolates was detected during the study. The finding differed from the corresponding rates of the US study ( $16 \%$ and $11 \%$, respectively) [54], but concurred with the national resistance rates: the proportion of methicillin-resistant $S$. aureus isolates among all $S$. aureus BSI isolates was $<1 \%$ during $1999-2003$, and 3\% during 2004-2006, and until the end of 
2006, only six vancomycin-resistant enterococci isolates had been identified in Finland [246, 247].

\subsubsection{Patient outcomes}

The overall mortality rate in our study was $5 \%$, substantially lower than the rates of $9 \%$ to $38 \%$ reported earlier. The case-fatality proportion for most pathogens did not increase after the first week after the BSI onset. However, for Candida infections, the proportion increased from $9 \%$ on day 7 to $13 \%$ on day 28 . All patients in our study who had candidemia and died $(n=6)$ exhibited severe underlying conditions (3 premature newborns, 2 patients with recent open-heart surgery, and 1 with a hematological malignancy). The chart review showed that two of the four patients who died within seven days after the positive blood culture received empirical antimicrobial therapy, which included no antifungal agents. This may have affected the unfavorable outcome, and suggests that the possibility of a fungal infection should be kept in mind when an empirical BSI treatment is introduced in patients with complicated medical conditions. Clinical predictive models have been developed to help the decision making; for example a retrospective multicenter cohort study (including 100 NICUs) concluded that empirical antifungal therapy should be considered for all premature neonates born before week 25 of gestation, for all thrombocytopenic neonates, and for those neonates born between weeks 25 and 27 of gestation who have been exposed to third-generation cephalosporins or carbapenems in the seven days before the blood culture [248].

\subsection{OUTBREAK INVESTIGATIONS (II, III)}

\subsubsection{Source and spread of the pathogens}

No common source or reservoir for the outbreaks was identified other than the infected and colonized infants themselves. The genotyping results confirmed three independent clusters of $S$. marcescens, and that the same strain of $C$. parapsilosis persisted for over a decade in the NICU. Both findings suggest that infected and colonized patients served as reservoirs, and that the pathogens were most likely transmitted horizontally via the hands of the HCWs in the NICU.

The positive environmental cultures (one for S. marcescens, obtained from a sink, and one for $C$. parapsilosis, obtained from the base of a tap) were probably found as a consequence of washing contaminated hands or utensils prior to taking the sample, which further supports the assumption that the pathogen colonized the hands of the 
HCWs. The positive breast milk sample in the second $S$. marcescens cluster could suggest that the milk was a common source for this cluster, but since the strain was unavailable for genotyping, exploring this hypothesis was impossible.

\subsubsection{Risk factors}

Both investigations identified the risk factors commonly associated with HAIs: low birth weight or gestational age, or prolonged need for mechanical ventilation (Tables 9 and 10). The patients with $S$. marcescens infection or colonization had also received antimicrobial agents for a longer time than those without $S$. marcescens, but since the information on antibiotic use for each patient was collected for the entire hospital stay, this was more likely a consequence of the infection rather than a cause. Maternal infection and subsequent treatment with antibiotics prior to delivery was an independent risk factor for $S$. marcescens, as previous studies have also reported $[123,125]$. The selection pressure following maternal antimicrobial treatment may have led to the overgrowth of $S$. marcescens, and thus contributed to the colonization of some of the infants. However, genotyping confirmed that the outbreak occurred mostly due to cross-transmission, which cannot be explained by maternal characteristics or risk factors.

\subsubsection{Role of hand hygiene, overcrowding and understaffing}

Horizontal transmission most likely occurs via the hands of HCWs and thus emphasizes the role of hand hygiene. Improved hand hygiene compliance has been reported to be crucial in controlling, for example, a large outbreak of C. parapsilosis BSIs in adults [249]. Studies have shown adherence to hand hygiene guidelines to be below 50\% usually [162], and the carriage of different types of pathogens on the hands of the HCWs has also proved to be common in NICUs [172, 174] (Table 3).

Overcrowding and subsequent understaffing likely contributed to the spreading of $S$. marcescens (II). Previous studies have also described outbreaks or site-specific infections associated with increased patient-to-nurse ratios in pediatric settings [143, $146,147,149,153]$. The causality between understaffing and HAIs is complex, and defining the optimal patient-to-nurse ratio is difficult; not only the patient case mix and the number of HCWs, but also the HCWs' level of training and their working conditions, including the possible job-related dissatisfaction, affect the outcomes $[147,250,251]$. 


\subsubsection{Emergence of fluconazole resistance in C. parapsilosis (III)}

Horizontal transmission seems to be especially important for $C$. parapsilosis, in contrast to C. albicans, which is usually acquired vertically from the mother [252]. This could be important when considering the implementation of fluconazole prophylaxis. Our data support the findings reported by Kaufman et al. [91] that prophylaxis could be more effective against $C$. albicans than against $C$. parapsilosis. The nosocomial acquisition of the latter may more often involve strains endemic to the NICU and less susceptible to the prophylactic drug used.

The emergence of fluconazole resistance and the increase in the proportions of intrinsically fluconazole-resistant Candida isolates are a matter of concern when prophylaxis is used. Prophylaxis studies conducted in NICUs [91, 94, 101-103] have shown no signs of fluconazole resistance or reduced susceptibility regarding $C$. parapsilosis isolates. Some have hypothesized that this phenomenon is due to the low total fluconazole doses received [91]. However, all of these studies had a considerably shorter study period than ours (up to 6 years vs. 12 years), and resistant isolates were observed in our study only in the last two years, after ten years of continuous fluconazole prophylaxis use. Given that the 26 BSI isolates represented a single genotype, secondary resistance to fluconazole apparently developed after continued exposure to fluconazole.

Large surveillance studies have found no evidence of an overall increase in the rates of fluconazole resistance in populations of C. parapsilosis either [253-255]; only one study showed a slight decrease in the percentage of fluconazole-susceptible $C$. parapsilosis isolates [256]. A systematic review of randomized controlled fluconazole prophylaxis trials suggested that the use of fluconazole prophylaxis significantly increased the risk of colonization by strains with reduced susceptibility to fluconazole, but the risk for invasive disease caused by such strains did not increase [104].

Among the ten patients with $C$. parapsilosis BSIs included in the cohort study, five were receiving fluconazole at the time of the first positive blood culture, and two of these had isolates with reduced susceptibility to fluconazole. Earlier studies have also reported $C$. parapsilosis to cause candidemia during fluconazole prophylaxis, and some of those $C$. parapsilosis strains were reported to be less susceptible to fluconazole [257, 258]. 


\subsubsection{Patient outcomes}

Few patients with invasive $S$. marcescens or $C$. parapsilosis infections died and none of the deaths were attributable to the infections (II, III). Previous studies have reported a high case-fatality rate in similar patient populations $[90,126,129,135-$ $137,151,152,154,159]$. One explanation for the low mortality rate for $S$. marcescens may be the early use of empiric therapy for neonates showing symptoms of septic infections; most of the $S$. marcescens isolates were susceptible to netilmicin, which was used as part of the first-line therapy. Studies have often reported the case-fatality of $C$. albicans infections to be significantly higher than that of $C$. parapsilosis infections $(26 \%-36 \%$ versus $4 \%-7 \%)[10,86]$, and the observed low case-fatality for $C$. parapsilosis is in line with these reports.

\subsection{HEALTHCARE-ASSOCIATED INFECTIONS AFTER OPEN-HEART SURGERY (IV)}

\subsubsection{Impact of postdischarge surveillance}

Only slightly more than half of the HAIs were detected during the hospital stay (overall HAI rate, 23 per 100 procedures; in-hospital HAI rate, 12 infections per 100 procedures). The SSI rate was 5.5 per 100 procedures; $20 \%$ of the SSIs were detected after discharge. As many as $25 \%$ of the patients who reported symptoms of respiratory or gastrointestinal infections were rehospitalized.

Symptoms of gastrointestinal and respiratory tract infections arising immediately after hospitalization were reported in $22 \%$ of the questionnaires and these infections accounted for more than a third of all HAIs detected. This suggests that the impact of postdischarge surveillance on HAI rates was significant. However, postdischarge surveillance is unlikely to help in reducing the nosocomial transmission of viral infections. In-hospital surveillance and early outbreak detection to promote the implementation of appropriate control measures, for example during seasonal viral epidemics, are more likely to be effective tools in controlling these common pediatric HAIs.

\subsubsection{Postoperative infection rates}

The in-hospital patient infection rate of $16 \%$ in our study was relatively low: the overall [in-hospital] rates reported in previous studies were between $16 \%$ and $31 \%$ [22-24]. The SSI rate of 5.5\% (in-hospital SSI rate, 4.4\%) in this study was in line 
with the previous findings (Table 1). The BSI rate detected was relatively low compared to the rates reported earlier [22-24, 259]. The HAI rates, however, were reported differently from study to study, and only the crude patient infection proportion was available for comparison, which is likely to be distorted.

\subsubsection{Risk factors for surgical site infections}

Most earlier studies have reported the finding that preoperative hospitalization for more than two days increased the risk for SSI $[20,22,23]$; only one of them reported no association [21]. The duration of surgery or perfusion time [20-22] and having an open chest after the operation [23, 24] were identified as risk factors for infection in earlier studies, but we found no such association. The NNIS risk index did not stratify our patients according to their risk for SSI, as also described earlier $[112,113]$. A high procedure complexity score and ASA score seemed to be risk factors, but in the multivariable risk factor analysis, the interpretation of the results was equivocal due to the small number of SSIs and correlations between the variables. Thus, the RACHS-1 score may have provided no advantages in SSI risk assessment over the ASA score, and using the RACHS-1 score could simply create extra work.

\subsection{UNRESOLVED ISSUES AND FUTURE CONSIDERATIONS}

\subsubsection{Surveillance of bloodstream infections (I)}

Unlike many other national surveillance networks nowadays, the BSI surveillance data in SIRO is hospital-wide, and no separate surveillance components have been established for NICUs or other ICUs. Thus, systematically collected deviceassociated data (CVC, urinary catheter, or ventilator usage) or birth weight data for NICU patients were unavailable for this study. As many as $75 \%$ of the study patients with primary BSIs had a CVC at the time of the BSI and the CVC usage rates in different HCA units would have been essential for determining the adjusted rates for CVC-associated BSIs. The hospital databases turned out to be incomplete regarding CVC usage data and also our attempts to obtain the existing data failed due to technical problems. Therefore, to adjust the BSI data appropriately for patients' extrinsic and intrinsic risk factors proved impossible, which rendered the assessment of variation in the patient population over time impossible and the annual BSI rates incomparable. Moreover, our NICU data permitted no international comparisons with, for example, the NNIS or the KISS. 
We detected no reduction in the BSI rates during the eight years of surveillance; the overall rate remained fairly stable, but in some units, especially in the NICU, the annual rates fluctuated heavily with an alarmingly increasing trend in the most recent years (Figure 4). This illustrates the limited capability of overall hospitalwide rates to reveal true changes in special patient subpopulations. The baseline rates for the subpopulations could be even more accurate if adjusted data were available. Additionally, adjusting the definitions for special patient groups (e.g., neonates) according to clinicians' expectations could create an atmosphere of confidence, and thus facilitate the process of surveillance data acceptance and usage among clinicians [206]. To improve the quality of the SIRO data regarding NICUs, these issues need to be addressed in the future.

Surveillance success stories have highlighted the importance of regular feedback [223, 229]. Such stories have also been reported from NICUs [194, 224]. Within SIRO, continuously updated surveillance data are available through the project web site; each hospital has access to its own data (both hospital-wide and on the ward level) as well as the aggregated data, which are also presented at annual SIRO meetings. SIRO has no resources for the routine analysis of unit-based data, and therefore can provide no intensified or targeted feedback. Assistance for the local infection control teams is, however, available. This approach seems too weak, but the key question - how to convince the local infection control teams and clinicians to make full use of the SIRO data - remains to be answered. This could be achieved through more specific projects; for example, the validation study for orthopedic SSIs within SIRO [260] seemed to generate interest among the local teams, and SSI rates have decreased over the following years [261]. Similar interventions could prove useful for BSI surveillance as well, especially for special units such as NICUs. For instance, a NICU prevalence study could help to clarify the purpose and means of surveillance for the staff in patient-care, and thereby also help to improve the quality and degree of utilization of the data.

\subsubsection{Limitations regarding data collection (II-IV)}

The outbreak investigations (II, III) were limited due to retrospective data collection: some data were incomplete or missing, depending on what had been recorded in the patient files. Our study design did not allow assessment of the role of the empiric antibiotic policy in the emergence of the outbreaks, because the use of antimicrobial agents in the NICU was not studied comprehensively.

The data of the patients who underwent open-heart surgery (IV) were also retrospectively completed, and thus culture-negative HAIs could not be identified. The coverage of the postdischarge survey was low, only $52 \%$ of the patients with 
open-heart procedures during the study period were recruited, which could suggest that many HAIs with a postdischarge onset were overlooked. Most severe HAIs were likely caught, because those patients would probably have been rehospitalized. The burden of illness caused by viral infections acquired during hospitalization may, however, be even heavier, and the overall HAI rate higher than reported.

The attempt to measure the workload of HCWs (II) was crude, and thus unlikely to be fully descriptive. Proper measurements would, however, require a prospective, well-designed study focused on this complex issue; measures of outcomes more sophisticated than a HAI may also be needed in the future to determine the optimal staff level and mix of skills [150].

\subsubsection{Compliance with infection control guidelines (I-IV)}

CDC guidelines for the prevention of intravascular catheter-related infections [262], first released in 1996 and updated in 2002, provide basic information and evidencebased recommendations on the use of intravascular devices for HCWs who insert catheters and for staff responsible for the surveillance and control of HAIs. Since catheters, especially CVCs, are an important risk factor for BSIs, guidelines for catheter insertion, care, and maintenance should be developed and implemented in all units using CVCs [263]. In addition, enteral feeding should be favored whenever possible to minimize parenteral nutrition and catheter use [264]. The approach to CVC care in practice, however, seems to vary considerably between the units [265, 266]. The Finnish Society for Infection Control has contributed to the publication of a book containing unofficial national guidelines [267] (adapted from the CDC guidelines) on which the local guidelines in Finnish hospitals can be based. A recent survey of 29 Finnish adult ICUs showed that $25 \%$ of the nurses did not know whether such guidelines existed in the ICU, and that only $52 \%$ of them performed CVC care practices according to the guidelines [268].

We performed no monitoring of $\mathrm{HCW}$ compliance with hand hygiene or of CVC care in our studies. Therefore, identifying or rectifying possible problems in these multifactorial areas is beyond the scope of this study. Studying the prevailing practices through observation in the NICU during the outbreaks, for example, could have helped to reduce cross-transmission. An observational study of CVC care practices could also be well-grounded in high-risk units in the future, and should be considered especially, if BSI rates appear to increase. Training material, such as videos, on CVC care could also encourage stricter adherence to the guidelines. Conducting surveillance or other infection control activities makes no sense if no corrective actions are taken; in short, "we have met the enemy and he is us" [269]. 


\section{CONCLUSIONS}

1. Hospital-wide BSI rates remained stable over time, but the overall stability masked the significant variation among patient subpopulations. CVCs were commonly present in primary BSIs. Further studies with adequate data adjustments for patient risk factors are needed to examine in greater detail the subpopulations with the highest BSI rates (neonatology and hematology patients). A systematical evaluation of the prevailing practices, aiming at reduced use of parenteral nutrition and CVCs as well as improved CVC care, might help to reduce catheter-related BSIs.

2. Outbreak investigations showed that horizontal transmission was common in the NICU. Overcrowding and lapses in hand hygiene likely contributed to the spreading of the pathogens. No common source for the outbreaks, other than infected and colonized patients, was identified.

3. The initially susceptible isolates of $C$. parapsilosis derived from a single strain became less susceptible to fluconazole following long-term exposure to the drug. Eventually, resistant subclones were found in the NICU after a decade of continuous fluconazole use.

4. Almost one-fourth of the children who underwent open-heart surgery acquired at least one HAI. All severe HAIs were detected during hospitalization. Viral infections were common and often caused rehospitalization. The postdischarge study identified only superficial SSIs that did not affect the patient outcome. Thus, routine postdischarge surveillance may be unnecessary in this patient group. 


\section{ACKNOWLEDGMENTS}

This study was carried out at the Hospital for Children and Adolescents, Helsinki University Central Hospital, and at the Department of Infectious Disease Epidemiology and Control, National Public Health Institute, during the years 19992006. I wish to acknowledge the Heads of the Hospital for Children and Adolescents, Professor Mikael Knip and Director Veli Ylitalo, as well as the Director General of the National Public Health Institute, Professor Pekka Puska, and the Head of the Department of Infectious Disease Epidemiology and Control, Professor Petri Ruutu, for providing me with excellent working facilities. I am also indebted to Professor Markku Heikinheimo, the Head of Pediatric Graduate School, University of Helsinki, for promoting support for us doctoral students. This work has been supported by grants from the Foundation for Pediatric Research and from the Päivikki and Sakari Sohlberg's Foundation, both of which are gratefully acknowledged.

I express my deepest gratitude to my supervisors Docent Outi Lyytikäinen and Docent Harri Saxén. I sincerely thank Outi for introducing me into the field of infectious disease epidemiology. Her enthusiasm and patient encouragement have taken me through all the practical challenges during the process. Despite her unlimited number of other duties she always has found the time for me and my questions. I am grateful to Harri for initiating this work and for sharing his vast knowledge and clinical expertise in the field of pediatric infectious diseases. He has helped me to focus on the essential questions and reminded me of the clinical point of view. He has also found the time to help me whenever needed. Both Outi and Harri are especially thanked for showing understanding and empathy during the silent phases of this study, the three periods of maternity leave I had during these years.

Docent Liisa Lehtonen and Docent Risto Vuento are warmly acknowledged for the flexible and swift review process of the thesis; their constructive comments and criticism clearly improved this book. I also want to thank Professor Sture Andersson, my tutor appointed by the Pediatric Graduate School, for his support.

I warmly thank all my coauthors and other collaborators, without whom this work would have been impossible. Päivi Luukkainen, MD, PhD, Irmeli Nupponen, MD, $\mathrm{PhD}$, head nurse Sirkka-Liisa Vepsäläinen, research assistant Marita Suni, and the personnel at the neonatal intensive care unit (LK7), as well as the infection control nurses Tuula Salomaa and Leena Simons, Eeva Salo, MD, PhD, and Ms. Marjaana Rasanen at the Hospital for Children and Adolescents are thanked for good collaboration. Docent Heikki Sairanen and Heta Nieminen, MD, are thanked for 
sharing their valuable data collected in the Finnish Research Registry of Pediatric Cardiac Surgery. Professor Martti Vaara, the Head of Division of Clinical Microbiology, Helsinki University Central Hospital (HUSLAB), Eveliina Tarkka, MSc, and Ms. Tarja Komulainen deserve my sincere thanks for providing microbiological data. Docent Jaana Vuopio-Varkila and Saara Salmenlinna, PhD, at the Hospital Bacteria Laboratory of the National Public Heath Institute are acknowledged for genotyping the strains of $S$. marcescens. I thank Malcolm Richardson, $\mathrm{PhD}$, for sharing his knowledge on C. parapsilosis related issues, and Pirkko Koukila-Kähkölä, MSc, for the practical work with the $C$. parapsilosis strains. My special thanks for smooth and swift cooperation go to our collaborators at the University of Iowa, USA, Professor Michael A. Pfaller, Claude Pujol, PhD, David R. Soll, PhD, and Richard Hollis, who took care of genotyping and susceptibility testing of the $C$. parapsilosis strains and greatly helped in the writing process of the original article.

I wish to thank the present and former SIRO team members, Teemu Möttönen, Pirkko Lehtinen, and Niina Agthe for cooperation. I am also grateful to Jukka Ollgren for his statistical advice. Stephen Stalter is acknowledged for the skillful review of the English language of the thesis.

I owe my sincere thanks to all my colleagues at the Hospital for Children and Adolescents and at the National Public Health Institute for creating a stimulating atmosphere and for all the help and support. Special thanks to Anne Sarajuuri, Kaija Mikkola, Pirjo Tynjälä, Ruska Rimhanen-Finne, and Elisa Huovinen.

I thank my godfather Matti Verkasalo, MD, PhD, who apparently had decided that I need to do a PhD degree and first introduced me to Harri - even if I never really asked him to. Matti with his spouse (and my godmother) Anna-Leena have always been there for me, and I am very grateful to them for all the love and support I have experienced throughout my life.

I want to thank all my friends and relatives who have supported and encouraged me during these years. Thank you Hanna and Petri Reijonen, Anna Peitola and Ville Vepsäläinen, Titta and Teppo Lampela, Hanne and Jukka Appelqvist, Riina Arkila, Lauren Hakala and Henrikki Harsu as well as Eija Viitala, Petra Laine, and Marja Sutela! I also thank my friends in the chamber choir Kampin Laulu for sharing the passion for choir music and for living out this passion with me, offering refreshing challenges outside the office.

My parents Anna-Maija and Lauri Julin are thanked for always loving me and believing in me. My sisters Annu and Ulla Julin and my nephews Emilio and Antonio as well as my brother-in-law Jussi Sarvikivi are thanked for their friendship and for bringing joy into my life. My parents-in-law Marja-Leena and Kalevi Sarvikivi are 
warmly thanked for their continuous support, interest in my work, and for endless babysitting. Our au pairs Petra, Nicola, Stefanie, and Sonja are also thanked for taking good care of the children and for making the daily life easier for me.

Finally, I owe my heartfelt thanks to my beloved husband Janne for his unconditional love and invaluable support during this project. I also want to express my love to our dearest children Henrik, Axel, and Elsa, who bring so much joy and happiness into my life every day and have showed me the true meaning of life.

Helsinki, March 2008

Emmi Sarvikivi 


\section{REFERENCES}

1. Burke JP. Infection control - a problem for patient safety. $\mathrm{N}$ Engl $\mathrm{J}$ Med. 2003;348(7):651-6.

2. Weinstein RA. Nosocomial infection update. Emerg Infect Dis. 1998;4(3):416-20.

3. Klevens RM, Edwards JR, Richards CL, Jr., Horan TC, Gaynes RP, Pollock DA, et al. Estimating health care-associated infections and deaths in U.S. hospitals, 2002. Public Health Rep. 2007;122(2):160-6.

4. Jarvis WR. Controlling healthcare-associated infections: the role of infection control and antimicrobial use practices. Semin Pediatr Infect Dis. 2004;15(1):30-40.

5. Sohn AH, Garrett DO, Sinkowitz-Cochran RL, Grohskopf LA, Levine GL, Stover BH, et al. Prevalence of nosocomial infections in neonatal intensive care unit patients: Results from the first national point-prevalence survey. J Pediatr. 2001;139(6):821-7.

6. van der Zwet WC, Kaiser AM, van Elburg RM, Berkhof J, Fetter WP, Parlevliet GA, et al. Nosocomial infections in a Dutch neonatal intensive care unit: surveillance study with definitions for infection specifically adapted for neonates. J Hosp Infect. 2005;61(4):300-11.

7. Richards MJ, Edwards JR, Culver DH, Gaynes RP. Nosocomial infections in pediatric intensive care units in the United States. National Nosocomial Infections Surveillance System. Pediatrics. 1999;103(4):e39.

8. Urrea M, Pons M, Serra M, Latorre C, Palomeque A. Prospective incidence study of nosocomial infections in a pediatric intensive care unit. Pediatr Infect Dis J. 2003;22(6):490-4.

9. Fanaroff AA, Korones SB, Wright LL, Verter J, Poland RL, Bauer CR, et al. Incidence, presenting features, risk factors and significance of late onset septicemia in very low birth weight infants. The National Institute of Child Health and Human Development Neonatal Research Network. Pediatr Infect Dis J. 1998;17(7):593-8.

10. Stoll BJ, Hansen N, Fanaroff AA, Wright LL, Carlo WA, Ehrenkranz RA, et al. Lateonset sepsis in very low birth weight neonates: the experience of the NICHD Neonatal Research Network. Pediatrics. 2002;110(2 Pt 1):285-91.

11. Auriti C, Maccallini A, Di Liso G, Di Ciommo V, Ronchetti MP, Orzalesi M. Risk factors for nosocomial infections in a neonatal intensive-care unit. $\mathrm{J}$ Hosp Infect. 2003;53(1):25-30.

12. Stoll BJ, Hansen NI, Adams-Chapman I, Fanaroff AA, Hintz SR, Vohr B, et al. Neurodevelopmental and growth impairment among extremely low-birth-weight infants with neonatal infection. JAMA. 2004;292(19):2357-65.

13. Mahieu LM, Buitenweg N, Beutels P, De Dooy JJ. Additional hospital stay and charges due to hospital-acquired infections in a neonatal intensive care unit. J Hosp Infect. 2001;47(3):223-9. 
14. Smith PB, Morgan J, Benjamin JD, Fridkin SK, Sanza LT, Harrison LH, et al. Excess costs of hospital care associated with neonatal candidemia. Pediatr Infect Dis J. 2007;26(3):197-200.

15. Elward AM, Hollenbeak CS, Warren DK, Fraser VJ. Attributable cost of nosocomial primary bloodstream infection in pediatric intensive care unit patients. Pediatrics. 2005;115(4):868-72.

16. Slonim AD, Kurtines HC, Sprague BM, Singh N. The costs associated with nosocomial bloodstream infections in the pediatric intensive care unit. Pediatr Crit Care Med. 2001;2(2):170-4.

17. Mangram AJ, Horan TC, Pearson ML, Silver LC, Jarvis WR. Guideline for prevention of surgical site infection, 1999. Hospital Infection Control Practices Advisory Committee. Infect Control Hosp Epidemiol. 1999;20(4):250-78; quiz 79-80.

18. Harrington G, Russo P, Spelman D, Borrell S, Watson K, Barr W, et al. Surgical-site infection rates and risk factor analysis in coronary artery bypass graft surgery. Infect Control Hosp Epidemiol. 2004;25(6):472-46.

19. Finkelstein R, Rabino G, Mashiah T, Bar-El Y, Adler Z, Kertzman V, et al. Surgical site infection rates following cardiac surgery: the impact of a 6-year infection control program. Am J Infect Control. 2005;33(8):450-4.

20. Allpress AL, Rosenthal GL, Goodrich KM, Lupinetti FM, Zerr DM. Risk factors for surgical site infections after pediatric cardiovascular surgery. Pediatr Infect Dis J. 2004;23(3):231-4.

21. Nateghian A, Taylor G, Robinson JL. Risk factors for surgical site infections following open-heart surgery in a Canadian pediatric population. Am J Infect Control. 2004;32(7):397-401.

22. Mehta PA, Cunningham CK, Colella CB, Alferis G, Weiner LB. Risk factors for sternal wound and other infections in pediatric cardiac surgery patients. Pediatr Infect Dis J. 2000;19(10):1000-4.

23. Valera M, Scolfaro C, Cappello N, Gramaglia E, Grassitelli S, Abbate MT, et al. Nosocomial infections in pediatric cardiac surgery, Italy. Infect Control Hosp Epidemiol. 2001;22(12):771-75.

24. Levy I, Ovadia B, Erez E, Rinat S, Ashkenazi S, Birk E, et al. Nosocomial infections after cardiac surgery in infants and children: incidence and risk factors. J Hosp Infect. 2003;53(2):111-16.

25. Beck-Sague C, Soto-Cacres V, Jarvis WR. Outbreak investigations. In: Lautenbach E, Woeltje K, editors. Practical Handbook for Healthcare Epidemiologists. 2 ed. Thorofare, NJ: Slack Incorporated; 2004. p. 99-110.

26. Gastmeier P, Loui A, Stamm-Balderjahn S, Hansen S, Zuschneid I, Sohr D, et al. Outbreaks in neonatal intensive care units - they are not like others. Am J Infect Control. 2007;35(3):172-6.

27. Jarvis WR. Investigation of outbreaks. In: Mayhall CG, editor. Hospital Epidemiology and Infection Control. 3 ed. Philadelphia, PA: Lippincott Williams \& Wilkins; 2004. p. $107-22$. 
28. Perl TM, Pottinger JM, Herwaldt LA. Basics of surveillance: an overview. In: Lautenbach E, Woeltje K, editors. Practical Handbook for Epidemiologists. 2nd ed. Thorofare, NJ: SLACK Incorporated; 2004. p. 45-68.

29. Harbarth S, Sax H, Gastmeier P. The preventable proportion of nosocomial infections: an overview of published reports. J Hosp Infect. 2003;54(4):258-66; quiz 321.

30. Gastmeier P. Nosocomial infection surveillance and control policies. Curr Opin Infect Dis. 2004;17(4):295-301.

31. Gastmeier P, Geffers C. Prevention of catheter-related bloodstream infections: analysis of studies published between 2002 and 2005. J Hosp Infect. 2006;64(4):326-35.

32. Widmer AF, Sax H, Pittet D. Infection control and hospital epidemiology outside the United States. Infect Control Hosp Epidemiol. 1999;20(1):17-21.

33. Brachman PS. Epidemiology of nosocomial infections. In: Brachman PS, Bennett E, editors. Hospital infections. 4 ed. Philadelphia, PA: Little, Brown and Company; 1998. p. 3-16.

34. Ellenberg E. Nosocomial infection: a terminological clarification. Lancet Infect Dis. 2004;4(12):721.

35. Garner JS, Jarvis WR, Emori TG, Horan TC, Hughes JM. CDC definitions for nosocomial infections. In: Olmsted RN, editor. APIC Infection Control and Applied Epidemiology: Principles and Practice. St. Louis: Mosby; 1996. p. A-1-A-20.

36. Jarvis WR. The epidemiology of colonization. Infect Control Hosp Epidemiol. 1996; 17(1):47-52.

37. Archibald LK, Hierholzer WJ. Principles of infectious diseases epidemiology. In: Mayhall CG, editor. Hospital Epidemiology and Infection Control. Philadelphia: Lippincott Williams \& Wilkins; 2004. p. 3-17.

38. Jarvis WR. Epidemiology of nosocomial infections in pediatric patients. Pediatr Infect Dis J. 1987;6(4):344-51.

39. Hedin G. Staphylococcus epidermidis--hospital epidemiology and the detection of methicillin resistance. Scand J Infect Dis. 1993;90(Suppl):1-59.

40. Moore DL. Nosocomial infections in newborn nurseries and neonatal intensive care units. In: Mayhall CG, editor. Hospital Epidemiology and Infection Control. Philadelphia: Lippincott Williams \& Wilkins; 1999. p. 665-95.

41. Emori TG, Gaynes RP. An overview of nosocomial infections, including the role of the microbiology laboratory. Clin Microbiol Rev. 1993;6(4):428-42.

42. Lyytikäinen O, Kanerva M, Agthe N, Möttönen T. Sairaalainfektioiden esiintyvyys Suomessa 2005. Suom Lääkäril. 2005(33):3119-23.

43. Ford-Jones EL, Mindorff CM, Langley JM, Allen U, Navas L, Patrick ML, et al. Epidemiologic study of 4684 hospital-acquired infections in pediatric patients. Pediatr Infect Dis J. 1989;8(10):668-75.

44. Raymond J, Aujard Y. Nosocomial infections in pediatric patients: a European, multicenter prospective study. European Study Group. Infect Control Hosp Epidemiol. 2000;21(4):260-23. 
45. Gastmeier P, Kampf G, Wischnewski N, Schumacher M, Daschner F, Ruden H. Importance of the surveillance method: national prevalence studies on nosocomial infections and the limits of comparison. Infect Control Hosp Epidemiol. 1998;19(9):661-7.

46. Harris JA. Pediatric nosocomial infections: children are not little adults. Infect Control Hosp Epidemiol. 1997;18(11):739-42.

47. Gelber SE, Ratner AJ. Hospital-acquired viral pathogens in the neonatal intensive care unit. Semin Perinatol. 2002;26(5):346-56.

48. Goldmann DA. Epidemiology and prevention of pediatric viral respiratory infections in health-care institutions. Emerg Infect Dis. 2001;7(2):249-53.

49. Karanfil LV, Conlon M, Lykens K, Masters CF, Forman M, Griffith ME, et al. Reducing the rate of nosocomially transmitted respiratory syncytial virus. Am J Infect Control. 1999;27(2):91-6.

50. French GL, Cheng AF. Measurement of the costs of hospital infection by prevalence surveys. J Hosp Infect. 1991;18 Suppl A:65-72.

51. Sheng WH, Wang JT, Lu DC, Chie WC, Chen YC, Chang SC. Comparative impact of hospital-acquired infections on medical costs, length of hospital stay and outcome between community hospitals and medical centres. J Hosp Infect. 2005;59(3):205-14.

52. Cavalcante SS, Mota E, Silva LR, Teixeira LF, Cavalcante LB. Risk factors for developing nosocomial infections among pediatric patients. Pediatr Infect Dis J. 2006; $25(5): 438-45$.

53. Frank M, Gur E, Givon-Lavi N, Peled N, Dagan R, Leibovitz E. Nosocomial bloodstream infections in children and adolescents in southern Israel: a 10-year prospective study (1992-2001). Scand J Infect Dis. 2005;37(3):177-83.

54. Wisplinghoff H, Seifert H, Tallent SM, Bischoff T, Wenzel RP, Edmond MB. Nosocomial bloodstream infections in pediatric patients in United States hospitals: epidemiology, clinical features and susceptibilities. Pediatr Infect Dis J. 2003;22(8):686-91.

55. Armenian SH, Singh J, Arrieta AC. Risk factors for mortality resulting from bloodstream infections in a pediatric intensive care unit. Pediatr Infect Dis J. 2005;24(4):309-14.

56. Almuneef MA, Memish ZA, Balkhy HH, Hijazi O, Cunningham G, Francis C. Rate, risk factors and outcomes of catheter-related bloodstream infection in a paediatric intensive care unit in Saudi Arabia. J Hosp Infect. 2006;62(2):207-13.

57. Benjamin DK, DeLong E, Cotten CM, Garges HP, Steinbach WJ, Clark RH. Mortality following blood culture in premature infants: increased with Gram-negative bacteremia and candidemia, but not Gram-positive bacteremia. J Perinatol. 2004;24(3):175-80.

58. Scheckler WE. Hospital costs of nosocomial infections: a prospective three-month study in a community hospital. Infect Control. 1980;1(3):150-2.

59. Haley RW, Schaberg DR, Crossley KB, Von Allmen SD, McGowan JE, Jr. Extra charges and prolongation of stay attributable to nosocomial infections: a prospective interhospital comparison. Am J Med. 1981;70(1):51-8.

60. Halton K, Graves N. Economic evaluation and catheter-related bloodstream infections. Emerg Infect Dis. 2007;13(6):815-23. 
61. Posfay-Barbe KM, Zerr DM, Pittet D. Infection control in paediatrics. Lancet Infect Dis. 2008;8(1):19-31.

62. Marodi L. Neonatal innate immunity to infectious agents. Infect Immun. 2006;74(4):1999-2006.

63. Trivedi HN, HayGlass KT, Gangur V, Allardice JG, Embree JE, Plummer FA. Analysis of neonatal $\mathrm{T}$ cell and antigen presenting cell functions. Hum Immunol. 1997;57(2):69-79.

64. Brady MT. Health care-associated infections in the neonatal intensive care unit. Am J Infect Control. 2005;33(5):268-75.

65. Nambiar S, Singh N. Change in epidemiology of health care-associated infections in a neonatal intensive care unit. Pediatr Infect Dis J. 2002;21(9):839-42.

66. Singh N, Patel KM, Leger MM, Short B, Sprague BM, Kalu N, et al. Risk of resistant infections with Enterobacteriaceae in hospitalized neonates. Pediatr Infect Dis J. 2002;21(11):1029-33.

67. Jalanko $H$, Riikonen $P$, Pihkala U. Immunosuppressoidun lapsen infektiot. In: Ruuskanen O, Peltola H, Vesikari T, editors. Lasten infektiosairaudet. 3rd ed. Tampere: Tampereen yliopiston rokotetutkimuskeskus; 2007. p. 371-80.

68. Hovi L, Saarinen-Pihkala UM, Vettenranta K, Saxen H. Invasive fungal infections in pediatric bone marrow transplant recipients: single center experience of 10 years. Bone Marrow Transplant. 2000;26(9):999-1004.

69. Urrea M, Rives S, Cruz O, Navarro A, Garcia JJ, Estella J. Nosocomial infections among pediatric hematology/oncology patients: results of a prospective incidence study. Am J Infect Control. 2004;32(4):205-8.

70. Simon A, Fleischhack G, Hasan C, Bode U, Engelhart S, Kramer MH. Surveillance for nosocomial and central line-related infections among pediatric hematology-oncology patients. Infect Control Hosp Epidemiol. 2000;21(9):592-6.

71. Burgner D, Dalton D, Hanlon M, Wong M, Kakakios A, Isaacs D. Repeated prevalence surveys of paediatric hospital-acquired infection. J Hosp Infect. 1996;34(3):163-70.

72. Gravel D, Matlow A, Ofner-Agostini M, Loeb M, Johnston L, Bryce E, et al. A point prevalence survey of health care-associated infections in pediatric populations in major Canadian acute care hospitals. Am J Infect Control. 2007;35(3):157-62.

73. Muhlemann K, Franzini C, Aebi C, Berger C, Nadal D, Stahelin J, et al. Prevalence of nosocomial infections in Swiss children's hospitals. Infect Control Hosp Epidemiol. 2004;25(9):765-71.

74. Perlman SE, Saiman L, Larson EL. Risk factors for late-onset health care-associated bloodstream infections in patients in neonatal intensive care units. Am J Infect Control. 2007;35(3):177-82.

75. Aly H, Herson V, Duncan A, Herr J, Bender J, Patel K, et al. Is bloodstream infection preventable among premature infants? A tale of two cities. Pediatrics. 2005; $115(6): 1513-8$.

76. Couto RC, Carvalho EA, Pedrosa TM, Pedroso ER, Neto MC, Biscione FM. A 10-year prospective surveillance of nosocomial infections in neonatal intensive care units. Am J Infect Control. 2007;35(3):183-9. 
77. McGuire W, Clerihew L, Fowlie PW. Infection in the preterm infant. BMJ. 2004;329(7477):1277-80.

78. Stoll BJ, Hansen N, Fanaroff AA, Wright LL, Carlo WA, Ehrenkranz RA, et al. Changes in pathogens causing early-onset sepsis in very-low-birth-weight infants. N Engl J Med. 2002;347(4):240-7.

79. Mahieu LM, De Muynck AO, Ieven MM, De Dooy JJ, Goossens HJ, Van Reempts PJ. Risk factors for central vascular catheter-associated bloodstream infections among patients in a neonatal intensive care unit. J Hosp Infect. 2001;48(2):108-16.

80. Brodie SB, Sands KE, Gray JE, Parker RA, Goldmann DA, Davis RB, et al. Occurrence of nosocomial bloodstream infections in six neonatal intensive care units. Pediatr Infect Dis J. 2000;19(1):56-65.

81. Holmes A, Dore CJ, Saraswatula A, Bamford KB, Richards MS, Coello R, et al. Risk factors and recommendations for rate stratification for surveillance of neonatal healthcare-associated bloodstream infection. J Hosp Infect. 2008;68(1):66-72.

82. Stoll BJ, Temprosa M, Tyson JE, Papile LA, Wright LL, Bauer CR, et al. Dexamethasone therapy increases infection in very low birth weight infants. Pediatrics. 1999; 104(5):e63.

83. Makhoul IR, Bental Y, Weisbrod M, Sujov P, Lusky A, Reichman B, et al. Candidal versus bacterial late-onset sepsis in very low birthweight infants in Israel: a national survey. J Hosp Infect. 2007;65(3):237-43.

84. Pera A, Byun A, Gribar S, Schwartz R, Kumar D, Parimi P. Dexamethasone therapy and Candida sepsis in neonates less than 1250 grams. J Perinatol. 2002;22(3):204-8.

85. Cotten CM, McDonald S, Stoll B, Goldberg RN, Poole K, Benjamin DK, Jr., et al. The association of third-generation cephalosporin use and invasive candidiasis in extremely low birth-weight infants. Pediatrics. 2006;118(2):717-22.

86. Kossoff EH, Buescher ES, Karlowicz MG. Candidemia in a neonatal intensive care unit: trends during fifteen years and clinical features of 111 cases. Pediatr Infect Dis J. 1998; 17(6):504-8.

87. Makhoul IR, Kassis I, Smolkin T, Tamir A, Sujov P. Review of 49 neonates with acquired fungal sepsis: further characterization. Pediatrics. 2001;107(1):61-6.

88. Saiman L, Ludington E, Pfaller M, Rangel-Frausto S, Wiblin RT, Dawson J, et al. Risk factors for candidemia in Neonatal Intensive Care Unit patients. The National Epidemiology of Mycosis Survey study group. Pediatr Infect Dis J. 2000;19(4):319-24.

89. Faix RG, Kovarik SM, Shaw TR, Johnson RV. Mucocutaneous and invasive candidiasis among very low birth weight (less than 1,500 grams) infants in intensive care nurseries: a prospective study. Pediatrics. 1989;83(1):101-7.

90. Huang YC, Lin TY, Leu HS, Peng HL, Wu JH, Chang HY. Outbreak of Candida parapsilosis fungemia in neonatal intensive care units: clinical implications and genotyping analysis. Infection. 1999;27(2):97-102.

91. Kaufman D, Boyle R, Hazen KC, Patrie JT, Robinson M, Donowitz LG. Fluconazole prophylaxis against fungal colonization and infection in preterm infants. $\mathrm{N}$ Engl $\mathrm{J}$ Med. 2001;345(23):1660-166. 
92. Bertini G, Perugi S, Dani C, Filippi L, Pratesi S, Rubaltelli FF. Fluconazole prophylaxis prevents invasive fungal infection in high-risk, very low birth weight infants. J Pediatr. 2005; $147(2): 162-5$.

93. Healy CM, Baker CJ, Zaccaria E, Campbell JR. Impact of fluconazole prophylaxis on incidence and outcome of invasive candidiasis in a neonatal intensive care unit. J Pediatr. 2005; 147(2):166-71.

94. Manzoni P, Stolfi I, Pugni L, Decembrino L, Magnani C, Vetrano G, et al. A multicenter, randomized trial of prophylactic fluconazole in preterm neonates. $\mathrm{N}$ Engl J Med. 2007;356(24):2483-95.

95. Uko S, Soghier LM, Vega M, Marsh J, Reinersman GT, Herring L, et al. Targeted shortterm fluconazole prophylaxis among very low birth weight and extremely low birth weight infants. Pediatrics. 2006;117(4):1243-52.

96. Rangel-Frausto MS, Wiblin T, Blumberg HM, Saiman L, Patterson J, Rinaldi M, et al. National epidemiology of mycoses survey (NEMIS): variations in rates of bloodstream infections due to Candida species in seven surgical intensive care units and six neonatal intensive care units. Clin Infect Dis. 1999;29(2):253-28.

97. MacDonald L, Baker C, Chenoweth C. Risk factors for candidemia in a children's hospital. Clin Infect Dis. 1998;26(3):642-65.

98. Kuhn DM, Mikherjee PK, Clark TA, Pujol C, Chandra J, Hajjeh RA, et al. Candida parapsilosis characterization in an outbreak setting. Emerg Infect Dis. 2004;10(6):1074-81.

99. Kaufman DA, Gurka MJ, Hazen KC, Boyle R, Robinson M, Grossman LB. Patterns of fungal colonization in preterm infants weighing less than 1000 grams at birth. Pediatr Infect Dis J. 2006;25(8):733-7.

100. Manzoni P, Farina D, Leonessa M, d'Oulx EA, Galletto P, Mostert M, et al. Risk factors for progression to invasive fungal infection in preterm neonates with fungal colonization. Pediatrics. 2006;118(6):2359-64.

101. Kicklighter SD, Springer SC, Cox T, Hulsey TC, Turner RB. Fluconazole for prophylaxis against candidal rectal colonization in the very low birth weight infant. Pediatrics. 2001;107(2):293-8.

102. Manzoni P, Arisio R, Mostert M, Leonessa M, Farina D, Latino MA, et al. Prophylactic fluconazole is effective in preventing fungal colonization and fungal systemic infections in preterm neonates: a single-center, 6-year, retrospective cohort study. Pediatrics. 2006; $117(1):$ e22-32.

103. McCrossan BA, McHenry E, O'Neill F, Ong G, Sweet DG. Selective fluconazole prophylaxis in high-risk babies to reduce invasive fungal infection. Arch Dis Child Fetal Neonatal Ed. 2007;92(6):F454-8.

104. Brion LP, Uko SE, Goldman DL. Risk of resistance associated with fluconazole prophylaxis: systematic review. J Infect. 2007;54(6):521-9.

105. Jarvis WR. Selected aspects of the socioeconomic impact of nosocomial infections: morbidity, mortality, cost, and prevention. Infect Control Hosp Epidemiol. 1996;17(8):552-7. 
106. Campins M, Vaque J, Rossello J, Salcedo S, Duran M, Monge V, et al. Nosocomial infections in pediatric patients: a prevalence study in Spanish hospitals. EPINE Working Group. Am J Infect Control. 1993;21(2):58-63.

107. Grohskopf LA, Sinkowitz-Cochran RL, Garrett DO, Sohn AH, Levine GL, Siegel JD, et al. A national point-prevalence survey of pediatric intensive care unit-acquired infections in the United States. J Pediatr. 2002;140(4):432-8.

108. Wong ES. Surgical site infections. In: Mayhall CG, editor. Hospital Epidemiology and Infection Control. Philadelphia: Lippincott Williams \& Wilkins; 1999. p. 189-210.

109. Sairanen H, Pesonen E, Wallgren EI. The outcome of child with congenital heart disease. Duodecim. 1997;113(7):666-74.

110. Consensus paper on the surveillance of surgical wound infections. The Society for Hospital Epidemiology of America; The Association for Practitioners in Infection Control; The Centers for Disease Control; The Surgical Infection Society. Infect Control Hosp Epidemiol. 1992;13(10):599-605.

111. Gaynes RP, Culver DH, Horan TC, Edwards JR, Richards C, Tolson JS. Surgical site infection (SSI) rates in the United States, 1992-1998: the National Nosocomial Infections Surveillance System basic SSI risk index. Clin Infect Dis. 2001;33 Suppl 2:S69-77.

112. Casanova JF, Herruzo R, Diez J. Risk factors for surgical site infection in children. Infect Control Hosp Epidemiol. 2006;27(7):709-15.

113. Kagen J, Bilker WB, Lautenbach E, Bell LM, Coffin SE, St John KH, et al. Risk adjustment for surgical site infection after median sternotomy in children. Infect Control Hosp Epidemiol. 2007;28(4):398-405.

114. Roy MC, Herwaldt LA, Embrey R, Kuhns K, Wenzel RP, Perl TM. Does the Centers for Disease Control's NNIS system risk index stratify patients undergoing cardiothoracic operations by their risk of surgical-site infection? Infect Control Hosp Epidemiol. 2000;21(3):186-90.

115. Holzmann-Pazgal G, Hopkins-Broyles D, Recktenwald A, Hohrein M, Kieffer P, Huddleston $\mathrm{C}$, et al. Case-control study of pediatric cardiothoracic surgical site infections. Infect Control Hosp Epidemiol. 2008;29(1):76-9.

116. Beck-Sague C, Jarvis WR, Martone WJ. Outbreak investigations. Infect Control Hosp Epidemiol. 1997;18(2):138-45.

117. Wenzel RP, Thompson RL, Landry SM, Russell BS, Miller PJ, Ponce de Leon S, et al. Hospital-acquired infections in intensive care unit patients: an overview with emphasis on epidemics. Infect Control. 1983;4(5):371-5.

118. Reingold AL. Outbreak investigations--a perspective. Emerg Infect Dis. 1998;4(1):21-7.

119. Gastmeier P, Stamm-Balderjahn S, Hansen S, Nitzschke-Tiemann F, Zuschneid I, Groneberg K, et al. How outbreaks can contribute to prevention of nosocomial infection: analysis of 1,022 outbreaks. Infect Control Hosp Epidemiol. 2005;26(4):357-61.

120. Gastmeier P, Stamm-Balderjahn S, Hansen S, Zuschneid I, Sohr D, Behnke M, et al. Where should one search when confronted with outbreaks of nosocomial infection? Am J Infect Control. 2006;34(9):603-5. 
121. Friedland IR, Funk E, Khoosal M, Klugman KP. Increased resistance to amikacin in a neonatal unit following intensive amikacin usage. Antimicrob Agents Chemother. 1992;36(8):1596-600.

122. Miranda G, Kelly C, Solorzano F, Leanos B, Coria R, Patterson JE. Use of pulsed-field gel electrophoresis typing to study an outbreak of infection due to Serratia marcescens in a neonatal intensive care unit. J Clin Microbiol. 1996;34(12):3138-41.

123. Archibald LK, Corl A, Shah B, Schulte M, Arduino MJ, Aguero S, et al. Serratia marcescens outbreak associated with extrinsic contamination of $1 \%$ chlorxylenol soap. Infect Control Hosp Epidemiol. 1997;18(10):704-9.

124. van Ogtrop ML, van Zoeren-Grobben D, Verbakel-Salomons EM, van Boven CP. Serratia marcescens infections in neonatal departments: description of an outbreak and review of the literature. J Hosp Infect. 1997;36(2):95-103.

125. Campbell JR, Zaccaria E, Mason EO, Jr., Baker CJ. Epidemiological analysis defining concurrent outbreaks of Serratia marcescens and methicillin-resistant Staphylococcus aureus in a neonatal intensive-care unit. Infect Control Hosp Epidemiol. 1998; $19(12): 924-8$.

126. Hoyen C, Rice L, Conte S, Jacobs MR, Walsh-Sukys M, Toltzis P. Use of real time pulsed field gel electrophoresis to guide interventions during a nursery outbreak of Serratia marcescens infection. Pediatr Infect Dis J. 1999;18(4):357-60.

127. Von Dolinger Brito D, Matos C, Abdalla VV, Da F, Pinto Gontijo PF. An outbreak of nosocomial infection caused by ESBLs producing Serratia marcescens in a Brazilian neonatal unit. Braz J Infect Dis. 1999;3(4):149-55.

128. Jones BL, Gorman LJ, Simpson J, Curran ET, McNamee S, Lucas C, et al. An outbreak of Serratia marcescens in two neonatal intensive care units. J Hosp Infect. 2000;46(4):314-9.

129. Aygun C, Yigit S, Gur D, Erdem G, Oran O, Tekinalp G, et al. Serratia marcescens: an emerging microorganism in the neonatal intensive care unit. Turk $\mathrm{J}$ Pediatr. 2000;42(3):219-22.

130. Jang TN, Fung CP, Yang TL, Shen SH, Huang CS, Lee SH. Use of pulsed-field gel electrophoresis to investigate an outbreak of Serratia marcescens infection in a neonatal intensive care unit. J Hosp Infect. 2001;48(1):13-9.

131. Prasad GA, Jones PG, Michaels J, Garland JS, Shivpuri CR. Outbreak of Serratia marcescens infection in a neonatal intensive care unit. Infect Control Hosp Epidemiol. 2001;22(5):303-5.

132. Villari P, Crispino M, Salvadori A, Scarcella A. Molecular epidemiology of an outbreak of Serratia marcescens in a neonatal intensive care unit. Infect Control Hosp Epidemiol. 2001;22(10):630-4.

133. Fleisch F, Zimmermann-Baer U, Zbinden R, Bischoff G, Arlettaz R, Waldvogel K, et al. Three consecutive outbreaks of Serratia marcescens in a neonatal intensive care unit. Clin Infect Dis. 2002;34(6):767-73.

134. Assadian O, Berger A, Aspock C, Mustafa S, Kohlhauser C, Hirschl AM. Nosocomial outbreak of Serratia marcescens in a neonatal intensive care unit. Infect Control Hosp Epidemiol. 2002;23(8):457-61. 
135. Uduman SA, Farrukh AS, Nath KNR, H ZMY, A I, D KA, et al. An outbreak of Serratia marcescens infection in a special-care baby unit of a community hospital in United Arab Emirates: the importance of the air conditioner duct as a nosocomial reservoir. J Hosp Infect. 2002(52):175-80.

136. Steppberger K, Walter S, Claros MC, Spencker FB, Kiess W, Rodloff AC, et al. Nosocomial neonatal outbreak of Serratia marcescens--analysis of pathogens by pulsed field gel electrophoresis and polymerase chain reaction. Infection. 2002;30(5):277-81.

137. Miranda-Novales G, Leanos-Miranda B, Diaz-Ramos R, Gonzalez-Tejeda L, PeregrinoBejarano L, Villegas-Silva R, et al. An outbreak due to Serratia marcescens in a neonatal intensive care unit typed by 2-day pulsed field gel electrophoresis protocol. Arch Med Res. 2003;34(3):237-41.

138. Milisavljevic V, Wu F, Larson E, Rubenstein D, Ross B, Drusin LM, et al. Molecular epidemiology of Serratia marcescens outbreaks in two neonatal intensive care units. Infect Control Hosp Epidemiol. 2004;25(9):719-21.

139. Lai KK, Baker SP, Fontecchio SA. Rapid eradication of a cluster of Serratia marcescens in a neonatal intensive care unit: use of epidemiologic chromosome profiling by pulsedfield gel electrophoresis. Infect Control Hosp Epidemiol. 2004;25(9):730-4.

140. Bates CJ, Pearse R. Use of hydrogen peroxide vapour for environmental control during a Serratia outbreak in a neonatal intensive care unit. J Hosp Infect. 2005;61(4):364-6.

141. Cullen MM, Trail A, Robinson M, Keaney M, Chadwick PR. Serratia marcescens outbreak in a neonatal intensive care unit prompting review of decontamination of laryngoscopes. J Hosp Infect. 2005;59(1):68-70.

142. Casolari C, Pecorari M, Fabio G, Cattani S, Venturelli C, Piccinini L, et al. A simultaneous outbreak of Serratia marcescens and Klebsiella pneumoniae in a neonatal intensive care unit. J Hosp Infect. 2005;61(4):312-20.

143. David MD, Weller TM, Lambert P, Fraise AP. An outbreak of Serratia marcescens on the neonatal unit: a tale of two clones. J Hosp Infect. 2006;63(1):27-33.

144. Sherertz RJ, Gledhill KS, Hampton KD, Pfaller MA, Givner LB, Abramson JS, et al. Outbreak of Candida bloodstream infections associated with retrograde medication administration in a neonatal intensive care unit. J Pediatr. 1992;120(3):455-61.

145. Damjanovic V, Connolly CM, van Saene HK, Cooke RW, Corkill JE, van Belkum A, et al. Selective decontamination with nystatin for control of a Candida outbreak in a neonatal intensive care unit. J Hosp Infect. 1993;24(4):245-59.

146. Saxen H, Virtanen M, Carlson P, Hoppu K, Pohjavuori M, Vaara M, et al. Neonatal Candida parapsilosis outbreak with a high case fatality rate. Pediatr Infect Dis J. 1995;14(9):776-81.

147. Welbel SF, McNeil MM, Kuykendall RJ, Lott TJ, Pramanik A, Silberman R, et al. Candida parapsilosis bloodstream infections in neonatal intensive care unit patients: epidemiologic and laboratory confirmation of a common source outbreak. Pediatr Infect Dis J. 1996;15(11):998-1002.

148. Vazquez JA, Boikov D, Boikov SG, Dajani AS. Use of electrophoretic karyotyping in the evaluation of Candida infections in a neonatal intensive-care unit. Infect Control Hosp Epidemiol. 1997;18(1):32-7. 
149. Campbell JR, Zaccaria E, Baker CJ. Systemic candidiasis in extremely low birth weight infants receiving topical petrolatum ointment for skin care: a case-control study. Pediatrics. 2000;105(5):1041-5.

150. Aragao PA, Oshiro IC, Manrique EI, Gomes CC, Matsuo LL, Leone C, et al. Pichia anomala outbreak in a nursery: exogenous source? Pediatr Infect Dis J. 2001;20(9):843-8.

151. Cimiotti JP, Haas J, Saiman L, Larson EL. Impact of staffing on bloodstream infections in the neonatal intensive care unit. Arch Pediatr Adolesc Med. 2006;160(8):832-6.

152. Hugonnet S, Chevrolet JC, Pittet D. The effect of workload on infection risk in critically ill patients. Crit Care Med. 2007;35(1):76-81.

153. Tarnow-Mordi WO, Hau C, Warden A, Shearer AJ. Hospital mortality in relation to staff workload: a 4-year study in an adult intensive-care unit. Lancet. 2000;356(922520417185):185-19.

154. Tucker J, Group UKNSS. Patient volume, staffing, and workload in relation to riskadjusted outcomes in a random stratified sample of UK neonatal intensive care units: a prospective evaluation. Lancet. 2002;359(9301):99-107.

155. Harbarth S, Sudre P, Dharan S, Cadenas M, Pittet D. Outbreak of Enterobacter cloacae related to understaffing, overcrowding, and poor hygiene practices. Infect Control Hosp Epidemiol. 1999;20(9):598-603.

156. Andersen BM, Lindemann R, Bergh K, Nesheim BI, Syversen G, Solheim N, et al. Spread of methicillin-resistant Staphylococcus aureus in a neonatal intensive unit associated with understaffing, overcrowding and mixing of patients. J Hosp Infect. 2002;50(1):18-24.

157. Haley RW, Cushion NB, Tenover FC, Bannerman TL, Dryer D, Ross J, et al. Eradication of endemic methicillin-resistant Staphylococcus aureus infections from a neonatal intensive care unit. J Infect Dis. 1995;171(3):614-24.

158. Foca M, Jakob K, Whittier S, Della Latta P, Factor S, Rubenstein D, et al. Endemic Pseudomonas aeruginosa infection in a neonatal intensive care unit. $\mathrm{N}$ Engl $\mathrm{J}$ Med. 2000;343(10):695-700.

159. Spence K, Tarnow-Mordi W, Duncan G, Jayasuryia N, Elliott J, King J, et al. Measuring nursing workload in neonatal intensive care. J Nurs Manag. 2006;14(3):227-34.

160. Beggs CB, Noakes CJ, Shepherd SJ, Kerr KG, Sleigh PA, Banfield K. The influence of nurse cohorting on hand hygiene effectiveness. Am J Infect Control. 2006;34(10):621-6.

161. Boyce JM, Pittet D, Healthcare Infection Control Practices Advisory Committee. Society for Healthcare Epidemiology of America. Association for Professionals in Infection Control. Infectious Diseases Society of America. Hand Hygiene Task F. Guideline for hand hygiene in health-care settings: recommendations of the Healthcare Infection Control Practices Advisory Committee and the HICPAC/SHEA/APIC/IDSA Hand Hygiene Task Force. Infect Control Hosp Epidemiol. 2002;23(12 Suppl):S3-40.

162. Pittet D. Compliance with hand disinfection and its impact on hospital-acquired infections. J Hosp Infect. 2001;48 Suppl A:S40-6. 
163. Eckmanns T, Bessert J, Behnke M, Gastmeier P, Ruden H. Compliance with antiseptic hand rub use in intensive care units: the Hawthorne effect. Infect Control Hosp Epidemiol. 2006;27(9):931-4.

164. Eckmanns T, Schwab F, Bessert J, Wettstein R, Behnke M, Grundmann H, et al. Hand rub consumption and hand hygiene compliance are not indicators of pathogen transmission in intensive care units. J Hosp Infect. 2006;63(4):406-11.

165. Harbarth S, Pittet D, Grady L, Goldmann DA. Compliance with hand hygiene practice in pediatric intensive care. Pediatr Crit Care Med. 2001;2(4):311-4.

166. Larson E, Kretzer EK. Compliance with handwashing and barrier precautions. J Hosp Infect. 1995;30 Suppl:88-106.

167. Girou E, Chai SH, Oppein F, Legrand P, Ducellier D, Cizeau F, et al. Misuse of gloves: the foundation for poor compliance with hand hygiene and potential for microbial transmission? J Hosp Infect. 2004;57(2):162-9.

168. Bearman GM, Marra AR, Sessler CN, Smith WR, Rosato A, Laplante JK, et al. A controlled trial of universal gloving versus contact precautions for preventing the transmission of multidrug-resistant organisms. Am J Infect Control. 2007;35(10):650-5.

169. Grundmann H, Hahn A, Ehrenstein B, Geiger K, Just H, Daschner FD. Detection of cross-transmission of multiresistant Gram-negative bacilli and Staphylococcus aureus in adult intensive care units by routine typing of clinical isolates. Clin Microbiol Infect. 1999;5(6):355-63.

170. Webster CA, Towner KJ. Use of RAPD-ALF analysis for investigating the frequency of bacterial cross-transmission in an adult intensive care unit. $J$ Hosp Infect. 2000;44(4):254-60.

171. Weist K, Pollege K, Schulz I, Ruden H, Gastmeier P. How many nosocomial infections are associated with cross-transmission? A prospective cohort study in a surgical intensive care unit. Infect Control Hosp Epidemiol. 2002;23(3):127-32.

172. Waters V, Larson E, Wu F, San Gabriel P, Haas J, Cimiotti J, et al. Molecular epidemiology of gram-negative bacilli from infected neonates and health care workers' hands in neonatal intensive care units. Clin Infect Dis. 2004;38(12):1682-7.

173. Grundmann H, Barwolff S, Tami A, Behnke M, Schwab F, Geffers C, et al. How many infections are caused by patient-to-patient transmission in intensive care units? Crit Care Med. 2005;33(5):946-51.

174. Mammina C, Di Carlo P, Cipolla D, Giuffre M, Casuccio A, Di Gaetano V, et al. Surveillance of multidrug-resistant gram-negative bacilli in a neonatal intensive care unit: prominent role of cross transmission. Am J Infect Control. 2007;35(4):222-30.

175. Boyce JM, Kelliher S, Vallande N. Skin irritation and dryness associated with two handhygiene regimens: soap-and-water hand washing versus hand antisepsis with an alcoholic hand gel. Infect Control Hosp Epidemiol. 2000;21(7):442-8.

176. Kramer A, Bernig T, Kampf G. Clinical double-blind trial on the dermal tolerance and user acceptability of six alcohol-based hand disinfectants for hygienic hand disinfection. J Hosp Infect. 2002;51(2):114-20. 
177. Pittet D, Mourouga P, Perneger TV. Compliance with handwashing in a teaching hospital. Infection Control Program. Ann Intern Med. 1999;130(2):126-30.

178. Pittet D. Improving adherence to hand hygiene practice: a multidisciplinary approach. Emerg Infect Dis. 2001;7(2):234-40.

179. Girou E, Loyeau S, Legrand P, Oppein F, Brun-Buisson C. Efficacy of handrubbing with alcohol based solution versus standard handwashing with antiseptic soap: randomised clinical trial. BMJ. 2002;325(7360):362.

180. Trick WE, Vernon MO, Hayes RA, Nathan C, Rice TW, Peterson BJ, et al. Impact of ring wearing on hand contamination and comparison of hand hygiene agents in a hospital. Clin Infect Dis. 2003;36(11):1383-90.

181. Gordin FM, Schultz ME, Huber RA, Gill JA. Reduction in nosocomial transmission of drug-resistant bacteria after introduction of an alcohol-based handrub. Infect Control Hosp Epidemiol. 2005;26(7):650-3.

182. Kennedy AM, Elward AM, Fraser VJ. Survey of knowledge, beliefs, and practices of neonatal intensive care unit healthcare workers regarding nosocomial infections, central venous catheter care, and hand hygiene. Infect Control Hosp Epidemiol. 2004;25(9):747-52.

183. Kilbride HW, Wirtschafter DD, Powers RJ, Sheehan MB. Implementation of evidencebased potentially better practices to decrease nosocomial infections. Pediatrics. 2003;111(4 Pt 2):e519-33.

184. Raskind $\mathrm{CH}$, Worley S, Vinski J, Goldfarb J. Hand hygiene compliance rates after an educational intervention in a neonatal intensive care unit. Infect Control Hosp Epidemiol. 2007;28(9):1096-8.

185. Pessoa-Silva CL, Hugonnet S, Pfister R, Touveneau S, Dharan S, Posfay-Barbe K, et al. Reduction of health care associated infection risk in neonates by successful hand hygiene promotion. Pediatrics. 2007;120(2):e382-90.

186. Mayo E. The social problems of an industrial civilization; with an appendix on The political problem. London: Routledge \& Kegan Paul; 1949.

187. Parry GJ, Tucker JS, Tarnow-Mordi WO, Group UKNSS. Relationship between probable nosocomial bacteraemia and organisational and structural factors in UK neonatal intensive care units. Qual Saf Health Care. 2005;14(4):264-9.

188. Sax H, Uckay I, Richet H, Allegranzi B, Pittet D. Determinants of good adherence to hand hygiene among healthcare workers who have extensive exposure to hand hygiene campaigns. Infect Control Hosp Epidemiol. 2007;28(11):1267-74.

189. Thacker SB, Berkelman RL. Public health surveillance in the United States. Epidemiol Rev. 1988; $10: 164-90$.

190. Meriwether RA. Blueprint for a national public health surveillance system for the $21 \mathrm{st}$ century. J Public Health Manag Pract. 1996;2(4):16-23.

191. Haley RW, Culver DH, White JW, Morgan WM, Emori TG, Munn VP, et al. The efficacy of infection surveillance and control programs in preventing nosocomial infections in US hospitals. Am J Epidemiol. 1985;121(2):182-205.

192. Pottinger JM, Herwaldt LA, Peri TM. Basics of surveillance--an overview. Infect Control Hosp Epidemiol. 1997;18(7):513-27. 
193. Lee TB, Baker OG, Lee JT, Scheckler WE, Steele L, Laxton CE. Recommended practices for surveillance. Association for Professionals in Infection Control and Epidemiology, Inc. Surveillance Initiative working Group. Am J Infect Control. 1998;26(3):277-88.

194. Maas A, Flament P, Pardou A, Deplano A, Dramaix M, Struelens MJ. Central venous catheter-related bacteraemia in critically ill neonates: risk factors and impact of a prevention programme. J Hosp Infect. 1998;40(3):211-24.

195. Horan TC, Gaynes RP. Surveillance of nosocomial infections. In: Mayhall CG, editor. Hospital Epidemiology and Infection Control. Philadelphia: Lippincott Williams \& Wilkins; 2004. p. 1659-702.

196. Nosocomial infection rates for interhospital comparison: limitations and possible solutions. A Report from the National Nosocomial Infections Surveillance (NNIS) System. Infect Control Hosp Epidemiol. 1991;12(10):609-21.

197. Edwards JR, Peterson KD, Andrus ML, Tolson JS, Goulding JS, Dudeck MA, et al. National Healthcare Safety Network (NHSN) Report, data summary for 2006, issued June 2007. Am J Infect Control. 2007;35(5):290-301.

198. Edmond MB, Wenzel RP. National and international surveillance systems for nosocomial infections. In: Wenzel RP, editor. Prevention and Control of Nosocomial Infections. Philadelphia, PA: Lippincott Williams \& Wilkins; 2003. p. 109-19.

199. Wilson J, Ramboer I, Suetens C, group H-Sw. Hospitals in Europe Link for Infection Control through Surveillance (HELICS). Inter-country comparison of rates of surgical site infection--opportunities and limitations. J Hosp Infect. 2007;65 Suppl 2:165-70.

200. Mertens R, Van Den Berg JM, Fabry J, Jepsen OB. HELICS: a European project to standardise the surveillance of hospital acquired infection, 1994-1995. Euro Surveill. 1996;1(4):28-30.

201. Suetens C, Morales I, Savey A, Palomar M, Hiesmayr M, Lepape A, et al. European surveillance of ICU-acquired infections (HELICS-ICU): methods and main results. J Hosp Infect. 2007;65 Suppl 2:171-3.

202. Gaynes RP. Surveillance of nosocomial infections: a fundamental ingredient for quality. Infect Control Hosp Epidemiol. 1997;18(7):475-8.

203. Gaynes R, Richards C, Edwards J, Emori TG, Horan T, Alonso-Echanove J, et al. Feeding back surveillance data to prevent hospital-acquired infections. Emerg Infect Dis. 2001;7(2):295-8.

204. Wilson AP, Gibbons C, Reeves BC, Hodgson B, Liu M, Plummer D, et al. Surgical wound infection as a performance indicator: Agreement of common definitions of wound infection in 4773 patients. BMJ. 2004;329(7468):720.

205. Mannien J, van den Hof S, Brandt C, Behnke M, Wille JC, Gastmeier P. Comparison of the National Surgical Site Infection surveillance data between The Netherlands and Germany: PREZIES versus KISS. J Hosp Infect. 2007;66(3):224-31.

206. Gastmeier P, Geffers C, Schwab F, Fitzner J, Obladen M, Ruden H. Development of a surveillance system for nosocomial infections: the component for neonatal intensive care units in Germany. J Hosp Infect. 2004;57(2):126-31. 
207. Glenister HM, Taylor LJ, Bartlett CL, Cooke EM, Sedgwick JA, Mackintosh CA. An evaluation of surveillance methods for detecting infections in hospital inpatients. J Hosp Infect. 1993;23(3):229-42.

208. Coello R, Gastmeier P, de Boer AS. Surveillance of hospital-acquired infection in England, Germany, and The Netherlands: will international comparison of rates be possible? Infect Control Hosp Epidemiol. 2001;22(6):393-7.

209. Haley RW, Schaberg DR, McClish DK, Quade D, Crossley KB, Culver DH, et al. The accuracy of retrospective chart review in measuring nosocomial infection rates. Results of validation studies in pilot hospitals. Am J Epidemiol. 1980;111(5):516-33.

210. Wenzel RP, Osterman CA, Hunting KJ, Gwaltney JM, Jr. Hospital-acquired infections. I. Surveillance in a university hospital. Am J Epidemiol. 1976;103(3):251-60.

211. Belio-Blasco C, Torres-Fernandez-Gil MA, Echeverria-Echarri JL, Gomez-Lopez LI. Evaluation of two retrospective active surveillance methods for the detection of nosocomial infection in surgical patients. Infect Control Hosp Epidemiol. 2000;21(1):24-7.

212. Glenister H, Taylor L, Bartlett C, Cooke M, Sedgwick J, Leigh D. An assessment of selective surveillance methods for detecting hospital-acquired infection. Am J Med. 1991;91(3B):121S-4S.

213. Gastmeier P, Brauer H, Hauer T, Schumacher M, Daschner F, Ruden H. How many nosocomial infections are missed if identification is restricted to patients with either microbiology reports or antibiotic administration? Infect Control Hosp Epidemiol. 1999;20(2):124-7.

214. Horan TC, Gaynes RP, Martone WJ, Jarvis WR, Emori TG. CDC definitions of nosocomial surgical site infections, 1992: a modification of CDC definitions of surgical wound infections. Infect Control Hosp Epidemiol. 1992;13(10):606-8.

215. Ehrenkranz NJ, Shultz JM, Richter EL. Recorded criteria as a "gold standard" for sensitivity and specificity estimates of surveillance of nosocomial infection: a novel method to measure job performance. Infect Control Hosp Epidemiol. 1995;16(12):697-702.

216. Archibald LK, Gaynes RP. Hospital-acquired infections in the United States. The importance of interhospital comparisons. Infect Dis Clin North Am. 1997;11(2):245-55.

217. Wilson AP. Postoperative surveillance, registration and classification of wound infection in cardiac surgery--experiences from Great Britain. APMIS. 2007;115(9):996-1000.

218. Fields CL. Outcomes of a postdischarge surveillance system for surgical site infections at a Midwestern regional referral center hospital. Am J Infect Control. 1999;27(2):158-64.

219. Holtz TH, Wenzel RP. Postdischarge surveillance for nosocomial wound infection: a brief review and commentary. Am J Infect Control. 1992;20(4):206-13.

220. Petherick ES, Dalton JE, Moore PJ, Cullum N. Methods for identifying surgical wound infection after discharge from hospital: a systematic review. BMC Infect Dis. 2006;6:170.

221. Culver DH, Horan TC, Gaynes RP, Martone WJ, Jarvis WR, Emori TG, et al. Surgical wound infection rates by wound class, operative procedure, and patient risk index. National Nosocomial Infections Surveillance System. Am J Med. 1991;91(3B):152S-7S.

222. Gastmeier P. European perspective on surveillance. J Hosp Infect. 2007;65 Suppl 2:159-64. 
223. Gastmeier P, Geffers C, Brandt C, Zuschneid I, Sohr D, Schwab F, et al. Effectiveness of a nationwide nosocomial infection surveillance system for reducing nosocomial infections. J Hosp Infect. 2006;64(1):16-22.

224. Schwab F, Geffers C, Barwolff S, Ruden H, Gastmeier P. Reducing neonatal nosocomial bloodstream infections through participation in a national surveillance system. J Hosp Infect. 2007;65(4):319-25.

225. Zuschneid I, Schwab F, Geffers C, Ruden H, Gastmeier P. Reducing central venous catheter-associated primary bloodstream infections in intensive care units is possible: data from the German nosocomial infection surveillance system. Infect Control Hosp Epidemiol. 2003;24(7):501-5.

226. Bishop-Kurylo D. The clinical experience of continuous quality improvement in the neonatal intensive care unit. J Perinat Neonatal Nurs. 1998;12(1):51-7.

227. Ng SP, Gomez JM, Lim SH, Ho NK. Reduction of nosocomial infection in a neonatal intensive care unit (NICU). Singapore Med J. 1998;39(7):319-23.

228. Horbar JD, Rogowski J, Plsek PE, Delmore P, Edwards WH, Hocker J, et al. Collaborative quality improvement for neonatal intensive care. NIC/Q Project Investigators of the Vermont Oxford Network. Pediatrics. 2001;107(1):14-22.

229. Richards C, Emori TG, Peavy G, Gaynes R. Promoting quality through measurement of performance and response: prevention success stories. Emerg Infect Dis. 2001;7(2):299-301.

230. Jarvis WR. The Lowbury Lecture. The United States approach to strategies in the battle against healthcare-associated infections, 2006: transitioning from benchmarking to zero tolerance and clinician accountability. J Hosp Infect. 2007;65 Suppl 2:3-9.

231. McKibben L, Fowler G, Horan T, Brennan PJ. Ensuring rational public reporting systems for health care-associated infections: systematic literature review and evaluation recommendations. Am J Infect Control. 2006;34(3):142-9.

232. Braun BI, Kritchevsky SB, Wong ES, Solomon SL, Steele L, Richards CL, et al. Preventing central venous catheter-associated primary bloodstream infections: characteristics of practices among hospitals participating in the Evaluation of Processes and Indicators in Infection Control (EPIC) study. Infect Control Hosp Epidemiol. 2003;24(12):926-35.

233. Emori TG, Edwards JR, Culver DH, Sartor C, Stroud LA, Gaunt EE, et al. Accuracy of reporting nosocomial infections in intensive-care-unit patients to the National Nosocomial Infections Surveillance System: a pilot study. Infect Control Hosp Epidemiol. 1998;19(5):308-16.

234. McKibben L, Horan T, Tokars JI, Fowler G, Cardo DM, Pearson ML, et al. Guidance on public reporting of healthcare-associated infections: recommendations of the Healthcare Infection Control Practices Advisory Committee. Am J Infect Control. 2005;33(4):217-26.

235. Health Protection Agency. Mandatory Surveillance of Healthcare Associated Infections Report 2006. Report. London: Health Protection Agency; 2006.

236. Salmenlinna S, Lyytikäinen O, Kotilainen P, Scotford R, Siren E, Vuopio-Varkila J. Molecular epidemiology of methicillin-resistant Staphylococcus aureus in Finland. Eur J Clin Microbiol Infect Dis. 2000;19(2):101-7. 
237. Evans EGV, Richardson MD. Medical Mycology: A Practical Approach. Oxford: Oxford University Press; 1989.

238. Enger L, Joly S, Pujol C, Simonson P, Pfaller M, Soll DR. Cloning and characterization of a complex DNA fingerprinting probe for Candida parapsilosis. J Clin Microbiol. 2001;39(2):658-69.

239. Scherer S, Stevens DA. Application of DNA typing methods to epidemiology and taxonomy of Candida species. J Clin Microbiol. 1987;25(4):675-9.

240. Schmid J, Voss E, Soll DR. Computer-assisted methods for assessing strain relatedness in Candida albicans by fingerprinting with the moderately repetitive sequence Ca3. J Clin Microbiol. 1990;28(6):1236-43.

241. Soll DR. The ins and outs of DNA fingerprinting the infectious fungi. Clin Microbiol Rev. 2000;13(2):332-70.

242. National Committee for Clinical Laboratory Standards. Reference method for broth dilution testing of yeasts. Approved standard - second edition M27-A2. Wayne, PA: NCCLS. 2002.

243. Nieminen HP, Jokinen EV, Sairanen HI. Late results of pediatric cardiac surgery in Finland: a population-based study with 96\% follow-up. Circulation. 2001;104(5):570-5.

244. Jenkins KJ, Gauvreau K. Center-specific differences in mortality: preliminary analyses using the Risk Adjustment in Congenital Heart Surgery (RACHS-1) method. J Thorac Cardiovasc Surg. 2002;124(1):97-104.

245. Perez-Gonzalez LF, Ruiz-Gonzalez JM, Noyola DE. Nosocomial bacteremia in children: a 15-year experience at a general hospital in Mexico. Infect Control Hosp Epidemiol. 2007;28(4):418-22.

246. Lyytikäinen O, Vuopio-Varkila J, Iivonen J, Kela E, Kuusi M, Ruutu P. Antimicrobial resistance. In: Kela E, Lyytikäinen O, Ruutu P, editors. Infectious Diseases in Finland 1995-2004 (KTL B13/2005). Helsinki: National Public Health Institution; 2005. p. 45-9.

247. Lyytikäinen O, Vuopio-Varkila J, Kela E, Ruutu P. Antimicrobial resistance. In: Kela E, Lyytikäinen O, Ruutu P, editors. Infectious Diseases in Finland 2006 (KTL B13/2007). Helsinki: National Public Health Institution; 2007. p. 28-31.

248. Benjamin DK, Jr., DeLong ER, Steinbach WJ, Cotton CM, Walsh TJ, Clark RH. Empirical therapy for neonatal candidemia in very low birth weight infants. Pediatrics. 2003;112(3):543-57.

249. Clark TA, Slavinski SA, Morgan J, Lott T, Arthington-Skaggs BA, Brandt ME, et al. Epidemiologic and molecular characterization of an outbreak of Candida parapsilosis bloodstream infections in a community hospital. J Clin Microbiol. 2004;42(10):4468-72.

250. Hugonnet S, Harbarth S, Sax H, Duncan RA, Pittet D. Nursing resources: a major determinant of nosocomial infection? Curr Opin Infect Dis. 2004;17(4):329-33.

251. Stone PW, Clarke SP, Cimiotti J, Correa-de-Araujo R. Nurses' working conditions: implications for infectious disease. Emerg Infect Dis. 2004;10(11):1984-9.

252. Waggoner-Fountain LA, Walker MW, Hollis RJ, Pfaller MA, Ferguson JE, 2nd, Wenzel $\mathrm{RP}$, et al. Vertical and horizontal transmission of unique Candida species to premature newborns. Clin Infect Dis. 1996;22(5):803-8. 
253. Hajjeh RA, Sofair AN, Harrison LH, Lyon GM, Arthington-Skaggs BA, Mirza SA, et al. Incidence of bloodstream infections due to Candida species and in vitro susceptibilities of isolates collected from 1998 to 2000 in a population-based active surveillance program. J Clin Microbiol. 2004;42(4):1519-27.

254. Pfaller MA, Diekema DJ, Messer SA, Boyken L, Hollis RJ. Activities of fluconazole and voriconazole against 1,586 recent clinical isolates of Candida species determined by Broth microdilution, disk diffusion, and Etest methods: report from the ARTEMIS Global Antifungal Susceptibility Program, 2001. J Clin Microbiol. 2003;41(4):1440-6.

255. Pfaller MA, Diekema DJ, International Fungal Surveillance Participant G. Twelve years of fluconazole in clinical practice: global trends in species distribution and fluconazole susceptibility of bloodstream isolates of Candida. Clin Microbiol Infect. 2004;10 Suppl $1: 11-23$

256. Hazen KC, Baron EJ, Colombo AL, Girmenia C, Sanchez-Sousa A, del Palacio A, et al. Comparison of the susceptibilities of Candida spp. to fluconazole and voriconazole in a 4-year global evaluation using disk diffusion. J Clin Microbiol. 2003;41(12):5623-32.

257. Nguyen MH, Peacock JE, Jr., Morris AJ, Tanner DC, Nguyen ML, Snydman DR, et al. The changing face of candidemia: emergence of non-Candida albicans species and antifungal resistance. Am J Med. 1996;100(6):617-23.

258. Krcmery V, Huttova M, Mateicka F, Laho L, Jurga L, Ondrusova A, et al. Breakthrough fungaemia in neonates and infants caused by Candida albicans and Candida parapsilosis susceptible to fluconazole in vitro. J Antimicrob Chemother. 2001;48(4):521-55.

259. Shah SS, Kagen J, Lautenbach E, Bilker WB, Matro J, Dominguez TE, et al. Bloodstream infections after median sternotomy at a children's hospital. J Thorac Cardiovasc Surg. 2007;133(2):435-40.

260. Huotari K, Agthe N, Lyytikäinen O. Validation of surgical site infection surveillance in orthopedic procedures. Am J Infect Control. 2007;35(4):216-21.

261. Huotari K, Lyytikäinen O, Virtanen MJ, Hospital Infection Surveillance Team, editors. Reduction of orthopaedic surgical site infections during active surveillance; P-37 Program and abstracts, 24th Annual Meeting of the Scandinavian Society for Antimicrobial Chemotherapy; 2007; Tampere.

262. O'Grady NP, Alexander M, Dellinger EP, Gerberding JL, Heard SO, Maki DG, et al. Guidelines for the prevention of intravascular catheter-related infections. Centers for Disease Control and Prevention. MMWR Recomm Rep. 2002;51(RR-10):1-29.

263. Polderman KH, Girbes AR. Central venous catheter use. Part 2: infectious complications. Intensive Care Med. 2002;28(1):18-28.

264. Borghesi A, Stronati M. Strategies for the prevention of hospital-acquired infections in the neonatal intensive care unit. J Hosp Infect. 2008.

265. Rickard CM, Courtney M, Webster J. Central venous catheters: a survey of ICU practices. J Adv Nurs. 2004;48(3):247-56. 
266. Warren DK, Yokoe DS, Climo MW, Herwaldt LA, Noskin GA, Zuccotti G, et al. Preventing catheter-associated bloodstream infections: a survey of policies for insertion and care of central venous catheters from hospitals in the prevention epicenter program. Infect Control Hosp Epidemiol. 2006;27(1):8-13.

267. Hellsten S, editor. Infektioiden torjunta sairaalassa. 5th ed. Porvoo: Suomen Kuntaliitto; 2005.

268. Terho K. Sairaanhoitajan toiminta keskuslaskimokatetri-infektioiden torjunnassa aikuisten teho-osastoilla Suomessa; Pro gradu -tutkielma. Turku: Turun Yliopisto, Hoitotieteen laitos; 2007.

269. Farr BM. Reasons for noncompliance with infection control guidelines. Infect Control Hosp Epidemiol. 2000;21(6):411-6. 